\title{
Do environmental and economic performance go together? A review of micro-level empirical evidence from the past decade or so.
}

\author{
Antoine Dechezleprêtre, Tomasz Kozluk, Tobias Kruse ${ }^{1}$, Daniel Nachtigall and Alain de Serres
}

\begin{abstract}
This article reviews the empirical literature combining economic and environmental performance data at the micro-level, i.e. firm- or facility-level. The literature has generally found a positive and statistically significant correlation between economic performance, as measured by profitability indicators or stock market returns, and environmental performance, as measured by emissions of pollutants or adoption of international environmental standards. The main reason for this finding seems to be that firms that reduce their material and energy costs experience both better economic performance and lower emissions. Only a small and recent literature analyses the joint causal impact of environmental regulations on environmental and economic performance. Interestingly, this literature shows that environmental regulations tend to improve environmental performance while not weakening economic performance. However, the evidence so far is limited to a handful of environmental regulations that are not extremely stringent, so the result cannot be easily generalized. More research is needed to assess the joint effects of environmental regulations on environmental and economic performance, to explore the heterogeneity of these effects across sectors, countries and types of policies, and to understand which policy designs allow improving environmental quality while not coming at a cost in terms of economic performance of regulated businesses.
\end{abstract}

\section{Introduction}

The emergence of green growth as a new paradigm has come in part in response to the recognition that environmental challenges could not be addressed seriously, or at least not effectively, unless they were fully integrated in the development of comprehensive growth-enhancing policy strategies. Governments have long been concerned with environmental issues but "green" and "growth" objectives and policies were essentially pursued by different ministries and agencies operating for the most part in silos. This has often resulted in policy incoherence and a low degree of effectiveness in the pursuit of environmental objectives. The push for the wider adoption by governments of green growth strategies as a means to better pair the objectives of growth with those of environmental sustainability gained more traction in the aftermath of the global financial crisis. The desire to reduce the negative impact of the crisis in a way that could simultaneously meet environmental and economic objectives created a context more favourable to policymakers being receptive to adopting a green growth approach to economic recovery.

One direct implication of the joint pursuit of economic and environmental objectives in development strategies is the acknowledgement of policy trade-offs and synergies. The existence of trade-offs is predicated on the assumption that the transition to green growth necessarily imposes constraints on the optimal allocation of resources, thereby raising production costs and reducing productivity (conventionally measured). The aggregate costs of pursuing environmental objectives have often been reported in the form of economy-wide GDP losses measured against a business-as-usual scenario whereby output growth is assumed to continue unabated, based on a production process and assumptions that largely ignore the environmental constraints (i.e. both the constraints to reduce pollution externalities and the adverse feedback

\footnotetext{
${ }^{1}$ Tobias Kruse gratefully acknowledges financial support from the Economic and Social Research Council (ESRC) through the Centre for Climate Change Economics and Policy.
} 
effects from environmental degradation on output). One major OECD study looking at the economic impact of climate change mitigation highlighted how the adoption of cost-effective measures coordinated at the international level could limit the size of such costs to a relatively small amount, especially in comparison to the estimated costs arising from climate change-related damages and required adaptation (OECD, 2009).

One strand of literature has gone even further, calling into question the assumption that environmental policies necessarily entail a short-run trade-off by raising production costs and reducing efficiency. The challenge to conventional wisdom has been originally laid-out in a landmark paper by Porter and van der Linde (1995), who have argued that improving a company's environmental performance can lead to better economic or financial performance, and not necessarily to an increase in cost. The authors made the case based on the notion that by pushing firms out of their comfort zones, environmental policies can act as a catalyst for investment in innovation that might not have taken place in the absence of the regulatory constraint. Such investment can result in an improvement in both the environmental and business performance. What became referred to as the Porter hypothesis stimulated a large amount of research, both to provide theoretical underpinnings and to assess whether it can be supported by empirical evidence.

The growing importance of this debate in policy circles has sparked a large empirical literature that analyses the relationship between economic and environmental performance at the level of firms, and assesses the joint impact of environmental regulations on these outcomes. The objective of this paper is to provide an upto-date review of this empirical literature that combines economic and environmental performance data at the micro-level. ${ }^{2}$ In this review, we focus largely on GHG emissions, air pollution and toxic release emissions as environmental performance variables. ${ }^{3}$ For each of the papers surveyed, we discuss the pros and cons of the data used and present the empirical approach taken by the authors. A comprehensive table summarizes these micro-level studies that combine environmental- and economic performance variables ${ }^{4}$. Compared to ex-post analysis based on more aggregated data at sectoral, regional or national level, or to ex-ante Computable General Equilibrium models, analyses based on micro-data have several advantages. Sample sizes are typically much larger, allowing for more precisely estimated effects, smaller biases due to unobserved heterogeneity (for example, through the inclusion of firm-level fixed effects) and exploration of heterogeneous impacts across time or sectors.

More generally, micro databases allow for a more credible identification of the treatment effects of a given regulation by applying the sort of quasi-experimental techniques that are most suited to assessing the causal impacts of environmental policies (List et al., 2003; Greenstone and Gayer, 2009). For example, the European Union Emissions Trading System, which regulates the carbon emissions of around 12000 industrial sites and power generating facilities across Europe, only regulates installations above a certain threshold in terms of production capacity. Therefore, it is possible to construct a control group of unregulated installations the size of which falls just below these administrative thresholds, but which are very similar to regulated installations in terms of all other observable characteristics. With a "treated" and a control group that are statistically identical before the introduction of the regulation, it is possible to identify the causal effect of the policy on regulated entities after the introduction of the regulation.

\footnotetext{
${ }^{2}$ Note that the existing literature predominantly covers evidence from the United States and Western Europe due to greater availability of micro-data in these regions.

3 Regulations targeting e.g. solid waste, water pollution, contaminated sites, biodiversity, or livestock (and associated firm performance along these variables) are therefore not covered.

${ }^{4}$ The inclusion criteria for papers covered in the summary table are that they use both environmental and economic performance variables at the micro-level (i.e. that they use firm- or plant-specific observations for both outcome variables).
} 
Analyses based on micro-datasets also have drawbacks, however. In particular, they are ill-equipped to capture general equilibrium effects. For example, it is not possible, using the sort of quasi-experimental methods mentioned above, to analyse the potential impact of the EU ETS on unregulated firms facing higher energy prices because they purchase electricity from regulated firms.

The paper is organized along two main strands of the literature. The first section reviews the literature that analyses the direction of the correlation between environmental and economic performance at the firm level. The key feature of this literature is that it generally abstracts from the drivers of environmental performance, which could be induced by environmental regulations but could also come from voluntary efforts of companies. Because high environmental performance could be driven by profit-enhancing motivations (for example, improving energy efficiency to reduce input costs), one should not necessarily expect a negative relationship between environmental and economic performance. The second section focuses on the literature that analyses the impact of environmental regulations on environmental outcomes and economic performance, with a focus on papers that simultaneously evaluate the impact of environmental policies on both outcomes. Here, basic economic theory predicts regulations to improve environmental performance while weakening economic performance, but alternative theories related to the Porter hypothesis claim that a different outcome is possible.

\section{Does it really pay to be green? Micro-level evidence on the correlation between environmental and economic performance}

There is a large literature on the relationship between environmental performance and economic performance at the firm level. However, this literature usually focuses on establishing correlations and does not properly address causality, i.e. the vast majority of studies cannot say with confidence whether improvements in firms' environmental performance cause improvements in firms' economic performance. This is an important limitation because good environmental and economic performance could be driven by unobserved factors such as good management practices or the quality of the workforce, in which case the solution to improve both environmental and economic performance could reside in implementing policies in the nonenvironmental domain, for example education policies.

Still, establishing the sign of the correlation between environmental and economic performance at the micro level is interesting in its own right, as it can shed light on the widespread concern that there is a systematic negative relationship between the two. The main upshots from the literature focusing on this issue are summarised in this section. Most of the literature focuses on the energy production and manufacturing sectors, as firms in these sectors tend to be the main source of pollution across countries. In comparison, the services sector is an understudied area.

\subsection{Environmental performance and economic performance: Friends or foes?}

Numerous papers have analysed the correlation between environmental and economic performance and several surveys and meta-analyses are available, including Wagner, 2001; Blanco et al., 2009; Horváthová, 2010; Albertini, 2013; Crifo and Sinclair-Desgagné, 2013; Crifo and Forget, 2015. Different measures of economic performance are used, including return on assets (ROA), return on sales (ROS) and return on equity (ROE). Measures of investors' valuation are also used to express expectations of future profitability (e.g. Tobin's Q). ${ }^{5}$ Environmental performance measures include toxic release inventory (TRI) emissions,

\footnotetext{
${ }^{5}$ Tobin's Q is measured as market capitalization divided by assets. It is a measure to capture investors' valuation of a firm relative to the replacement costs of its assets. Hence, it is used to indicate market expectations of future profitability of the firm. Since it requires a value of firms' market capitalization it can typically only be computed for firms listed on a stock exchange.
} 
greenhouse gas (GHG) emissions, environmental management certification (e.g. ISO 14001) ${ }^{6}$ and the adoption of other international environmental standards.

Overall, the literature surveys conclude that better environmental performance is associated with greater financial performance, although there is some variation in the results across studies. For example, Ambec and Lanoie (2007) survey 12 studies that rely on regression analysis of financial performance on environmental performance across multiple years. Nine studies showed that better environmental performance is associated with better economic performance. Two studies show no impact, while one concluded that a negative relationship exists. Similarly, Horváthová (2010) reports that about 55\% of studies find a positive effect and $15 \%$ of studies find a negative effect. Blanco et al. (2009) focus on manufacturing firms and conclude on a prominent absence of penalty for being green. However, this result is affected by the typology of the firm, the methods utilised for implementing environmental initiatives, the intensity of the abatement efforts and stockholders' valuation of green firms.

Particularly in earlier studies, which use cross-sectional data or pooled regression analysis, it remains unclear whether it 'pays to be green' or whether profitable companies decide to engage in green activities. Telle (2006) illustrates in detail the potential omitted variable problems existing in earlier studies using a sample of Norwegian manufacturing plants. Starting with a pooled regression, controlling for observable plant characteristics such as size or industry, the author confirms results of earlier papers that find a positive association between environmental and economic performance. However, when controlling for timeinvariant unobservable plant characteristics (such as time-invariant quality of management, or employee motivation) using plant fixed effects, the effects become insignificant, meaning that environmental performance is not significantly associated with firms' financial performance. Consequently, the author cautions against premature conclusions based on these early pooled regression analyses. He concludes that future emphasis should be placed on analysing the necessary conditions and the specific industries or plants for which it may pay to be green.

In the following subsections, we examine to what extent heterogeneous findings in the literature are due to actual heterogeneities across samples or are simply a result of using different outcomes and explanatory variables. We categorize studies according to (a) the type of environmental performance variable (e.g. adoption of standards, emissions, pollution abatement investments), (b) the time-horizon of the effect, and (c) the economic performance variable (profitability and investors' expectations of future profitability).

(a) Environmental Performance Variables

\section{Adoption of standards and environmental management systems}

A crude measure of environmental performance is provided by international environmental management standards such as ISO 14001. The implementation of an environmental management standard does not provide information on the actual environmental outcomes, which remain unobserved and may be pure signalling of confounding issues, such as management quality. Moreover, such an indicator is binary: within firms having adopted the standard, it is not possible to rank firms according to their performance, while there is also heterogeneity in the environmental performance of firms not adopting the standard. Bearing these limitations in mind, Hibiki et al. (2003) find that the introduction of the ISO 14001 certification system is associated with a statistically significant increase in the market value by $11 \%$ to $14 \%$, based on a sample of 573 Japanese publicly-listed firms in the manufacturing industry listed at the Tokyo Stock Exchange. A similar finding is reported by Jacobs et al. (2010).

6. ISO 14001 is a standardized environmental performance system that covers many aspects of environmental management such as life-cycle assessment and environmental performance indicators. 
An alternative proxy for environmental performance is the implementation of an environmental management system (EMS) at the firm level. Wagner and Blom (2011) examine nearly 500 firms from the UK and Germany and find that the implementation of an EMS is only positively associated with firms' financial performance for already financially well-performing firms. A negative association exists for financially lesswell performing firms. Yet, a limitation of their approach is that the implementation of the EMS does not provide information on the actual environmental outcomes, which remain unobserved.

\section{Emissions releases: Toxic Releases and greenhouse gases}

Emissions releases can be broadly divided into two types of groups: local pollutants such as toxic releases and waste and global pollutants such as greenhouse gas emissions.

Using toxic release inventories allows for an accurate measurement of environmental performance, and many studies have used this indicator. One of the most cited is by Konar and Cohen (2001), who use a sample of 321 (mostly) manufacturing firms in the S\&P 500 and relate the market value to toxic chemicals emitted relative to the firm's revenue. After controlling for variables traditionally thought to explain firm-level financial performance (market share of the firm, industry concentration ratio, sales growth, advertising intensity, research and development intensity, firm size, and the import intensity in the markets for the firms' products), they find that poor environmental performance - as measured by toxic chemicals emissions - is negatively correlated with the intangible asset value of firms. The average 'intangible liability' for firms in their sample is USD 380 million - approximately $9 \%$ of the replacement value of tangible assets. This shows that legally emitted toxic chemicals have a significant effect on the intangible asset value of publicly traded companies. A $10 \%$ reduction in emissions of toxic chemicals is associated with a USD 34 million increase in market value. The magnitude of this effect varies across industries, with larger losses accruing to the traditionally polluting industries. A similar result is reported by King and Lenox (2001).

Other studies have obtained similar results based on improved methodologies, such as Al-Tuwaijri et al. (2004) who analyse the relationship between environmental and economic performance based on a crosssectional dataset of 198 US firms. They find that better environmental performance is associated with significantly better economic performance. This is consistent with the idea that investors view good environmental performance as an intangible asset. To measure environmental performance, they use the ratio of toxic waste recycled to total toxic waste generated. They measure a firm's economic performance using an industry-adjusted annual return, which is calculated as the change in stock price during the year (adjusted for dividends), scaled by the beginning-of-year stock price minus the industry median return (based on two-digit SIC codes). This annual industry-adjusted stock return thus represents a measure of the firm's current-period economic performance relative to other firms in the same industry (they find a similar result when directly using stock price as a measure of economic performance).

A couple of papers have found evidence of a non-linearity of the relationship between environmental performance and economic performance by adding quadratic terms in their regressions. For example, Fujii et al. (2013) examine the relationship between environmental performance - as measured by chemical emissions relative to sales - and economic performance in Japanese manufacturing firms. ROA, ROS and Capital Turnover (CT) are used as indicators of economic performance. They demonstrate a significant inverted U-shaped relationship between toxic releases and ROA and CT. While Fujii et al (2013) solely analyse manufacturing industries, Trumpp and Guenther (2017) include service industries as well. In a global dataset of 2361 firm-years with 696 unique firms, they find a U-shaped relationship between carbon performance and profitability as well as between waste intensity and profitability. Hence, the level of environmental performance affects the direction of the relationship between the two variables. Trumpp and Guenther (2017) conclude that only after passing an environmental performance threshold it starts to 'pay to be green'. 
While studies using toxic emissions as a measure of environmental performance report a positive relationship between environmental and economic performance, this might not be the case for other environmental outcomes. We might expect heterogeneous effects across pollutants, as investors might value reductions in toxic releases more strongly as they reduce the risk of environmental liabilities and lawsuits and reputational damage to the company. Yet, with the emergence of carbon trading systems and penalties associated with non-compliance with GHG regulations, these effects across pollutants might have converged recently. Few papers look at GHG emissions as an environmental performance indicator, but a notable exception is Fujii et al. (2013) who use $\mathrm{CO}_{2}$ emissions alongside chemical emissions. They show that environmental performance measured by $\mathrm{CO}_{2}$ emissions contributes positively to ROA.

Most papers in this literature rely on secondary data collected through official government surveys or mandatory reporting. An exception is a 2003 OECD survey, which contacted 4188 facility managers from seven OECD countries (Canada, France, Germany, Hungary, Japan, Norway, the United States) (Darnall, 2009). It examines the relationship between self-reported firm-specific environmental performance and selfreported profitability. Environmental performance is measured as a change in environmental impacts per unit of output in the last three years, separately for six environmental impacts: natural resource use, solid waste, waste-water effluent, air pollution, GHG emissions, and overall environmental impact. Financial performance is measured as changes in the facility's profits over the past three years. Furthermore, facility managers were asked to rate the environmental policy stringency to which they were subject. They find a positive relationship between environmental performance and financial performance and observe a negative correlation between facility-specific perception of policy stringency and profits. Yet, a limitation of this approach remains the reliability of the managers' responses, as well as the cross-sectional nature of the study, which does not allow an assessment of the direction of the effect.

\section{Pollution Abatement Investments}

Investments in pollution abatement technologies have been used as a proxy for firms' environmental performance, relying on the assumption that such investments result in actual pollution abatement. One concern of such investments is that they may reduce firms' productivity, particularly when a specific abatement technology is prescribed by an environmental regulation. The empirical evidence finds that pollution abatement investments have not had a strong influence on productivity.

Gray and Shadbegian (2003) and Shadbegian and Gray (2005) find insignificant effects for the relationship between firms' pollution abatement investments and productivity. Gray and Shadbegian (2003) examine 116 US pulp and paper plants between 1979 and 1990 and observe that the effect of pollution abatement investments on productivity differs substantially by plants' technology. On average, they observe that plants with higher abatement costs have lower productivity levels. Yet, this negative relationship between higher abatement costs and lower productivity levels is largely driven by mills, which incorporate a pulping process. For mills without such technology, the impact is negligible. Similarly, Shadbegian and Gray (2005) examine the contribution of pollution abatement expenditure to firms' productivity for 68 paper mills, 55 oil refineries and 27 steel mills. In their sample, they are able to distinguish between productive and pollution abatement expenditures for each production input. They find little evidence that abatement inputs contribute to production with nearly all coefficients being insignificant.

Ayerbe and Gorriz (2001), Broberg et al. (2013), and Sanchez-Vargas et al. (2013) find modest negative relationships between firms' environmental performance and productivity. Ayerbe and Gorriz (2001) examine whether pollution abatement investments designated for compliance with environmental performance- and technology standards impact firms' productivity. In their sample of 53 large Spanish companies, they find a weak negative relationship with firms' productivity. Yet, the authors conclude that this finding might be specific to their small sample and the specific pollution abatement technology. 
Broberg et al (2013) use a stochastic frontier model to estimate the relationship between environmental protection investment and technical efficiency in five Swedish manufacturing industries. Environmental protection investments are again used as a proxy for environmental performance, assuming that such investments result in actual environmental protection. They observe a weak negative relationship between environmental investments and technical efficiency. Sanchez-Vargas et al. (2013) use a 2002 cross-sectional dataset of 900 Mexican manufacturing plants to identify nonlinearities in the relationship between plants' pollution abatement expenditure and productivity. They find an overall negative relationship between pollution abatement expenditure and plants' productivity. However, the relationship is nonlinear and depends on plant size: the negative effect is larger for small plants and nearly negligible for larger ones.

\section{(b) Short-term vs. long-term performance}

An important question in understanding the relationship between environmental and economic performance is whether improving environmental performance induces costs in the short run but benefits in the longer run. A few studies seem to confirm this hypothesis. Khanna and Damon (1999) evaluate the impact of the EPA's 33/50 program on the economic performance of firms in the US chemical industry relative to nonparticipants. The 33/50 Program is a voluntary initiative launched by the EPA in 1991 to encourage firms to reduce their emissions of 17 high-priority toxic chemicals. Of the firms emitting one or more of these 17 chemicals in 1988, 14\% had pledged their participation in the program by 1993 . After controlling for the effects of firm-specific factors, the authors find that an increased probability of participation in the program is statistically significantly associated both with a decline in return on investment and with an increase in market variables (excess of market value over the book value of assets normalized by sales). Therefore, while the immediate impact of participation in the program on profits is negative relative to the profits of nonparticipants, participating companies are expected to be more profitable in the long run, and therefore market variables perform better.

Similarly, Horváthová (2012) distinguishes between short- and longer-run effects. Using a sample of 136 Czech firms observed over several years, she finds that better environmental performance decreases financial performance in the subsequent year, but increases financial performance after two years. The net (cumulative) effect seems to be negative, but the author does not test whether it is statistically significant. The study's indicator of environmental performance is a composite indicator constructed using the European Pollutant Release and Transfer Register (E-PRTR), which provides data on 93 pollutants releases to air, water and land, as well as off-site transfers of waste and of pollutants in waste water from industrial facilities in the European Union Member States. Economic performance is measured using ROA and ROE. Rassier and Earnhart (2011) also focus on the inter-temporal effect of environmental performance on financial performance. They study U.S. firms and measure the environmental performance by permitted wastewater discharge limits and use the returns on sales as the financial performance measure. In contrast to Horváthová (2012), they find that lower emissions levels improve firms' financial performance both in the short and the long run with a stronger effect in the long run.

\section{(c) Profitability and investors' valuation}

The theoretical channels through which environmental performance impacts short-term profitability (ROA, ROE, ROS) are somewhat different from the drivers of investors' valuation of a firm, as measured by Tobin's Q. For the former effect to exist there must be a tangible impact on firms by either increasing their revenue or reducing costs. The latter is driven by investors' expectations of future profitability. It captures how the market values a firm relative to the replacement value of its assets. It is common to observe firms which 
receive a high valuation by investors even though they do not operate profitably over a period of time. Consequently, it is necessary to separate the two channels and we might expect different effects across these variables.

In a series of studies, Rassier and Earnhart (2010a; 2010b; 2015) analyse the extent to which firm-specific limitations on emissions have heterogeneous effects on firms' actual profitability and investors' expectations on firms' future profitability. ${ }^{7}$ Across all studies, they examine the effects of facility-specific wastewater discharge limits regulated by the US EPA. ${ }^{8}$ Although the authors do not observe actual emissions, the enforced facility-specific discharge limits are used as a close proxy for facilities' emissions. ${ }^{9}$ Using ROS as their financial performance measure, Rassier and Earnhart (2010a) use quarterly data on 59 firms and annual data of 73 firms to examine the relationship between financial performance and discharge limits. For both datasets, they find a negative relationship between clean water regulation and firms' actual profitability. A $10 \%$ reduction in the average permitted discharge leads to a decline in the return on sales of between $0.8 \%$ and $2.7 \%$.

In a separate paper, Rassier and Earnhart (2010b) examine the effect of permitted wastewater discharge levels on future expected financial performance of 54 manufacturing firms in the US using annual data. They find that tighter permitted discharge limits significantly decrease the market's expectations of future profits. In a more recent paper, Rassier and Earnhart (2015) build upon their earlier studies and estimate the effects on actual and expected profitability jointly using a sample of 740 observations from 47 unique firms using quarterly data. They are able to improve upon their earlier work by including additional control variables. Their results on actual profitability are consistent with the Porter hypothesis indicating that tighter clean water discharge limits are positively associated with profitability. However, their results on expected profitability suggest that investors appear to expect a negative relationship between clean water discharge limits and profitability. This finding suggests that investors do not value the positive effect of regulation on firms' profitability, but instead seem to expect a negative impact on firms' profitability from tighter regulation. The authors explain these results with behavioural biases and lack of information among investors.

\section{Summing up}

Overall, most studies have focussed on toxic releases or pollution abatement investments and their short-run effects on economic performance variables. This emphasis is at least partly driven by data availability. To observe firms' environmental management systems (EMS) over time, regular industry surveys would be necessary. Firms might also not be willing to share detailed data on their management systems, which limits further analysis on EMS. The lack of long panel data has limited the possibilities to study long-run profitability effects, although more data is becoming available. The most conclusive evidence is found for reductions in toxic release emissions which seem to be positively related with firms' valuation and profitability. Similarly, pollution abatement investments do not seem to hurt firms' productivity. Most of the evidence covers the power generation or the manufacturing sector. Moving beyond these sectors to incorporate service industries remains an important avenue for future research. Similarly, most of the

$7 \quad$ For a comprehensive summary on the differences between the studies see Table C.1 in Rassier and Earnhart (2015).

$8 \quad$ All papers use wastewater discharge limits for biochemical oxygen demand (BOD) and total suspended solids (TSS). These are conventional and highly prevalent pollutants, which receive regulatory scrutiny by the EPA.

The facility-specific discharge limits are based on state-or industry-level water quality standards. These state water quality standards differ across water bodies and time. Moreover, the discharge limits differ across facilities and time since the assimilative capacity of water bodies differs across location and time (Rassier and Earnhart, 2015: 133). 
evidence covers firms located in one or a small group of developed countries. Hence, further work focussing on developing countries is necessary to assess the generalizability of the results.

\subsection{Understanding the drivers: why environmental performance can go hand in hand with economic performance}

The vast literature that has looked empirically at the relationship between environmental and economic performance overall points to a positive correlation. This section tries to understand why such a positive relationship may emerge empirically.

\subsubsection{Theoretical background}

While the conventional wisdom regarding environmental protection is that it comes at an additional cost imposed on firms, which should thus lead to weaker economic performance, this plausible prediction has been challenged over the past two decades following the famous paper by Porter and van der Linde (1995), who argued that improving a company's environmental performance can lead to better economic or financial performance, and not necessarily to an increase in cost. Porter and van der Linde (1995) did not provide any strong theoretical motivation for that prediction, but many authors have subsequently provided theoretical grounding for it.

Ambec and Lanoie (2008) argue that there are at least seven ways in which improving a company's environmental performance can lead to better economic performance (see Figure 1). This could happen through either an increase in revenue or a reduction in production costs. Better environmental performance could lead to an increase in revenues through three channels: (a) better access to certain markets; (b) differentiating products; and (c) selling pollution-control technology. Better environmental performance can lead to a reduction in costs in four categories: (a) risk management and relations with external stakeholders; (b) cost of material, energy, and services; (c) cost of capital; and (d) cost of labour. In the following subsections we present the empirical literature that has analysed these potential determinants of the mostly positive relationship between environmental and economic performance uncovered by studies reviewed in section 2.1. 
Figure 1. Potential positive links between environmental and economic performance

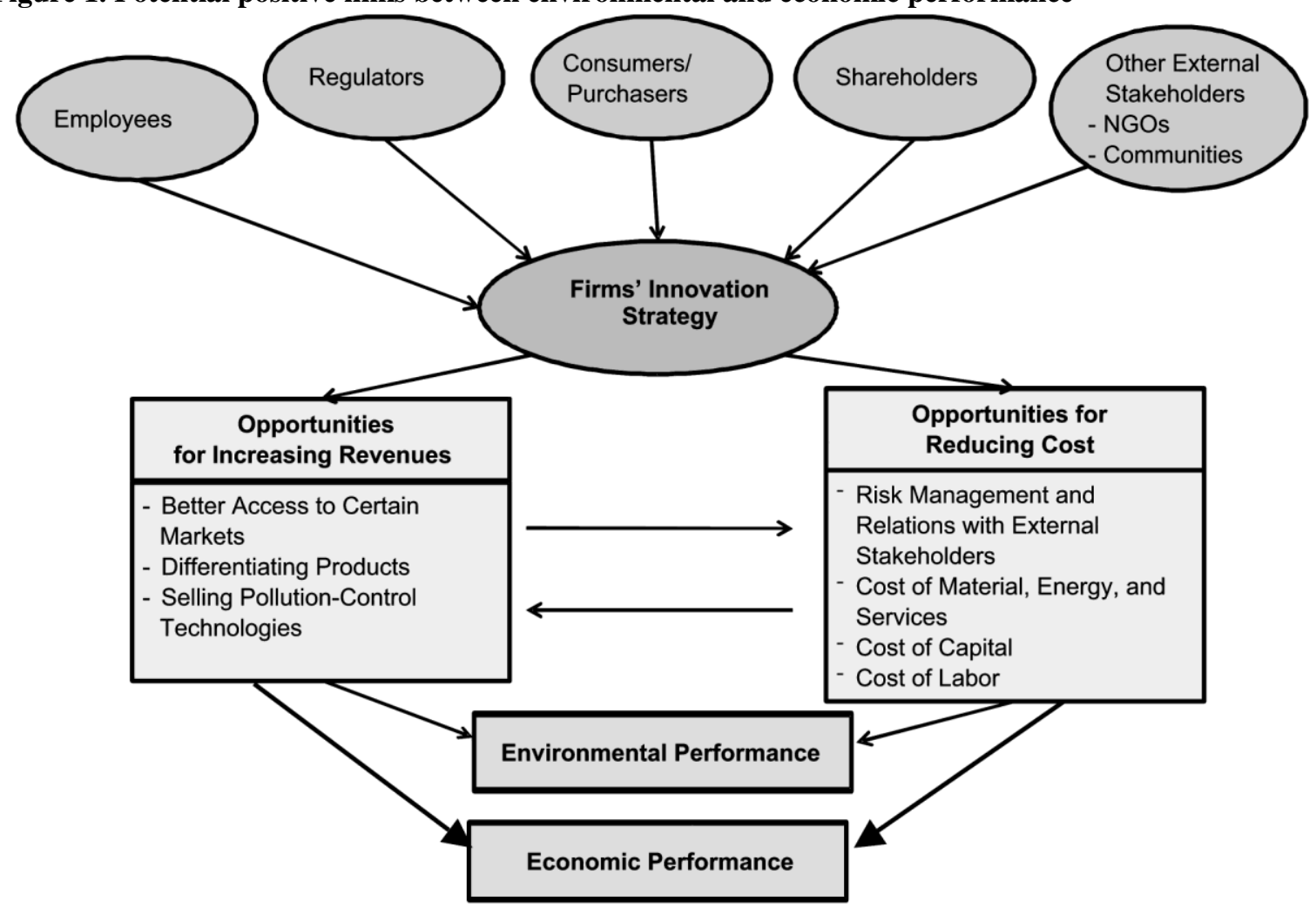

Source: Ambec and Lanoie (2008).

\subsubsection{Better economic performance through increased revenues}

The empirical evidence on environmental performance providing better access to certain markets is usually available from case studies with small samples. An exception is the paper by Antweiler and Harrison (2003), which tests the prediction that 'environmentally-leveraged' firms with consumer market exposure experience larger emission reductions. Indeed, they find that companies that are relatively more exposed to final consumers and that have a greater diversity of emissions across products (thus, are more "environmentallyleveraged") reduce their releases to air and transfers of wastes off site most strongly, but also interestingly increase more less visible releases to subsoil via underground injection. The authors obtain these findings by making use of firms' responses to the publication of Canada's National Pollutant Release Inventory (NPRI) between 1993 and 1999. NPRI covers around 2500 facilities which have to report their emissions of 192 pollutants into the air, water, land, and subsoil. The main problem faced by the authors is that they do not observe purchases from households and businesses at a sufficiently high level of disaggregation and they cannot link products to individual plants. Thus, they rely on the idea that, if consumers use the NPRI to identify facilities with high levels of pollution and to identify the companies that own them, the only way they can then punish these firms is by not buying any products from these firms since they cannot link products to particular facilities. Therefore, multi-product firms will experience a "spillover" effect through which high-emission products will negatively impact sales of low-emission products.

Only a handful of papers analyse the correlation between the introduction of green products and firms' economic performance. This small literature has mostly focused on the relationship between introduction of new green products and employment growth. Rennings and Zwick (2002) and Rennings et al. (2004) examine the determinants of employment changes due to the introduction of new environment-friendly 
products. The data stem from telephone surveys in five European countries. Some 1594 interviews were conducted with environmentally innovative establishments from both the industry and services sectors. The authors classify environmental innovations of these establishments into new products and services, new processes, adoption of end-of-pipe technologies, and enhanced recycling. Based on results of discrete choice models, they show that if the most important environmental innovation is a product or a service innovation, i.e. the introduction of a new green product or service, then this has a positive and statistically significant effect on the probability that the firm increases its number of employees. However, if the most important environmental innovation is an end-of-pipe innovation, this increases the likelihood that the firm decreases its employment base.

While both studies use cross-sectional data, similar results are obtained using a panel dataset (Horbach, 2010). Firms in the environmental sector that developed new or modified products from 2002 to 2003 significantly increased their employment from 2003 to 2005 . Furthermore, the magnitude of the impact of innovation on employment seems to be larger than in non-environmental fields. The empirical analysis is based on the establishment panel of the Institute for Employment Research (Nuremberg) and includes 900 firms operating in environmental sectors and 12,400 firms operating in non-environmental fields. The authors explain that the effect may be more pronounced in environmental fields due to the fact that environmental technologies and products are characterized by an earlier market development phase compared to other innovative products connected with higher employment dynamics.

A recent study conducted by Palmer and Truong (2017) examines the relationship between the introduction of new products based on green technologies and firm profitability. "New technological green products" include any new product that builds on technological advances to limit or lower its environmental footprint or that of other products, for instance, through improved energy efficiency or waste management. While past studies have mostly used survey-based questionnaires to capture firms' new green products, Palmer and Truong (2017) use the press releases of actual new product introductions instead of relying on respondents' reporting which may be less reliable and less objective. The sample consists of 1020 technological green new product introductions (NPIs) emanating from 79 global firms between 2007 and 2012. The authors find a positive correlation between technological green NPIs and firm profitability, as measured by turnover or return on total capital. Since the authors do not control for new product innovations in general, this result could simply reflect the impact of new product innovations in general. However, when the authors use as an alternative explanatory variable the ratio of technological green NPIs to the total number of NPIs, they interestingly still find a positive effect, although only statistically significant at the $10 \%$ level, suggesting that there might be extra profitability associated with a higher proportion of green products. Overall, the findings point to the existence of financial incentives for firms to use green technologies to limit the environmental impact of new product introductions.

\subsubsection{Improved economic performance through reduced cost of inputs}

While there is so far only limited empirical evidence to back the hypothesis that increased environmental performance could be associated with an increase in revenue, or this evidence is based on small samples from which no general conclusion can be made, much more evidence is available on the cost side.

\section{Energy and materials}

Perhaps the most natural way in which better environmental performance could be associated with greater economic performance is through reduced cost of inputs, and in particular of energy. The empirical evidence available confirms this prior. Existing studies examine this question often through measures of firms' productivity (Total Factor Productivity or TFP). This captures the effect on firms' output from the introduction of an environmental regulation with a constant set of production inputs. According to the Porter Hypothesis, regulation may increase productivity, as it reduces firms' wasteful energy inputs. Firms facing 
some costly regulation may also react by improving the productivity of other inputs such as labour. The opposing view is that regulation reduces firms' productivity as it poses additional constraints on their production. Overall, the empirical literature shows that environmental regulations do not appear to be a major driver of firms' productivity.

A number of studies examines the relationship between energy- and emissions-intensity and overall production efficiency. Overall, results are mixed, yet, the most robust studies tend to find positive effects. Using a sample of 68 US paper mills, Shadbegian and Gray (2003) find that plants with lower emissions are also generally more efficient: plants with 10 percent higher productivity have 2.5 percent lower emissions. This indicates that productive efficiency and pollution abatement efficiency are complements, with better managers being better at both production and abatement (rather than substitutes, with managers concentrating on productive efficiency at the expense of their abatement performance). Shadbegian and Gray (2006) also report a positive correlation between production efficiency and pollution abatement efficiency in the US paper, oil and steel industries, even after controlling for observable factors.

Bloom et al. (2010) examine how much the energy intensity of firms (energy costs per unit of output) and total factor productivity correlate with the quality of management, by matching firm-level information on management practices to production and energy usage data from the UK census for the establishments owned by these firms. They find that firms with good management practices are less energy-intensive while being more productive. Thus, lower energy intensity is associated with better economic performance as measured by TFP. In terms of magnitude, improving the quality of management practices from the $25^{\text {th }}$ to the $75^{\text {th }}$ percentile is associated with a $17.4 \%$ reduction in energy intensity and with a $3.7 \%$ increase in TFP. Martin et al. (2012) report a similar result when focusing specifically on management practices related to climate change for 190 randomly selected manufacturing plants in the UK. The authors interviewed the managers of these plants to derive measures for the companies' practices in the areas of energy use and climate change and combined their responses with energy consumption data from the Annual Respondents Database (ARD) and economic performance data from official business microdata. They find that climate-friendly management practices, as measured by an index constructed from survey responses, are associated with lower energy intensity and higher productivity.

Similarly, Horbach and Rennings (2013) show that the introduction of cleaner production process innovations leads to higher employment of firms. Noticeably however, end-of-pipe technologies (in particular air and water process innovations) have a negative impact on employment. This confirms an earlier result by Pfeiffer and Rennings (2001) who show that cleaner production processes are more likely to increase employment compared to end-of-pipe technologies. Van Leeuwen and Mohnen (2017) obtain similar results from a panel of Dutch manufacturing firms for the period 2000-2008. They show that only production process innovations are positively correlated with firms' productivity, whereas end-of-pipe innovations are negatively correlated. Kumar and Managi (2010) also find a positive relationship between environmental and economic performance. They analyse the US emission allowance trading scheme for $\mathrm{SO}_{2}$ emissions, which was introduced as part of the 1990 US Clean Air Act Amendment (USCAAA). Again, as in the case of the EU ETS, participation in the $\mathrm{SO}_{2}$ trading scheme is not a direct measure of environmental performance. However, since these companies face a price on their firm-specific $\mathrm{SO}_{2}$ emissions, they should emit less than in the absence of the trading scheme. They find that between 1995 and 2005 electricitygenerating plants are able to increase electricity output and reduce $\mathrm{SO}_{2}$ emissions due to the allowance trading scheme.

Alongside papers based on regression analysis of past data, a new literature is emerging that uses experimental data to assess the environmental-economic performance of firms. Gosnell et al. (2017) implemented an experiment in partnership with Virgin Atlantic Airlines (VAA) in order to test the impact of various incentives (monitoring, performance information, personal targets, and prosocial incentives) on fuel efficiency of their captains in three key flight areas: pre-flight (aircraft fuel load), in-flight (fuel- 
efficiently between take-off and landing), and post-flight (taxi). They find that, by simply informing the captains that the academic researchers and VAA Fuel Efficiency personnel overseeing the study are measuring their behaviours, captains considerably reduce fuel consumption: captains in this experimental group significantly increased the implementation of Efficient Flight and Efficient Taxi by nearly 50 percent from the pre-experimental period. These behavioural changes generated more than 7700 tons of fuel saved for the airline over the eight-month experimental period (i.e. \$6.1 million in 2014 prices), which translates to approximately 24500 tons of $\mathrm{CO}_{2}$ abated. Moreover, monitoring and targets also induce captains to improve efficiency in all three key flight areas. The study provides the lowest ever calculated marginal abatement cost per ton of $\mathrm{CO}_{2}$, at negative $\$ 250$ (i.e. \$250 savings per ton abated), showing that airlines can improve both environmental as well as economic performance at the same time. Experimental studies of this sort are only emerging, but constitute a fruitful avenue for future research.

\section{Labour costs}

Some authors have also argued that better environmental performance can lead to a reduction in the cost of labour, because environmentally-friendly companies are able to attract and retain motivated employees who work harder for lower wages. Indeed, if people prefer their employer to be socially responsible, they will, if faced with a choice between two otherwise identical job offers with equal pay, choose the employer they find more responsible. Therefore, to make those people indifferent, the less responsible employer must offer a higher wage. There is empirical support for the idea that social responsibility of firms is valued by employees. For example, it has been reported that job satisfaction is substantially higher when top management is perceived as strongly supporting ethical behaviour. Lanfranchi and Pekovic (2012) use data on 11600 employees at 7700 French firms and find that employees of firms that have adopted voluntary environmental standards report a considerably, and statistically significantly, higher feeling of usefulness at work.

Nyborg and Zhang (2013) carried out a survey on 100,000 Norwegian employees and show that firms with higher Corporate Social Responsibility (CSR) pay substantially, and statistically significantly, lower wages. Three studies using data for French firms and employees find that, for firms that have adopted voluntary environmental standards, employees are more likely to work uncompensated overtime hours (Lanfranchi and Pekovic, 2012), labour productivity is higher (Delmas and Pekovic, 2013), and difficulties with recruitment are smaller (Grolleau et al., 2012). It is not clear, however, whether this is driven by self-selection of more productive and motivated employees into CSR firms or whether working for a socially responsible employer in itself increases motivation at work. This literature is still in its infancy and future research might enable to shed light on this issue.

\section{Cost of capital}

Better environmental performance could be associated with a lower cost of capital, in particular because of lower exposition to environmental risk and liabilities. For example, El Ghoul et al. (2011) examine the effect of CSR on the cost of equity capital for a sample of around 2,000 US firms. They find that firms with better CSR scores exhibit cheaper equity financing. Attig et al. (2013) find that credit rating agencies tend to award relatively high ratings to firms with good social performance. Cheng et al. (2013) show that firms with better CSR performance face significantly lower capital constraints. Goss and Roberts (2011) use a sample of 3 996 loans to US firms and find that firms with social responsibility concerns pay between 7 and 18 basis points more than firms that are more responsible. A common limitation to all these studies is that they use indicators of CSR that include not only environmental performance but also other measures of social responsibility, such as responsible practices towards employees. Therefore, it is not possible to determine whether the relationship stems from better environmental performance or better performing or more committed employees. 


\subsection{Summing up}

While numerous measures of environmental performance are used, the measure of economic performance usually applied is financial performance based on market value data. While market data has the advantage of being widely available, it is also - by definition - restricted to listed firms and, as such, the results may be affected by a sample selection bias and might not be representative of the population of firms, in particular of smaller firms that are typically not listed. Moreover, this literature generally abstracts from the drivers of environmental performance, which could come from voluntary efforts of companies or be induced by environmental regulations. Because high environmental performance could be driven by profit-enhancing motivations (for example, improving energy efficiency to reduce input costs), it is perhaps not surprising that many studies report a positive relationship between environmental and economic performance.

Ambec and Lanoie (2008) suggest two main theoretical channels through which environmental performance can impact economic performance positively: (1) increasing revenues or (2) reducing costs of inputs. The empirical evidence on the revenue channel is relatively scarce. This is at least partly due to a lack of sufficiently disaggregated data of new green product introductions at the firm level and suitable control groups to take into account non-green product introductions. Yet, the existing studies suggest that a positive association may exist between environmental and economic performance through an increase in revenue. More evidence is available on the cost side: The cost channel suggests that environmental performance can improve economic performance by reducing costs of inputs. Overall, the empirical evidence finds support for this channel. The majority of studies focused on energy- and material inputs for which a positive relationship is observed. Yet, the effect seems to be limited to cleaner production process innovations. For end-of-pipe innovations, which maintain the same production process but reduce emissions through installing additional filters, most studies do not find a positive effect on economic performance. In addition, the results of some papers suggest that firms with better environmental performance also have lower costs of labour and have access to cheaper equity financing.

\section{The separate impact of environmental policies on economic outcomes and environmental performance}

Positive economic and environmental outcomes can go hand in hand, particularly when environmental performance is aligned with a firm's profit-enhancing strategy such as investments in energy or material efficiency to reduce costs. While this suggests that firms might benefit from better environmental performance in economic terms, it does not imply that (exogenous) environmental regulations aiming at improving firms' environmental performance would improve firms' economic outcomes.

Environmental regulations are accused by some of jeopardising economic activity but are viewed by others as potential drivers of economic growth. Economists traditionally think of environmental regulations as adding costs to companies and slowing down productivity, because they divert resources away from productive investments such as investments in research and development and towards pollution-control activities (Rose, 1983; Schmalensee, 1993; Walley and Whitehead, 1994; Jaffe et al., 1995). Since it is reasonable to assume that firms would have reduced pollution in the absence of environmental regulation if it was profitable for them to do so, any environmental regulation is likely to come at a cost for businesses. If the stringency of policies differs across countries or regions, then environmental regulations may not only add costs to businesses, but may also affect the competitiveness of the domestic industry, putting some companies at a competitive disadvantage vis-à-vis their foreign competitors (Levinson and Taylor, 2008). Debates about the impacts of environmental regulations on competitiveness are often framed in terms of 
'jobs versus the environment' (Morgenstern et al., 2002), particularly in countries and regions where declining manufacturing employment has become a contentious political issue. ${ }^{10}$

However, a different view of the world has been articulated since the 1990s, with what has become widely known as the Porter hypothesis (Porter, 1991; Porter and van der Linde, 1995). The basic idea is that environmental regulations should foster innovation in environmentally-friendly technologies which would not have been developed otherwise, and the adoption of these new technologies could well, in the medium run, improve firms' productivity or allow regulated firms to achieve technological leadership.

Ambec et al. (2013) illustrate the main causal links involved in the Porter Hypothesis (see Figure 2). If an environmental regulation is well-designed and sufficiently flexible, it may not only lead to improved environmental performance, but it may also lead to innovation offsets. These offsets can partially, or sometimes more than fully, offset any additional costs from the regulation, thereby increasing firms' business performance. Thus, according to the Porter Hypothesis, while effective environmental regulation improves the environmental performance of firms, well-designed regulation could also improve business performance.

Figure 2. Causal links involved in the Porter Hypothesis (Source: Ambec et al. 2013)

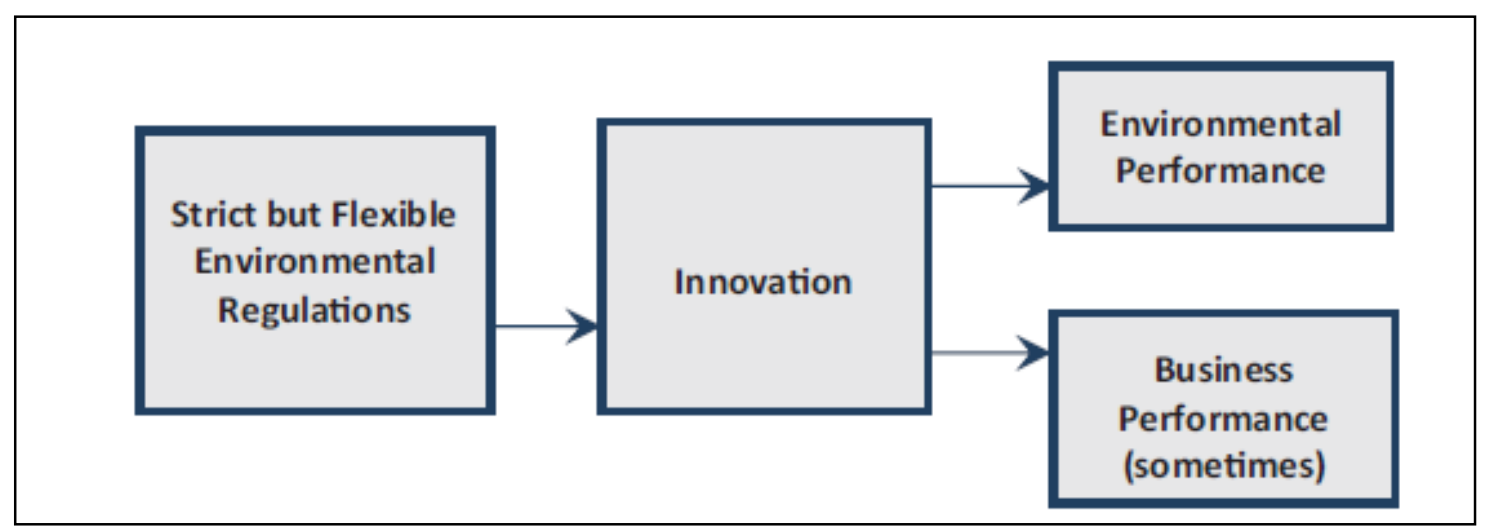

The Porter Hypothesis can take different forms according to the strength of the effect and the type of regulation (Jaffe and Palmer, 1997). The 'weak' version states that regulation will spur innovation. Thus, firms respond by innovating to reduce their costs from the environmental regulation (i.e. the first causal link in Figure 2). Yet, this weak version does not indicate if this innovation is good or bad for a firm's economic performance. The 'strong' version says that the regulation induces firms to find new products or processes that increase profits while complying with the regulation. According to this strong version, the benefits of the regulation more than offset its costs. This would make the regulation socially desirable even when ignoring any environmental improvements arising from it. The 'narrow' version of the Porter Hypothesis states that only certain types of regulation (e.g. flexible instruments) will encourage innovation.

The regulation needs to be sufficiently flexible and focus on the outcome (i.e. the emission reduction) rather than the process (i.e. the technology firms need to adopt) to induce innovation. Market-based regulations (taxation, emission trading schemes) would therefore be preferable to command-and-control regulations (Ambec et al. 2013). The firm-level empirical literature tends to fall into one of two categories: studies testing the weak version (i.e. the link between environmental regulation and innovation activity), and those testing the strong version (i.e. the impact of environmental regulation through innovation on business performance).

10. For example, in the United States, aggregate manufacturing jobs declined by 35 percent between 1998 and 2009, while total manufacturing sector production grew by 21 percent (Kahn and Mansur, 2013). 
The former is often assessed through $R \& D$ expenditures or the number of registered patents. The latter is often assessed through effects on productivity, profits or stock market returns.

The Porter Hypothesis was initially criticized for its lack of theoretical foundation, as it rests on the idea that firms ignore opportunities to improve their business performance. Following Porter and van der Linde (1995) a sizeable literature has emerged to provide the theoretical basis for the hypothesis, by highlighting the existence of additional market failures (beyond the environmental pollution externality). Examples for such market failures include asymmetric information within firms (Ambec and Barla, 2002), learning-by-doing (Mohr, 2002), and market power (Greaker, 2003). For example, in a theoretical model, Mohr (2002) assumes that the existence of knowledge spillovers prevents the replacement of an old polluting technology by a new, cleaner and more productive technology, as firms have a second-mover advantage if they wait for someone else to adopt. In this case, the introduction of an environmental regulation induces firms to switch to the new, cleaner technology, which simultaneously improves environmental quality and eventually increases productivity. This example illustrates that the strong version of the Porter hypothesis is theoretically possible.

The growing importance of the debates over the many consequences of pollution on health, biodiversity loss, climate change, and so on, and the potential negative consequences of environmental regulations on economic performance has led to a large number of studies that attempt to empirically quantify the impact of environmental regulations on the economic and the environmental performance of businesses. Multiple dimensions of economic performance of regulated businesses have been analysed, including productivity, innovation, employment, profitability, output and trade. Similarly, numerous environmental performance indicators have been used, including energy consumption, carbon emissions, emissions of various local pollutants (NOx, SOx, etc.) as well as composite indicators. These are typically used based on absolute values (e.g. emissions in tonnes, energy consumption in $\mathrm{kWh}$ ) or relative values (e.g. energy intensity).

\subsection{The impact of environmental policies on economic outcomes}

The empirical literature on the effects of environmental policies on economic outcomes - such as growth, trade, investment, productivity and employment - is well developed. Most investigations have focused on the impact of environmental policies in the context of corroborating fears of the losses of competitiveness and productivity - broadly related to the so-called Pollution Haven Hypothesis ${ }^{11}$ - and hopes of reaping potentially overlooked productivity gains in the context of the so-called Porter Hypothesis.

The richness of this literature also implies that it has been extensively reviewed. In particular, a series of recent reviews (Dechezleprêtre and Sato, 2017; Cohen and Tubb, 2017; Kozluk and Zipperer, 2015) does a thorough job and our intention is not to attempt to replicate that. Instead, we summarise the findings of these reviews, complemented by most recent papers. Empirical papers tend to look at outcomes such as innovation, productivity, profits, sales, employment, entry and exit, and trade and FDI. Most papers are within-country studies, focusing on the effects of the introduction or increase in the stringency of a specific environmental policy.

A broad interpretation of the results of the empirical literature is that the cost-burden of environmental regulation has been found to be rather small. However, effects of more stringent environmental policies are context-specific and existing analyses focus on short-term and partial equilibrium effects. Effects on

11 The so-called Pollution Haven Hypothesis (PHH) stipulates that by increasing the costs of polluting, environmental policies provide industries with incentives to relocate some stages of production to jurisdictions with laxer environmental regulations or to source inputs from them (for reviews, see Brunnermeier and Levinson, 2004; Copeland and Taylor, 2004; Jaffe et al., 1995). As a result of costs induced by stringent environmental policies, jurisdictions that introduce them are seen as potentially loosing competitiveness against those that maintain laxer regulation. For comprehensive reviews of the empirical literature on such claims see Dechezleprêtre and Sato (2017) and Kozluk and Timiliotis (2016). 
economic outcomes tend to be statistically insignificant in general (though a large amount of studies finds positive effects too), but environmental regulations can also lead to statistically significant adverse effects on economic performance in the short-run, particularly in pollution- and energy-intensive sectors for which the environmental or energy regulatory costs are substantial. However, a general consensus seems to be that these adverse effects tend to be "small" relative to other changes going on in the economy (e.g. changes in transport costs, proximity to demand, potential to cost-pass-through etc.) and often depend on firm or industry characteristics. Moreover, evidence of the "weak" version of Porter's hypothesis - i.e. that environmental policies tend to induce innovation - seems well established (Bellas and Lange, 2011; Calel and Dechezleprêtre, 2017), while there seems little reasons to believe that this innovation leads to overall better economic performance, as would be in the case of the "strong" version of PH (Dechezleprêtre and Sato, 2017; Kozluk and Zipperer, 2014).

The "small" nature of the effects is further confirmed in more recent cross-country panel studies such as Albrizio et al. (2017) for productivity growth. This paper tends to find heterogeneous effects across firms depending on how far away they are from global industry leaders in terms of productivity. Moreover, it finds heterogeneous effects across time - with (small) short-term effects, eventually disappearing.

The recent literature on economic effects of environmental policies tends to be more preoccupied with causality - benefitting from more advanced micro-econometric methods and better data availability. On the one hand, micro studies exploiting thresholds and policy discontinuities are now the most popular approach, allowing the identification of causal effects. The downside is that they are difficult to generalise - as any event studies - and it is difficult to control for other local or concurring policies and developments. Micro studies by nature tend to be partial equilibrium, and would tend to be better placed to capture the direct "costs" - i.e. the negative effects, particularly as they often focus on energy and pollution intensive industries - than to capture the second order benefits, such as those coming from a cleaner environment or healthier workers, which may generally be more difficult to be appropriated by a firm. Finally, a general feature of these studies is a fairly loose approach to the timing of effects - many studies would not attempt to distinguish potentially different short and longer term effects. However, the distinction can be crucial due to the way competitiveness and costs are measured. For example, environmental policies that induce increased investment (in capital and innovation) or increased employment (e.g. R\&D staff) can show up as reduced profits and productivity resulting in losses of competitiveness in the short term. However, such investments can in principle have offsetting beneficial effects over the longer term - hence increasing economic outcomes of firms.

To address the shortcomings of micro studies, a strand of literature looks at effects from a cross-country perspective, allowing better control for national policies and circumstances, better generalisation of results, but being generally less clean on causality. As cross-country natural policy experiments are scarce, such studies tend to use more recently available environmental policy stringency proxies, such as the OECD's Environmental Policy Stringency (Botta and Kozluk, 2014) or international and sectorial variation in energy prices (Sato et al. 2015). As such policy proxies tend to be available at the national level, an identification strategy similar to Rajan and Zingales (1998) is commonly applied, whereby effects on global value chains (Kozluk and Timiliotis, 2016), on investment (Dlugosch and Kozluk, 2017) and on FDI (Garsous and Kozluk, 2017) are analysed.

Going back in time, the first significant review of the literature on the impact of environmental policies on economic outcomes, Jaffe et al. (1995), found little evidence of large resulting losses in competitiveness. It is fair to say, that over two decades later, and notwithstanding the caveats discussed above, this view tends to be confirmed - environmental policies generally do not tend to have large negative effects on economic activity. 
In principle, the main objective of environmental policies is to enhance environmental quality. Yet, the empirical evidence on the environmental performance of environmental policies is surprisingly shallow i.e. de facto, the environmental effectiveness, at the firm level, tends to be more assumed than investigated. The epidemiology literature predominantly researches the link between pollution levels and public health, but puts less attention on the precise origins of the changes in pollution levels. Economists, on the other hand, tend to focus on environmental policies' effects on economic outcomes such as competitiveness. Since - as argued in the previous section - most papers concerned with economic effects such as loss of competitiveness, tend to find small, if any, negative effects of environmental policies, the scarcity of empirical evidence on the policies' environmental effectiveness is even more surprising. Understanding the environmental effectiveness of environmental policies is crucial for answering the basic question: Do we see hardly any negative impact on competitiveness because environmental policies are a red herring - i.e. they do not have much environmental impact either? Or is it that they are more of a free lunch - i.e. they can provide substantial benefits in terms of environmental protection without harming the pure economic performance?

Evaluating the impact of environmental policies on pollution levels in a causal manner is still challenging. One reason is the nature of environmental policies. Many of them have an exhaustive coverage, covering a population of operating entities in the respective state or country. This prevents researchers from observing a credible counterfactual, i.e. how emissions would have evolved in the absence of the policy. For others, where discrete changes in policies - such as different stringency applying to different facilities - are analysed, the selection into treatment is based on endogenous characteristics of the facility, making the disentangling of such effects cumbersome.

Another key reason for the lack of analysis is the scarcity and nature of environmental performance data. Data on emissions is often gathered through ambient monitoring - and hence reported on an aggregated country or regional level or for a given location - without the attribution of the origins of the emissions. Sectoral and facility level data is often not monitored directly, but estimated - based on industry and technology specific parameters - again making monitoring the actual effects problematic. Some registries, such as the European Union Transaction Log or the national Pollution Release and Transfer Registers (PRTRs), provide micro data, but cover only installations that are affected by the respective policy, or above certain thresholds.

Nevertheless, the progress in collection of environmental data such as data from monitoring stations recording air pollution or installation-level data from PRTRs has become increasingly available in the last two decades, allowing researchers to make advances in the understanding of effects of policies. Policies analysed in empirical studies using micro data include the Clean Air Act and the $\mathrm{SO}_{\mathrm{x}}$ Trading Scheme in the United States, the European Union's Emission Trading Scheme and more recently British Columbia's carbon tax in Canada.

\subsubsection{The effectiveness of command and control regulations}

The US Clean Air Act and its Amendments (CAAA) is one of the most extensively studied command and control regulations. It defines federal guidelines to reduce emissions, but leaves much of its implementation and enforcement to the county level. If a county exceeds a federally set emissions ceiling for a certain pollutant, it is in 'non-attainment' status and, hence, faces incentives to introduce regulations for reducing emissions, which counties in attainment do not face. These incentives include more stringent regulations for new manufacturing firms, stricter requirements to reduce source emissions for existing firms, and submissions of plans how to be brought into attainment. The majority of studies on the CAAA make use of monitoring stations and analyses the effect of the policy on ambient emissions $\left(\right.$ Ozone, $\left.\mathrm{SO}_{2}, \mathrm{PM}_{10}\right)$ using 
temporal variation of counties' compliance status to proxy environmental stringency ${ }^{12}$. Overall, they find that being assigned non-attainment status under the CAAA results in a decline of ambient emissions. Yet, recent studies suggest that counties put particular effort in reducing pollution around monitoring stations rather than improving the overall air quality. This finding reveals a key limitation of relying exclusively on monitoring stations for policy analysis and shows a key advantage of source-based micro-data (Auffhammer et al., 2009; 2011; Bento et al., 2015).

Firm- or plant-level micro data allow for a more precise attribution of policies' effects because changes in ambient emission levels might also be caused by other factors, which are not always controlled for (e.g. weather conditions, traffic or changes in population demographics and consumption patterns). Greenstone (2003) uses data from the U.S. Toxic Release Inventory (TRI) to analyse the impact of CAAA's air pollution standards between 1987 and 1997, focussing on the iron and steel sector. Using a differences-in-differences (DiD) approach, this study finds that plants in non-attainment counties reduced their total emissions from lead by $7.1 \%$ relative to installations in attainment counties (PM: 3.5\%; VOC's: 5.6\%). Focussing on the chemical industry, Gamper-Rabindran (2009) finds that VOC emissions decreased by $21 \%$ between 1988 and 2001 using the same methodology as Greenstone (2003). More recently, Gibson (2016) expands Greenstone's approach by including all industries. He finds that treated plants reduced their $\mathrm{PM}_{10}$ emissions by between 33 and $38 \%$ relative to non-treated plants. This reduction is much higher than the 11 to $14 \%$ reduction reported in Auffhammer et al. (2011) for ambient concentrations - potentially because of the limited direct contribution of industrial emissions.

Combining pollution data from the Canadian National Pollution Transfer and Release Inventory with financial data on the firm level from the Annual Manufacturing Survey, Najjar and Cherniwchan (2018) analyse the impact of air pollution regulation in Canada on pollution levels and pollution intensities. Much like the CAAA, the Canada Wide Standards for Particulate Matter and Ozone (CWS) divides the counties into attainment and non-attainment counties, but also explicitly address 'targeted industries' that were subject to stricter regulations. This allows for exploiting variation in the stringency of regulation across regions, industries, and time. Using plant-level data from 2004 to 2010, they find that the CWS is associated with a $15 \%$ reduction in $\mathrm{PM}_{2.5}$ emissions and a 33\% reduction in $\mathrm{NO}_{\mathrm{X}}$ emissions. Overall, Najjar and Cherniwchan (2018) conclude that the CWS explains up to $61 \%$ of the clean-up of the Canadian manufacturing.

\subsubsection{The effectiveness of environmental taxes}

Most papers of the empirical ex-post literature analyse the impact of carbon taxes using sector-level or country-level data on $\mathrm{CO}_{2}$ emissions (for example: Li and Lin, 2011; Elgie and McClay, 2013; Rivers and Schaufele, 2015). Examining the environmental effectiveness of the British Columbian carbon tax, Ahmadi (2017) provides one of the first assessments using plant-level GHG emissions. He uses data from the Annual Survey of Manufacturing (ASM) to estimate the causal effect of the BC carbon tax on emissions using more than 20000 plant-year observations. ${ }^{13}$ Combining the data for plant-level fuel purchases from the ASM with fuel prices and embodied GHG emissions of each fuel type, the author is able to calculate plant-specific GHG emissions. The analysis is complicated by the fact that the economic recession starting in 2009 seems to have affected Canadian provinces in a different way. To address this concern, Ahmadi (2017) exploits the variation in exposure to the carbon tax and assigns only BC installations with high exposure, proxied by high

\footnotetext{
${ }^{12}$ Henderson (1996), Greenstone (2004), Chay and Greenstone (2003, 2005). Researchers have also used the CAAA as an instrument to estimate the impact of pollution on infant mortality (Chay and Greenstone, 2003, Sanders and Stoecker, 2015), housing prices (Chay and Greenstone, 2005; Grainger, 2012), distributional aspects of environmental policy (Bento et al., 20154), worker reallocation (Walker, 2011), and worker productivity (Isen et al., 2017). tax using micro-data. This paper is reviewed in the next section.
} 
emission intensity, as treatment group. To control for unobserved time-varying province-specific heterogeneity, he estimates a triple difference regression that compares the differential change in emissions for plants with high and low emission intensity in $\mathrm{BC}$ before and after implementation of the carbon tax, to the same differential change in the counterfactual plants in other provinces. While the standard DiD approach points to a significant reduction of $\mathrm{CO}_{2}$ emissions in the order of $8 \%$, the triple difference method yields a $2 \%$ reduction which is not statistically significant from zero. Yet, the emission-intensity of plants declined significantly by $7 \%$. The lack of a decline in carbon emissions could be due to the revenue-neutral design of the policy. In parallel with the carbon tax, corporate tax rates were lowered to reduce negative impacts on competitiveness. The author concludes that firms appear to have increased their output as a response to the decline in the corporate tax rates, which prevented a decline in emissions, but in combination with the carbon tax resulted in a decline in emissions intensity.

Most studies using firm-level data do not explicitly evaluate the impact of carbon or energy taxes, but focus on the relationship between energy prices and energy demand, assuming that more stringent environmental regulation will translate directly or indirectly into higher energy prices. These papers usually set up factor demand models to estimate the own-price elasticity and the cross-price elasticities for energy, labour, and capital. Pioneering works on panel data and cross-section estimations have been performed by Woodland (1993) on Australian firms, Nguyen and Streitwieser (1999) on US firms, and Bjorner and Jensen (2002) on Danish firms, all of which report own-price elasticities of energy to be negative in the range between -0.4 to below -3.8. More recent studies report similar results for Denmark (-0.45, Arnberg and Bjorner, 2007), Ireland (-1.5, Haller and Hyland, 2014), and Italy (-1.13, Bardazzi et al., 2015).

Few papers look at non energy-related environmental taxes with micro data. Millock and Nauges (2006) analyse the effect of the French tax on air pollutants $\left(\mathrm{SO}_{2}, \mathrm{NO}_{\mathrm{x}}, \mathrm{HCI}\right.$, and VOC) based on a sample of 226 plants from the chemical, coke and iron and steel sector. Estimating a fixed effects model without control group, they find that the elasticity of emissions with respect to the tax to be between -0.21 and -2.67 depending on the pollutant and economic sector. The Swedish nitrogen oxide tax with refund payments has been studied most extensively. Although this literature does not provide a direct estimate of the effectiveness regarding emission reduction, it provides evidence that plants have invested in advanced abatement technologies (Isaksson, 2005), using a variety of different technologies (Sterner and Turnheim, 2009), thereby reducing the emission intensity. Ancev et al. (2012) evaluate the load based licencing (LBL) scheme for $\mathrm{NO}_{\mathrm{X}}$ emissions in New South Wales on $\mathrm{NO}_{\mathrm{X}}$ emissions based on a sample of 85 industrial plants between 2000 and 2009. They exploit the variation of the pollutant fee, which originates from area-specific emission rates varying over time, to identify the impact of the $\mathrm{LBL}$ on $\mathrm{NO}_{\mathrm{x}}$ emissions. Their results suggest that the LBL had a negative, but statistically not significant effect on reducing emissions, potentially due to the relatively low levels of the fee (the Swedish tax on $\mathrm{NO}_{\mathrm{x}}$ emissions is 100 times higher). This result is confirmed by Contreras et al. (2014) who do not find a significant impact of the LBL on emission intensities of $\mathrm{NO}_{\mathrm{x}}, \mathrm{PM}$, and Fine Particulate Matter for electricity generating units.

\subsubsection{The effectiveness of emissions trading schemes}

Emissions trading schemes have become more and more popular in the last years, in particular for mitigating climate change. The basic idea is that a central authority sets the maximum level of pollution, i.e. the cap, while polluters are required to hold permits equal to the amount of their emissions. Polluters can trade the permits among each other, thereby guaranteeing to achieve the given environmental target at the least cost.

By far the biggest market for tradable emission permits is the European Union Emissions Trading System (EU ETS), implemented in 2005 and covering the GHG emissions of more than 12000 power plants and industrial facilities in 31 countries. A comprehensive review on ex-post evaluations of the EU ETS on emission reductions is provided by Martin et al. (2016). As for any comprehensive environmental regulation, 
assessing the effectiveness of the EU ETS requires to know the counterfactual emissions. Counterfactual emissions have been estimated based on aggregate emissions, and based on firm or plant-level data.

McGuiness and Ellerman (2008) use power plant-data from the United Kingdom in order to estimate the effect of the EU ETS on abatement for the first phase. Based on a fuel switching model, they estimate that natural gas utilization increased by about 22 percent while coal utilization decreased by 17 percent, resulting in annual emission reductions between 13 and $21 \mathrm{Mt} \mathrm{CO}_{2}$. Six other studies to date have used installationlevel data to provide causal estimates of the effect of the EU ETS on regulated installations' carbon emissions. As these studies also shed light on the economic performance of ETS-installations, they are reviewed in the next section.

Another local carbon market, established in 2009, is the Regional Greenhouse Gas Initiative (RGGI) that covers the emissions of fossil-fuelled power plants in 10 north-eastern U.S. states. Fell and Maniloff (2018) estimate the impact of the RGGI program on reducing emissions using daily and yearly generator-level data from 2004 to 2012. They use a DiD design to estimate the causal effect of the programme on power generation capacity, focusing in particular on coal plants. Their findings suggest that the RGGI program led coal fired power plants to reduce their capacity utilization by 10 percentage points and that the generation was not compensated by gas-fired generation in the same regulated region. Thus, they examine possible leakage to non-regulated regions and observe that power generation capacity increased in neighbouring unregulated regions. However, the leakage increased the capacity of relatively cleaner plants so that overall emissions still declined as a result of the policy.

The $\mathrm{SO}_{2}$ trading program (Acid Rain Program) in the US was the first large experiment with a cap-and-trade mechanism. In Phase I (1995 - 1999), the 263 most SO$_{2}$-emission intensive units were covered, while Phase II covered virtually all generating units (Stavins, 2005). The bulk of the literature assumes that the $\mathrm{SO}_{2}$ trading was effective in reducing emissions (Schmalensee et al. 1998). Most reduction estimates rely on EPA's projections of the counterfactual, but this projection is complicated by major uncertainties with respect to the remaining lifetime of existing facilities, the rates of adoption of clean production processes and the growth in electricity demand (Chestnut and Mills, 2005). EPA (2015) reports that units covered by the Acid Rain Program reduced annual $\mathrm{SO}_{2}$ emissions in 2015 by 13.5 million tons or 87 percent relative to 1990.

The design, the performance, and the challenges of other emissions trading schemes are reviewed in Schmalensee and Stavins (2017). Two papers use a quasi-experimental study design to estimate the impact of trading schemes on emissions reductions in a causal manner. Deschenes et al. (2017) analyse the $\mathrm{NO}_{\mathrm{X}}$ Budget Trading Program (NBTP) that operated between 2003 and 2008 covering around 2,500 electricity generating units in eastern and mid-western states in the US. Since the NBTP aimed at reducing ozone pollution, which typically reaches its highest levels in summer, the market operated only between 1 May to 30 September. Hence, Deschenes et al. (2017) make use of a triple difference technique comparing the emission levels between participating and non-participating states, before versus after, and summer versus winter. Using unit-level data, they find that the NBP led to a statistically significant reduction between 391 000 and 521000 tons $\mathrm{NO}_{\mathrm{X}}$ in each summer, which translates into a decrease of the mean summer ozone by about 6 percent. Fowlie et al. (2012) examine the Southern California REgional CLean Air Incentive Market (RECLAIM) that started in 1994 and included 392 industrial $\mathrm{NO}_{\mathrm{X}}$ and $\mathrm{SO}_{2}$ emitters. They exploit the fact that RECLAIM covers only facilities in Southern California, whereas all other Californian installations continue to be regulated under command-and-control. Using installation-level data and applying a matched DiD study design they estimate that RECLAIM facilities have reduced their $\mathrm{NO}_{\mathrm{X}}$ emissions by $20 \%$ relative to non-regulated installations in the first 10 years of RECLAIM. 


\subsubsection{Summing-up}

In the last ten years, this literature strand has seen much progress by using more advanced estimation techniques such as matched DiD study designs and by making use of new micro datasets that allow for establishing a causal relationship between environmental policies and its impact on environmental quality. This trend is likely to continue in the future as more and more environmental data from various sources becomes available. However, some challenges in the evaluation of environmental policies will remain. The comprehensive coverage of environmental policies exacerbates the policies' assessment in a causal manner. Hence, making use of randomised controlled trials, that are increasingly used in other policy areas such as labour market policies and welfare programmes (Gueron and Rolston, 2013), would certainly facilitate the evaluation of the effectiveness of environmental policies.

Across the board - regardless of the environmental policy instrument analysed - most of the reviewed papers find a significant reduction of emissions as a result of the policy.

As shown above, both command and control policies and emission pricing are effective environmental instruments. At the same time, it is often argued that pricing instruments provide incentives to reduce emissions in a cost-effective way since economic agents internalise the emissions price in their abatement decisions. Although this insight dates back to Pigou (1920), environmental taxes only have become popular in the last three decades and emission trading schemes are even more recent (OECD, 2017). To what extent they actually deliver on the expectation is an empirical question that can only be addressed when looking at the environmental and economic effects jointly.

\subsection{The joint impact of environmental regulations on environmental and economic performance}

Most studies have so far assessed the impact of environmental regulations on environmental and economic performance separately (for reviews, see Ambec et al., 2013; Arlinghaus, 2015; Cohen and Tubb, 2017; Dechezleprêtre and Sato, 2017; Endrikat et al., 2014; Friede et al. 2015; Iraldo et al., 2011; Jaffe et al., 1995; Kozluk and Zipperer, 2015; Lankoski, 2010; Martin et al., 2016). However, a critical input for policy makers implementing environmental regulations is an understanding of how such policies will impact both environmental quality and local businesses' economic performance. As a consequence, some recent studies have started to jointly analyse these dimensions.

A large literature has analysed the impacts of environmental regulations on environmental performance, while another strand of the literature - somewhat less rich - has looked at the consequences on economic performance. Ideally, we would like to know whether environmental policies were effective in environmental terms and whether or not they were accompanied by detrimental economic effects. Observing only one of the two dimensions does not allow for a comprehensive evaluation of the respective policy. Yet, despite some progress in the last years the empirical literature regarding the joint economic effects and the environmental outcome is still very scattered. This makes it hard to draw conclusions about the joint environmental and economic impact of specific environmental policies because the respective results originate from studies using different datasets, focussing on distinct countries and/or economic sectors. Notably, the key papers have focused on climate change regulations, and within this literature, most papers analyse the effect of the European Union Emissions Trading System (EU ETS).

\subsubsection{The joint impact of the EU ETS on carbon emissions and firm performance}

In 2005, the EU ETS - the EU's flagship climate change policy - was launched in 24 countries across Europe. The policy regulates the carbon emissions of around 12,000 installations, together representing roughly $40 \%$ of the EU's total greenhouse gas emissions, by allocating pollution permits to these installations, which can then be freely traded on an international permit market. The objective of this cap-and-trade programme is to 
achieve a set reduction of aggregate $\mathrm{CO}_{2}$ emissions at minimal cost. Power stations and industrial plants across Europe were classified according to their main activity: combustion, cement, paper and pulp, and so on. The EU ETS offers a unique opportunity to investigate the causal impact of environmental policy on both environmental and economic performance. It is the first and largest environmental policy initiative of its kind anywhere in the world, which, by itself, would make it an interesting case to study.

But more important is the fact that, in order to control administrative costs, the EU ETS was designed to cover only large installations. Activity-specific size criteria determine which installations would be included in the EU ETS. For instance, only combustion installations with a yearly thermal input exceeding $20 \mathrm{MWh}$ are covered. Firms operating smaller installations are not covered by EU ETS regulations. It is therefore possible to exploit these installation-level inclusion criteria to compare firms or installations with similar environmental and economic performance prior to the introduction of the EU ETS, but which have fallen under different regulatory regimes since 2005 . This provides an opportunity to apply the sort of quasiexperimental techniques most suited to assessing the causal impacts of environmental policies (List et al., 2003; Greenstone and Gayer, 2009).

The central outcome of interest for a policy such as the EU ETS are $\mathrm{CO}_{2}$ emissions. The only source for representative emissions data for both EU ETS and non-EU ETS plants are confidential business surveys maintained by government statistical agencies. Access to these datasets is restricted and subject to disclosure control. This explains why few studies so far have been set out to understand the impact of the EU ETS on the economic and environmental performance of regulated installations, through the use of comprehensive plant-level data. To date, four studies have explored the joint effect of the EU ETS on firms' and installations' environmental and economic performance, respectively in France, Germany, Norway and Lithuania.

\section{France}

Using comprehensive plant-level data for around 9500 French manufacturing firms, Wagner et al. (2014) explore the economic and environmental response of plants to the introduction of the EU ETS. The analysis is based on a combination of energy consumption and economic performance data at the facility and firm level. The EACEI (Enquete Annuelle sur les Consommations d'Energie dans l'Industrie) is a survey conducted annually in France. It provides quantities and values of energy consumed by energy type (electricity, vapour, natural gas, coal, lignite, coke, butane, propane, fuel oil, heating oil, wood, etc.). About 12000 establishments are part of the sample: all industrial establishments employing 20 employees or more in the most energy consuming sectors, all establishments with more than 250 employees, and a sample of establishments with employment between 20 and 249 employees in sectors that are not energy intensive. Fuel consumption information at the plant level is then converted into carbon emissions based on widely available carbon content data on the various fuels consumed. This dataset is combined with EAE (Enquête Annuelle des Entreprises), which collects balance-sheet data at the firm level on turnover, employment, capital, and aggregate wages, as well as information about firm location and industry classification. The data are available for all firms with more than 20 employees and all the plants of those firms. Finally, the data is matched on the European Union Transaction Log, which contains the list of all installations regulated under the EU ETS. Notably, in France, the national registry is managed by the Caisse des Dépôts and their website provides a link between the EUTL permit identifier (GIDIC) and the French unique firm identifier SIREN, allowing a quasi-perfect matching of the two databases.

To examine the causal effect of the EU ETS on environmental and economic performance, Wagner et al. (2014) combine matching with difference-in-differences. For each EU ETS-regulated plant, they use propensity score matching to identify the most similar non-EU ETS plant (nearest neighbour), which becomes part of the control group and helps determining what would have been the behaviour of regulated plants, had they not been regulated. Ideally, one would want to directly use the production capacity of the plants to create such pairs, since it is production capacity pre-EU ETS that determines inclusion into the 
system. However, this variable is not observed by the researchers. Therefore, they use carbon intensity of each plant in the year 1999, the announcement year of the EU ETS, as the main matching variable. They also match each plant exactly on sector at the NACE two-digit level. This means that each EU ETS plant is compared with a non-EU ETS plant operating in the same two-digit sector and having the same carbon intensity before the announcement of the EU ETS. A potential problem is the absence of size variables in the matching process, which might induce the authors to compare plants of different sizes and thus different on unobserved characteristics as well.

Their results suggest that ETS-regulated manufacturing plants in France reduced emissions by an average of $15 \%$. The analysis shows no effect of the EU ETS during Phase I (2005-2007) and a 15\% reduction in emissions during Phase II compared to unregulated plants. Having facility level data, Wagner et al. (2014) can explore if there is any evidence of within firm leakage for firms with both unregulated and regulated facilities. One would expect that it would be easier for such firms to shift emissions to unregulated plants as they are incurring less transaction costs than firms who have no pre-existing links with unregulated facilities. However, they do not find any evidence for such within-firm carbon emissions reallocation effects. Instead, the reduction in emissions appears to be driven mostly by reductions in the carbon-intensity of production. In particular, about half of the reduction in emissions can be accounted for by an increase in the share of gas, which is less carbon intensive than coal and oil. In terms of economic outcomes, Wagner et al. (2014) do not find any statistically significant impact on employment, suggesting that the EU ETS was effective at reducing carbon emissions of regulated plants with no statistically significant effect on domestic jobs in France.

\section{Germany}

Petrick and Wagner (2014) analyse the causal impact of the EU ETS on German manufacturing firms using comprehensive panel data from the German production census. Contrary to Wagner et al. (2014) who use data on French plants, their analysis is conducted at the firm level. They are able to match 1,658 EU ETS facilities to the German AFiD company database, a database comprising official firm-level data from the German Federal Statistical Office. They use propensity score matching to select a group of comparable but unregulated firms, and base this on a comparably much richer set of observable pre-treatment characteristics: $\mathrm{CO}_{2}$ emissions, gross output, export share of output, number of employees, average wage, the squares of all these variables, and dummies for two-digit industry (WZ classification) and state (Bundesland) wherein the firm is located.

Petrick and Wagner (2014) find robust evidence that phase II of the EU ETS caused treated firms to reduce their emissions by a substantial margin, in the order of 25 to 28 percentage points more than non-treated firms. In parallel, carbon intensity fell between 18 and 30 percentage points faster at EU ETS firms than at the control firms. This suggests that firms responded to the introduction of the EU ETS mainly by adjusting intensity, not scale. Furthermore, firms were found to have reduced their carbon emissions by switching from high-carbon fuels (natural gas and oil) to low-carbon fuels (electricity).

Turning to economic outcomes, Petrick and Wagner (2014) find no statistically significant effects of the EU ETS on employment. In a word, putting a price on carbon does not seem to come at the expense of domestic job destruction. As for gross output, they estimate that the EU ETS increased gross output at regulated firms by a statistically significant amount of between 4 and 7 percent. While this allows the authors to reject the hypothesis that the EU ETS caused firms to reduce the scale of production, the positive effect on gross output is surprising and consistent with both firms producing more or charging higher prices. Unfortunately, they cannot distinguish between these two responses for lack of a measure of physical output. Similarly, they reject the hypothesis that the EU ETS caused regulated firms to reduce their overall exports, but they even find that the EU ETS increased total exports by $6 \%$ to $11 \%$ for phase I and by $7 \%$ to $18 \%$ for phase II. Again, it is not clear whether the increase in exports reflects an increase in the volume of shipments or a price increase, or both. 
In a panel study of Norwegian plants, Klemetsen et al. (2016) analyse the effect of the EU ETS on emission levels and intensity (defined as emissions divided by man hours). They find weak evidence that regulated plants reduced emissions by a large amount $(-30 \%)$ in the EU ETS' second phase, and no evidence that emission intensity decreased in any of the phases. This suggests that, to the extent that the ETS participation led to emissions reductions in phase II, this occurred through reduced activity level rather than through reduced emissions intensity.

The authors use plant level data from the Norwegian Environment Agency for the period 2001 to 2013 on annual emissions of all Norwegian plants regulated by the Norwegian ETS or the Norwegian Pollution Control Act, including emissions of $\mathrm{CO}_{2}, \mathrm{~N}_{2} \mathrm{O}$ and PFCs (measured in $\mathrm{CO}_{2}$ equivalents). It allows them to identify which plants were regulated by the EU ETS. Their sample includes 665 plants of which 150 plants are regulated by the EU ETS. They consider two measures of economic performance: value added at factor prices, which is the plant's annual gross production value minus the cost of intermediates plus subsidies and minus taxes (except VAT), and labour productivity, defined as value added at factor prices per man hour. For Phase II, the estimated effects on both value added and productivity are positive and significant, and suggest increases of around 25\%. These surprising effects could result from the impact that free allowances or cost pass-through may have had on value added.

Propensity score matching techniques are used to construct a control group of similar but unregulated plants. Exact matching is done on type of pollutant $\left(\mathrm{CO}_{2}, \mathrm{~N}_{2} \mathrm{O}\right.$ or PFCs) and on industry classification at two-digit level. Continuous matching variables include emissions levels of emissions (as a proxy for capacity limit) and number of employees (as a measure of plant size) in the pre-treatment year 2001. Not all EU ETS regulated plants can be matched, hence the final matched sample includes 152 plants of which 72 plants are regulated by the EU ETS. However, it is notable that the control group still appears quite different from the treatment group even after matching with, for example, an average $\mathrm{CO}_{2}$ intensity of $62.1 \%$ in the treatment group and only $6.8 \%$ in the control group. Therefore, it is questionable how comparable the treated and control groups are in this study.

\section{Lithuania}

Finally, Jaraite and Di Maria (2016) analyse the impact of the EU ETS on $\mathrm{CO}_{2}$ emissions and economic performance in Lithuania for the period 2005-2010 using plant-level data. They compare 41 EU ETS firms with 312 non-EU ETS firms matched through propensity score-matching. They find no reductions in emissions and a slight improvement in emissions intensity in 2006-2007, but their data does not allow them to study effects on emissions beyond 2007. When it comes to economic performance, Jaraite and Di Maria (2016) find no significant impacts of the EU ETS on Lithuanian firms' profitability.

\section{Pan-European studies}

At present, only two papers have analysed the joint effect of the EU ETS on $\mathrm{CO}_{2}$ emissions and economic performance based on data from more than one country of the European Union. Abrell et al. (2011) use data on 2101 firms across Europe representing around 60\% of EU ETS regulated emissions to assess reductions in $\mathrm{CO}_{2}$ emissions induced by the transition from Phase I to Phase II of the programme, which occurred in 2008. They find that emission reductions were 3.6\% higher between 2007 and 2008 than between 2005 and 2006, a difference which they attribute to the increased stringency of the regulation. This finding is robust to controlling for turnover, employment, profits, and industry and country trends, suggesting that the reduction in emissions is due to the change in stringency from Phase I to Phase II (i.e. the lower allocation of permits) and not to a decrease in production. Abrell et al. (2011) then apply a nearest-neighbour matching procedure to their sample of EU ETS firms and find that the policy caused a small but significant decrease 
in employment of 0.9 percent between 2004 and 2008. One limitation of the matching procedure is that, as Martin et al. (2014a) explain, taking control firms only from non-regulated sectors is problematic, because of the possible non-random selection of which sectors were regulated under the EU ETS, hence the study is likely to suffer from selection bias at the sector level.

More recently, Dechezleprêtre et al. (2018) combine two sources of data. First, they take carbon emissions data at the installation level from the national Pollutant Release and Transfer Registers (PRTR) from France, Netherlands, Norway and the United Kingdom, complemented with data from the European PRTR. Second, financial data and other firm-level performance data such as employment, fixed assets, profits, and revenues come from the global financial database Orbis, which includes all 31 countries covered by the EU ETS. Using the European Union Transactions Log (EUTL), they can identify installations and firms covered and not covered by the EU ETS.

They employ a matching procedure in which each treated installation and firm is matched to the closest installation and firm operating in the same economic sector and country and similar in all other observable characteristics before the introduction of the EU ETS. This control group combined with a difference-indifferences estimation allows to estimate the policy's causal impact on installations' emissions and on firms' revenue, assets, profits and employment. Dechezleprêtre et al. (2018) find that the EU ETS has led to carbon emission reductions of around $-10 \%$ between 2005 and 2012 while not having any adverse impact on firms' economic performance. The EU ETS has not had any negative effect on regulated firms' revenue, profits, fixed assets or jobs. In fact, the EU ETS rather seems to have led to an increase of revenues and fixed assets of regulated firms - contrary to what could have been expected. Dechezleprêtre et al. (2018) argue that one explanation for these results is that the EU ETS induced regulated firms to increase investment - likely in carbon-saving technologies - which, in turn, may have increased productivity.

\subsubsection{The joint impact of the UK Climate Change Levy on carbon emissions and firm performance}

The UK Climate Change Levy (CCL) is a carbon tax associated with a scheme of voluntary agreements (called Climate Change Agreements) available to plants in selected energy intensive industries. Upon joining a CCA, a plant adopts a specific target for energy consumption or carbon emissions in exchange for an $80 \%$ discount on the tax liability under the CCL. Martin et al. (2014a) analyse the impact of the CCL on energy use, emissions and economic performance of regulated plants for the period 2001-2004 based on micro-level data.

The identification strategy of the paper is to compare changes in outcomes between fully-taxed CCL plants and CCA plants which pay the reduced tax rate. Since plants self-select themselves into a CCA, it is not possible to implement a straightforward DiD strategy. However, a key feature of eligibility for CCAs is that plants needed to emit pollutants subject to environmental regulation under the Pollution Prevention and Control (PPC) act which pre-dated the CCL. This variation in eligibility across plants can hence be used as an instrument for CCA participation. Indeed, since eligibility is based on pollution intensity, many energy intensive industries are ineligible for the tax discount. For instance, textile wet processing was an eligible activity thanks to its high pollution emissions, but not so dry processing which, although energy intensive, emits no pollution regulated under PPC. Similarly, both the production and the recycling of glass containers are very energy-intensive processes. However, since only the former is pollution-intensive, glass container recycling was not eligible for CCA participation. This institutional feature induces exogenous variation in the probability of treatment even within narrowly defined, energy-intensive industrial sectors.

The core dataset is the Annual Respondents Database (ARD), an annual production survey that covers about 10000 plants in the manufacturing sector. Energy use comes from the Quarterly Fuels Inquiry (QFI), a survey among a panel of about 1000 manufacturing plants which can be matched to the ARD. Information on CCA participation comes from both the Department for Environment, Food and Rural Affairs (DEFRA) 
and HM Revenue and Customs (HMRC) websites. Finally, data for the instrumental variable comes from the European Pollution Emissions Register (EPER). The final dataset includes 6,886 plants, among which 1,079 have detailed information on fuel consumption by type.

Instrumental variable estimations show that the CCL had a strong negative impact on energy intensity $(-18 \%)$, particularly at larger and more energy intensive plants. This seems mainly driven by a reduction in electricity use, which translates into a negative impact on $\mathrm{CO}_{2}$ emissions. The results suggest that firms substituted labour for energy and increased output prices in response to the energy price increase. In contrast, the authors do not find any statistically significant impacts of the tax on employment, revenue (gross output) or TFP. Similarly, no evidence is found that the CCL accelerated plant exit.

\subsubsection{The joint impact of energy prices on economic and environmental performance}

To examine more generally the effect of energy prices on firms' environmental and economic performance, Marin and Vona (2017) use three rich datasets provided by the French Statistical Office covering the period 1997 to 2010: the EACAI survey for establishment-level energy purchases and consumption, DADS (Déclaration Annuelle des Données Sociales) for data on employment and wages, and FARES-FICUS for information on firms' balance sheets. By combining these datasets they can use differences across establishments in energy intensities, -prices, and -mixes. Hereby, energy intensities provide a proxy for establishments' exposure to energy price changes, and the energy mix (i.e. the use of electricity versus natural gas and other fuels) indicates establishments' technology and the relative exposure to price changes for the respective energy source. Energy use and $\mathrm{CO}_{2}$ emissions capture firms' environmental impact, and employment, wages and productivity are used as economic outcomes.

To estimate the effect of electricity prices on firms' environmental and economic outcome variables Marin and Vona (2017) use both a simple fixed effects model, as well as an Instrumental Variable (IV) specification. The latter is important to address concerns of endogeneity due to non-observed variables, which could bias the results of the simple fixed effects model. Such variables could be firm-specific demand shocks or technological change as a response to changes in energy prices. These variables are likely to be correlated with both the outcome variables and energy prices, resulting in a biased estimation of the model. To overcome this concern the authors require an instrumental variable that is correlated with the exogenous variation in energy prices but not related to establishment-specific technological responses to changes in energy prices. They use a combination of the nationwide price of energy with a fixed firm-specific energy mix, which does not change over time (shift-share instrument). Changes in nationwide prices are uncorrelated with firm-specific demand shocks dealing with the first concern. Since most endogenous technological change operates through changes in the mix of energy sources, holding fixed the energy mix addresses the second source of potential bias.

In their preferred specification with the Instrumental Variable, Marin and Vona (2017) identify a trade-off between environmental and economic goals: A $10 \%$ increase in establishment-level energy prices, leads to a reduction in energy consumption and $\mathrm{CO}_{2}$ emissions by $6.4 \%$ and $11.5 \%$ respectively. Yet, the same increase in energy prices also leads to a modest negative effect on employment $(-2.6 \%)$, wages $(-0.4 \%)$ and firm's productivity $(-1.1 \%)$. The negative employment impacts differ across sectors with energy-intensive and trade-exposed sectors experiencing the largest decline. However, preliminary evidence shows a substantial reallocation of production inputs between establishments of the same firm as a response to energy price changes. This gives reasons to believe that the estimated employment impacts are upper bounds. Some of the employees that are observed as losing their job at one establishment are simply relocated to another establishment within the same firm. 


\subsubsection{The joint impact of environmental regulation on environmental and economic performance through innovation}

Several studies have examined the causality chain implied by the Porter hypothesis -- from regulation to innovation to profitability -- and find that the positive effect of innovation on business performance does not outweigh the negative effect of the regulation itself (Lanoie et al., 2011). Thus, environmental regulation is costly, but it is less costly than if one were to consider only the direct costs of the regulation itself and ignore the ability of innovation to mitigate those costs. This is because over time, regulation-induced innovations that improve a firm's resource efficiency in terms of material or energy consumption, have a positive impact on profitability (Rexhauser and Rammer, 2014).

This doesn't preclude the possibilities that environmental regulations induce new green technology leaders higher up the supply chain, but to our knowledge no study has looked at effects of such regulation on the entire supply chain. Yet, some evidence suggests that environmental regulation can trigger innovation from technology suppliers (Bellas and Lange, 2010; Bellas et al., 2013). Further research could jointly look at the environmental and economic performance taking into account the whole supply chain.

Porter and van der Linde (1995) also argue that countries that take early action in environmental protection will induce higher costs for domestic firms in the short run, but that the induced innovation will generate economic benefits in the long run by giving domestic firms a competitive advantage over foreign firms, which will be constrained by the same regulation later on. However, to our knowledge, no study has empirically analysed whether this first-mover advantage actually leads to competitiveness improvements in the long-run.

\subsubsection{Summing up}

Because economists traditionally think of environmental regulations as forcing firms away from the optimum by requiring them to implement costly abatement activities that divert resources away from productive investments, it is all the more interesting that this literature - scarce as it is - finds that environmental regulations tend to improve environmental performance while hardly weakening economic performance. The evidence on the EU ETS suggests that in particular Phase II of the policy causally induced reductions in GHG emissions in regulated plants in the range of $15-30 \%$ relative to non-regulated plants. At the same time the regulation has not resulted in loss of employment and might have even increased gross output of regulated plants. These findings might be specific to the EU ETS design and due to the overallocation of emission permits, which have resulted in windfall profits for regulated plants. Whether these results hold in a stricter policy environment without a surplus in permits will need to be tested. At the same time, these findings also show that relatively weak environmental regulation can lead to substantial reductions in emissions without hurting competitiveness. Similarly, the existing studies on energy-price regulations in the UK and France suggest that such pricing policies are effective at reducing firms' energy-intensity and GHG emissions with at worst small negative impacts on employment and competitiveness.

So far, no study confirms the so-called strong version of the Porter hypothesis, which postulates that environmental regulations can improve at the same time environmental and economic performance. Yet, it is important to note that Porter and van der Linde (1995) were referring to particular types of 'well-designed' environmental regulation. These regulations would need to be sufficiently flexible and incorporate a marketbased mechanism with clear and reliable price signals that provide incentives for innovation. Moreover, they would need to cover a comprehensive set of pollutants and economic sectors moving away from "piecemeal solutions" (p.111). Given the existing deficiencies in environmental regulations (e.g. exemptions for particular industries, over-allocation and a low permit price in the EU ETS) it might not be surprising that we do not yet observe effects confirming the strong version of the Porter Hypothesis. 


\section{Conclusions}

There is still a widespread belief among economists of a trade-off between economic performance and environmental outcomes of firms, claiming that good environmental performance would jeopardize business activities by adding costs and diverting resources from more productive use, thereby slowing down productivity and reducing international competitiveness. This article has reviewed two strands of the available empirical literature, combining economic and environmental performance data at the micro-level: First, is the issue of whether economic and environmental performance can go hand in hand, and where the main finding is that the majority of studies report a positive relation between environmental performance and economic outcomes. This finding is probably not very surprising because good environmental performance could be driven by profit-enhancing motivations of firms.

Addressing the potential reverse causality in these findings is an important, albeit challenging avenue for future research. Moreover, expanding the scope to industries beyond manufacturing and energy generation would be valuable to assess the generalizability of current findings. Improved environmental performance indicators at the firm-level would also offer promising avenues for future research. These could for example focus on the 'greenness' of firms' supply chains, production processes, their product mix or investment decisions. Most studies reviewed here focused on GHG emissions and toxic release emissions. Further work is required on different environmental performance variables such as firms' impact on biodiversity.

The second issue reviewed is about the impact of environmental regulations on firms' environmental and economic outcomes. The conclusion of Jaffe et al. (1995), who find little evidence of adverse economic impacts of environmental regulation, has become even more robust in the last ten years through numerous studies using different datasets from different countries and sectors while applying more advanced econometric techniques. This is an important finding for policy-makers, which needs to be communicated more effectively. It remains crucial that environmental policies allow sufficient flexibility for firms to adjust. Environmental taxes or market based mechanisms fulfil these requirements and have the potential for Portertype effects. Redistributive mechanisms and revenue-neutrality of pricing policies can play an important role in increasing the political acceptance and in cushioning socio-economic impacts for particularly affected groups. The political acceptance and the political economy of environmental policies play an increasingly important role and should be considered when designing and implementing new policies.

The vast majority of studies on the impact of environmental regulation focus on economic impacts, while abstracting from the effectiveness in environmental terms. In fact, environmental effectiveness is often assumed, but not investigated in more detail. Given the evidence from studies finding only small, if any, adverse impact of environmental policies on economic outcomes, the question of whether environmental policies are improving environmental performance is even more pressing. In the last ten years, this strand of literature has seen much progress, particularly as more and more environmental data has become available. The recent evidence suggests that both command and control policies and economic instruments lead to a statistically significant improvement of the environmental performance. While economic theory suggests that pricing an environmental bad reduces emissions in a cost-effective way, the empirical literature on the cost-effectiveness of different environmental policy instruments still lacks evidence and is one avenue for future research.

Another avenue for future research is to continue the evaluation of the economic and environmental performance of environmental policies by making use of new (micro) datasets in different contexts and countries to update and reassess the existing evidence. Most of the evidence originates from studies that analyse the impact of environmental policies on economic and environmental outcome separately. Ideally, we would like to know the impact of the same environmental instrument in the same regulatory context on both firms' environmental performance and their business activities. Only the joint analysis of both outcomes is appropriate for this kind of evidence and, thus, should be followed further. 
The joint analysis of economic and environmental performance is still in its infancy and has obvious limitations. Most studies have used a single policy experiment, the EU ETS, and focus on a single country. They rely on relatively small samples, and tend to cover a very narrow subset - of albeit important environmental policy instruments. This has some key implications, limiting the ability to distinguish e.g. short versus longer term effects or finding counterfactual references. Only one multi-country study is currently available, while cross-country studies would enable researchers to determine which combination of public policies (instruments for environmental policy, innovation policy, fiscal policy, etc.) works best at inducing the greatest benefits in terms of improved environmental performance, while implying the smallest costs or, potentially, the greatest improvements in terms of economic performance (productivity, etc.).

Still, while the generalisation is difficult, the relative freshness of this literature means that it tends to at least attempt to look for causal effects, which is hardly the case in the earlier studies of effects of environmental policies. Because the implementation of environmental regulations can sometimes be claimed to be exogenous (this is in particular the case for the EU ETS, which uses arbitrary administrative thresholds to determine inclusion), this allows for more confidence in the identification of causal links.

Establishing causal relationships between environmental regulations and firms' outcomes will remain the gold standard in the empirical literature. However, the comprehensive coverage of most environmental policies exacerbates the compliance with this standard. This calls for policy designs that allow for a more robust evaluation of the effectiveness of regulations, including the phase-in of new regulations in different regions at different points in time or the use of randomized controlled trials. In fact, randomized controlled trials are already successfully used in other policy areas such as labour market policies and welfare programmes. Making use of these policy designs in combination with new data sources such as pollution data of point sources gathered from satellites would significantly improve the available evidence on the impact of environmental policies on both environmental and economic outcomes. 


\section{REFERENCES}

Abrell, J., A. Ndoye Faye, and G. Zachmann (2011), "Assessing the impact of the EU ETS using firm level data”, Bruegel Working Paper, No. 2011/08.

Ahmadi, Y. (2017), How Effective Are Carbon Taxes in Reducing Emissions? Evidence from the Revenue Neutral Carbon Tax in British Columbia, Canada, Working Paper. Available at: https://younesahmadi.files.wordpress.com/2016/10/bc-carbon-tax-effects2.pdf.

Albertini, E. (2013), "Does environmental management improve financial performance? A metaanalytical review", Organization and Environment, 26 (4): 431-457.

Albrizio, S., T. Koźluk and V. Zipperer (2017), "Environmental policies and productivity growth: Evidence across industries and firms", Journal of Environmental Economics and Management, 81: 209-226.

Al-Tuwaijri, S., T. E. Christensen and K.E Hughes II (2004), "The relations among environmental disclosure, environmental performance, and economic performance: a simultaneous equations approach", Accounting, Organizations and Society, 29 (5-6): 447-471.

Ambec, S. and P. Barla (2002), "A theoretical foundation of the Porter hypothesis", Economics Letters, 75 (3): 355-360.

Ambec, S. and P. Lanoie (2007), "When and why does it pay to be green?", Discussion Paper, No. IEA-0704.

Ambec, S. and P. Lanoie (2008), "Does it pay to be green? A systematic overview", Academy of Management Perspectives, 22 (4): 45-62.

Ambec, S., M.A. Cohen, S. Elgie, and P. Lanoie (2013), "The Porter hypothesis at 20: can environmental regulation enhance innovation and competitiveness?", Review of Environmental Economics and Policy, 7 (1): 2-22.

Ancev, T., R. Betz and Z. Contreras (2012), "The New South Wales load based licensing scheme for NOx: Lessons learnt after a decade of operation", Ecological Economics, 80: 70-78.

Antweiler, W., and K. Harrison (2003), “Toxic Release Inventories and Green Consumerism: Empirical Evidence from Canada", Canadian Journal of Economics, 36 (2): 495-520.

Arlinghaus, J. (2015), "Impacts of Carbon Prices on Indicators of Competitiveness: A Review of Empirical Findings", OECD Environment Working Papers, No. 87, OECD Publishing, Paris.

Arnberg, S. and T. Bjørner (2007), "Substitution between energy, capital and labour within industrial companies: A micro panel data analysis", Resource and Energy Economics, 29 (2): 122-136.

Attig, N., S.E. Ghoul, O. Guedhami, J. Suh (2013), "Corporate Social Responsibility and Credit Ratings", Journal of Business Ethics, 117 (4): 679-694.

Auffhammer, M., A. Bento and S. Lowe (2009), "Measuring the effects of the Clean Air Act Amendments on ambient PM 10 concentrations: The critical importance of a spatially disaggregated analysis", Journal of Environmental Economics \& Management, 58: 15-26. 
Auffhammer, M., A. Bento and S. Lowe (2011), "The City-Level Effects of the 1990 Clean Air Act Amendments", Land Economics, 87 (1): 1-18.

Ayerbe, C.G. and C.G. Gorriz (2001), "The effects of environmental regulations on the productivity of large companies: an empirical analysis of the Spanish case", Journal of Management and Governance, 5: $129-152$.

Bardazzi, R., F. Oropallo and M. Pazienza (2015), "Do manufacturing firms react to energy prices? Evidence from Italy", Energy Economics, 49: 168-181.

Bellas, A.S., and I. Lange (2010), Technological Progress in particulate removal equipment at U.S. coal burning power plants, Journal of Regulatory Economics, 38 (2), 180-192.

Bellas, A.S. and I. Lange (2011), "Evidence of Innovation and Diffusion Under Tradable Permit Programs", International Review of Environmental and Resource Economics", 5, 1-22.

Bellas, A.S., D. Finney, and I. Lange (2013), Technological Advance in Cooling Systems at U.S. Power Plants, Economics of Energy \& Environmental Policy, 2(2), 137-148.

Bento, A., M. Freedman and C. Lang (2015), "Who benefits from environmental regulation? Evidence from the Clean Air Act Amendments", The Review of Economics and Statistics, 97 (3): 610-622.

Bjørner, T. and H. Jensen (2002), "Energy taxes, voluntary agreements and investment subsidies-a micropanel analysis of the effect on Danish industrial companies' energy demand", Resource and Energy Economics, 24 (3): 229-249.

Blanco, E., J. Rey-Maquieira and J. Lozano (2009), "The Economic Impacts of Voluntary Environmental Performance of Firms: A Critical Review”, Journal of Economic Surveys, 23 (3): 462-502.

Bloom, N., C. Genakos, R. Martin, and R. Sadun (2010), "Modern management: Good for the environment or just hot air?", Economic Journal, 120 (544): 551-572.

Botta, E. and T. Koźluk (2014), "Measuring Environmental Policy Stringency in OECD Countries: A Composite Index Approach", OECD Economics Department Working Papers, No. 1177, OECD Publishing, Paris.

Broberg, T., P. Marklund, E. Samakovlis, and H. Hammar, (2013), "Testing the Porter Hypothesis: the effects of environmental investments on efficiency in Swedish industry", Journal of Productivity Analysis, 40 (1): 43-56.

Brunnermeier, S. and A. Levinson (2004), "Examining the evidence on environmental regulations and industry location", The Journal of Environment \& Development, 13 (1): 6-41.

Calel, R. and A. Dechezleprêtre (2016), "Environmental Policy and Directed Technological Change: Evidence from the European Carbon Market", Review of Economics and Statistics, 98 (1): 173-191.

Chay, K. and M. Greenstone (2003), "Air Quality, Infant Mortality, and the Clean Air Act of 1970", NBER Working paper, No. 10053.

Chay, K. and M. Greenstone (2005), "Does Air Quality Matter? Evidence from the Housing Market", Journal of Political Economy, 113 (2): 376-424. 
Cheng, B., I. Ioannou, G. Serafeim (2013), "Corporate Social Responsibility and Access to Finance", Strategic”, Management Journal, 35 (1): 1-23.

Chestnut, L. and D. Mills (2005), "A fresh look at the benefits and costs of the US acid rain program", Journal of Environmental Management, 77 (3): 252-266.

Cohen, M.A., and A. Tubb, (2017), "The Impact of Environmental Regulation on Firm and Country Competitiveness: A Meta-Analysis of the Porter Hypothesis", Vanderbilt Graduate School of Management Research Paper, No 2692919.

Contreras, Z., T. Ancev and R. Betz (2014), "Evaluation of Environmental Taxation on Multiple Air Pollutants in the Electricity Generation Sector-Evidence from New South Wales, Australia", Economics of Energy \& Environmental Policy, 3: 119-144.

Copeland, B. and M. Taylor (2004), "Trade, Growth, and the Environment", Journal of Economic Literature, 42 (1): 7-71.

Crifo, P. and B. Sinclair-Desgagné (2013), "The Economics of Corporate Environmental Responsibility", International Review of Environmental and Resource Economics, 7, 279-297.

Crifo, P. and V. D. Forget (2015), "The Economics of Corporate Social Responsibility: A Firm-Level Perspective Survey", Journal of Economic Surveys

Darnall, N. (2009), "Regulatory Stringency, green production offsets, and organizations' financial performance", Public Administration Review, 69: 418-434.

Dechezleprêtre, A. and M. Sato (2017), "The Impacts of Environmental Regulations on Competitiveness", Review of Environmental Economics and Policy, 11 (2): 183-206.

Dechezleprêtre, A., D. Nachtigall and F. Venmans (2018), "The joint impact of the European Union emissions trading system on carbon emissions and economic performance", OECD Economics Department Working Papers, No. 1515, OECD Publishing, Paris. http://dx.doi.org/10.1787/4819b016-en

Delmas, M. A. and S. Pekovic (2013), "Environmental standards and labour productivity: Understanding the mechanisms that sustain sustainability", Journal of Organizational Behavior, 34: 230-252.

Deschênes, O., M. Greenstone and J. Shapiro (2017), "Defensive Investments and the Demand for Air Quality: Evidence from the NOx Budget Program", American Economic Review, 107 (10): 29582989.

Dlugosch, D. and T. Koźluk (2017), "Energy prices, environmental policies and investment: Evidence from listed firms", OECD Economics Department Working Papers, No. 1378, OECD Publishing, Paris.

El Ghoul, S., O. Guedhami, C.C.Y. Kwok and D.R.Mishra (2011), "Does corporate social responsibility affect the cost of capital?", Journal of Banking \& Finance, 35 (9): 2388-2406.

Elgie, S. and J. McClay (2013), "BC's Carbon Tax Shift Is Working Well after Four Years (Attention Ottawa)", Canadian Public Policy, 39 (S2): S1-S10. 
Endrikat, J., E. Guenther, and H. Hoppe (2014), "Making sense of conflicting empirical findings: A metaanalytic review of the relationship between corporate environmental and financial performance", European Management Journal, 32: 735-751.

EPA (2015), “2015 Program Progress - Cross-State Air Pollution Rule and Acid Rain Program”, Report. Available at: https://www3.epa.gov/airmarkets/progress/reports/index.html.

Fell, H. and P. Maniloff (2018), "Leakage in regional environmental policy: The case of the regional greenhouse gas initiative", Journal of Environmental Economics and Management, 87: 1-23.

Fowlie, M., S. Holland and E. Mansur (2012), "What Do Emissions Markets Deliver and to Whom? Evidence from Southern California's NOX Trading Program", American Economic Review, 102 (2): 965-993.

Friede, G., T. Busch and A. Bassen (2015), "ESG and financial performance: aggregated evidence from more than 2000 empirical studies", Journal of Sustainable Finance \& Investment, 5 (4): 210-233.

Fujii, H., K. Iwata, S. Kaneko, and S. Managi (2013), "Corporate Environmental and Economic Performance of Japanese Manufacturing Firms: Empirical Study for Sustainable Development". Business Strategy and the Environment, 22: 187-201.

Gamper-Rabindran, S. (2009), The Clean Air Act and volatile organic compounds: Did plants reduce their health-indexed air emissions or shift their emissions into other media?, Working paper. Available at: https://www.maxwell.syr.edu/uploadedfiles/cpr/events/cpr_seminar_series/previous_seminars/rabin dran.pdf.

Garsous, G. and T. Koźluk (2017), "Foreign Direct Investment and The Pollution Haven Hypothesis: Evidence from Listed Firms", OECD Economics Department Working Papers, No. 1379, OECD Publishing, Paris.

Gibson, M. (2016), Regulation-induced pollution substitution, Working paper. Available at: https://web.williams.edu/Economics/wp/GibsonPollutionSubstitution.pdf.

Gosnell, G., J. List and R. Metcalfe (2017), "A new approach to an age-old problem: solving externalities by incenting workers directly", Grantham Research Institute on Climate Change and the Environment Working Paper, No. 262.

Goss, A. and G.S. Roberts (2011), "The Impact of Corporate Social Responsibility on the Cost of Bank Loans", Journal of Banking \& Finance, 35 (7): 1794-1810.

Grainger, C. (2012), "The distributional effects of pollution regulations: Do renters fully pay for cleaner air?", Journal of Public Economics, 96 (9-10): 840-852.

Gray, W.B. and R.J. Shadbegian (2003), "Plant vintage, technology, and environmental regulation", Journal of Environmental Economics and Management, 46 (3): 384-402.

Greaker, M. (2003), "Strategic environmental policy; eco-dumping or a green strategy?", Journal of Environmental Economics and Management, 45 (3): 692-707.

Greenstone, M. and T. Gayer (2009), "Quasi-Experimental and Experimental Approaches to Environmental Economics," Journal of Environmental Economics and Management, 57 (1): 21-44. 
Greenstone, M. (2004), "Did the Clean Air Act cause the remarkable decline in sulfur dioxide concentrations?", Journal of Environmental Economics and Management, 47: 585-611.

Grolleau, G., N. Mzoughi and S. Pekovic (2012), "Green not (only) for profit: An empirical examination of the effect of environmental-related standards on employees' recruitment", Resource and Energy Economics, 34: 74-92.

Gueron, J.M. and H. Rolston (2013), Fighting for reliable evidence, New York: Russell Sage.

Haller, S. and M. Hyland (2014), "Capital-energy substitution: Evidence from a panel of Irish manufacturing firms", Energy Economics, 45: 501-510.

Henderson, J. (1996), “Effects of Air Quality Regulation”, The American Economic Review, 86 (4): 789813.

Hibiki, A., M. Higashi and A. Matsuda (2003), "Determinants of the Firm to Acquire ISO14001 Certificate and Market Valuation of the Certified Firm", Discussion Paper, $\mathrm{N}^{\circ}$ 03-06, Department of Social Engineering, Tokyo Institute of Technology, Tokyo.

Horbach, J. (2010), "The Impact of Innovations Activities on Employment in the Environmental Sector Empirical Results for Germany at the Firm Level”, Journal of Economics and Statistics, 230 (4): 403419.

Horbach, J. and K. Rennings (2013), "Environmental Innovation and Employment Dynamics in Different Technology Fields - An Analysis Based on the German Community Innovation Survey 2009”, Journal of Cleaner Production, 57: 158-165.

Horváthová, E. (2010), "Does Environmental Performance Affect Financial Performance? A MetaAnalysis", Ecological Economics, 70 (1): 52-59.

Horváthová, E. (2012), “The impact of environmental performance on firm performance: short-term costs and long-term benefits?", Ecological Economics, 84: 91-97.

Iraldo, F., F. Testa, M. Melis, and M. Frey, (2011), "A Literature Review on the Links between Environmental Regulation and Competitiveness", Environmental Policy and Governance, 21: 210222.

Isaksson, L. (2005), "Abatement costs in response to the Swedish charge on nitrogen oxide emissions", Journal of Environmental Economics and Management, 50 (1): 102-120.

Isen, A., M. Rossin-Slater and W. Walker (2017), "Every Breath You Take-Every Dollar You'll Make: The Long-Term Consequences of the Clean Air Act of 1970", Journal of Political Economy, 125 (3): 848-902.

Jacobs, B.W., R. S. Vinod and R. Subramanian (2010), "An empirical investigation of environmental performance and the market value of the firm", Journal of Operations Management, 28 (5): 430-441.

Jaffe, A. B., S.R. Peterson, P.R. Portney, and R.N. Stavins (1995), "Environmental Regulation and the Competitiveness of U.S. Manufacturing: What Does the Evidence Tell Us?", Journal of Economic Literature, 33 (1): 132-163. 
Jaffe, A.B., and K. Palmer (1997), "Environmental Regulation and Innovation: A Panel Data Study", The Review of Economics and Statistics, 79 (4): 610-619.

Jaraite, J. and C. Di Maria (2016), "Did the EU ETS Make a Difference? An Empirical Assessment Using Lithuanian Firm-Level Data”, The Energy Journal, 37 (1): 1-23.

Kahn, M. E., \& Mansur, E. T. (2013), "Do local energy prices and regulation affect the geographic concentration of employment?", Journal of Public Economics, 101: 105-114.

Khanna, D. and L.A. Damon (1999), "EPA's Voluntary 33/50 Program: Impact on Toxic Releases and Economic Performance of Firms", Journal of Environmental Economics and Management, 37 (1): 125.

King, A.A. and M.J. Lenox (2001), "Does it really pay to be green? An empirical study of firm environmental and financial performance", Journal of Industrial Ecology, 5 (1): 105-116.

Klemetsen, M. E., K. E. Rosendahl and A. L. Jakobsen (2016), "The impacts of the EU ETS on Norwegian plants' environmental and economic performance", NMBU Working Papers, No. 3/2016.

Konar, S. and M. A. Cohen (2001), "Does the market value environmental performance?", Review of economics and statistics, 83 (2): 281-289.

Koźluk, T. and C. Timiliotis (2016), "Do environmental policies affect global value chains?: A new perspective on the pollution haven hypothesis", OECD Economics Department Working Papers, No. 1282, OECD Publishing, Paris.

Koźluk, T. and V. Zipperer (2015), "Environmental policies and productivity growth: a critical review of empirical findings", OECD Journal: Economic Studies, 2014 (1): 155-185.

Kumar, S. and S. Managi, (2010), "Sulfur dioxide allowances: Trading and technological progress", Ecological Economics, 69: 623-631.

Lanfranchi, L. and S. Pekovic (2012), "How Green is My Firm? Workers' Attitudes towards Job, Job Involvement and Effort in Environmentally-Related Firms", Center for Employment Studies Working Paper, No. 160.

Lankoski, L., (2010), "Linkages between Environmental Policy and Competitiveness", OECD Environment Working Papers, No. 13. OECD Publishing, Paris.

Lanoie, P., J. Laurent-Lucchetti, N. Johnstone, and S. Ambec (2011), "Environmental policy, Innovation and Performance: New Insights on the Porter Hypothesis", Journal of Economics \& Management Strategy, 20 (3): 803-842.

Levinson, A. and M. Taylor (2008), "Unmasking the pollution haven effect", International Economic Review, 49 (1): 223-254.

Li, B. and X. Lin (2011), "The effect of carbon tax on per capita CO2 emissions", Energy Policy, 39 (9): 5137-5146.

List, J. A. D.L. Millimet, P.G. Frederiksson, W.W. McHone (2003), "Effects of Environmental Regulations on Manufacturing Plant Births: Evidence from a Propensity Score Matching Estimator", Review of Economics and Statistics, 85: 944-952. 
Marin, G. and F. Vona (2017), "The Impact of Energy Prices on Employment and Environmental Performance: Evidence from French Manufacturing Establishments", SEEDS Working Paper Series, No. 07/2017.

Martin, R., M. Muûls and L. de Preux (2012), "Anatomy of a Paradox: Management Practices, Organizational Structure and Energy Efficiency", Journal of Environmental Economics and Management, 63 (2): 208-223.

Martin, R., L. B. de Preux and U. J. Wagner (2014a), "The impact of a carbon tax on manufacturing: Evidence from microdata", Journal of Public Economics, 117: 1-14.

Martin, R., M. Muûls and U. J. Wagner (2016), "The Impact of the European Union Emissions Trading Scheme on Regulated Firms: What Is the Evidence after Ten Years?", Review of Environmental Economics and Policy, 10 (1): 129-148.

McGuinness, M., and A. D. Ellerman (2008), "CO2 abatement in the UK power sector: Evidence from the EU ETS trial period" Center for Energy and Environmental Policy Research Working Paper, No. 0810 .

Millock, K. and C. Nauges (2006), "Ex Post Evaluation of an Earmarked Tax on Air Pollution”, Land Economics, 82 (1): 68-84.

Mohr, R. D. (2002), "Technical Change, External Economies, and the Porter Hypothesis", Journal of Environmental Economics and Management, 43 (1): 158168.

Morgenstern, R., D., W.A. Pizer, and J.S. Shih (2002), "Jobs versus the environment: An industry-level perspective", Journal of Environmental Economics and Management, 43 (3): 412-436.

Najjar, N. and J. Cherniwchan (2018), "Environmental Regulations and the Clean-Up of Manufacturing: Plant-Level Evidence from Canada", University of Alberta Research Paper, No. 2018-701.

Nguyen, S. and M. Streitwieser (1999), "Factor Substitution in U.S. Manufacturing: Does Plant Size Matter?", Small Business Economics, 12 (1): 41-57.

Nyborg, K. and T. Zhang (2013), "Is corporate social responsibility associated with lower wages?", Environmental and Resource Economics, 55 (1): 107-117.

OECD (2009), The Economics of Climate Change Mitigation: Policies and Options for Global Actions beyond 2012, OECD Publishing, Paris.

OECD (2017), Policy Instruments for the Environment, OECD Publishing, Paris.

Palmer, M. and Y. Truong (2017), “The Impact of Technological Green New Product Introductions on Firm Profitability”, Ecological Economics, 136: 86-93.

Petrick, S. and U. J. Wagner (2014), "The impact of carbon trading on industry: Evidence from German manufacturing (RMS)", Kiel Working Paper, No. 1912.

Pfeiffer, F. and K. Rennings (2001), "Employment Impacts of Cleaner Production - Evidence from a German Study Using Case Studies and Surveys", Business Strategy and the Environment, 10 (3): 161-175.

Pigou, A. (1920), The Economics of Welfare, Macmillan and Co., London. 
Porter, M. E. and C. van der Linde (1995), "Toward a New Conception of the Environment- Competitiveness Relationship”, Journal of Economic Perspectives, 9 (4), 97-118.

Porter, M. (1991), “America’s Green Strategy”, Scientific American, 264 (4): 168.

Rajan, R. and L. Zingales (1998), "Financial Dependence and Growth", The American Economic Review, 88 (3): 559-586.

Rassier, D.G., and D. Earnhart (2010a), "The Effect of Clean Water Regulation on Profitability: Testing the Porter Hypothesis”, Land Economics, 86: 329-344.

Rassier, D.G., and D. Earnhart (2010b), "Does the Porter Hypothesis Explain Expected Future Financial Performance? The effect of clean water regulation on chemical manufacturing firms", Environmental and Resource Economics, 45 (3): 353-377.

Rassier, D.G., and D. Earnhart (2011), "Short-run and long-run implications of environmental regulation on financial performance", Contemporary Economic Policy, 29 (3): 357-373.

Rassier, D.G., and D. Earnhart (2015), "Effects of Environmental Regulation on Actual and Expected Profitability", Ecological Economics, 112: 129-140.

Rennings, K. and T. Zwick (2002), "The Employment Impact of Cleaner Production on the Firm Level Empirical Evidence from a Survey in Five European Countries", International Journal of Innovation Management, 6 (3): 319-342.

Rennings, K., A. Ziegler and T. Zwick (2004), “The Effect of Environmental Innovations on Employment Changes: An Econometric Analysis”, Business Strategy and the Environment, 13: 374-387.

Rexhäuser, S. and C. Rammer (2014), "Environmental Innovations and Firm Profitability: Unmasking the Porter Hypothesis", Environmental and Resource Economics, 57 (1): 145-167.

Rivers, N. and B. Schaufele (2015), "Salience of carbon taxes in the gasoline market", Journal of Environmental Economics and Management, 74: 23-36.

Rose, A. (1983), "Modeling the Macroeconomic Impact of Air Pollution Abatement", Journal of Regulatory Science, 23 (4): 441-459.

Sanchez-Vargas, A., R. Mansilla-Sanchez and A. Aguilar-Ibarra, (2013), "An Empirical Analysis of the nonlinear relationship between environmental regulation and manufacturing productivity", Journal of Applied Economics, 16 (2): 357-372.

Sanders, N. and C. Stoecker (2015), "Where have all the young men gone? Using sex ratios to measure fetal death rates", Journal of Health Economics, 41: 30-45.

Sato, M., G. Singer, D. Dussaux and S. Lovo (2015), "International and sectoral variation in energy prices 1995-2011: how does it relate to emissions policy stringency?", Gratham Research Institute Working Papers, No. 187.

Schmalensee, R. (1993), "The Costs of Environmental Protection", in Balancing Economic Growth and Environmental Goods, pp. 53-80, Washington, DC: American Council for Capital Formation. 
Schmalensee, R., P. Joskow, D. Ellerman, J.P. Montero and E. Bailey (1998), "An Interim Evaluation of Sulfur Dioxide Emissions Trading”, Journal of Economic Perspectives, 12 (3): 53-68.

Schmalensee, R. and R. Stavins (2017), "The design of environmental markets: What have we learned from experience with cap and trade?", Oxford Review Of Economic Policy, 33 (4): 572-588.

Shadbegian, R. and W. Gray (2005), "Pollution abatement expenditures and plant-level productivity: A production function approach", Ecological Economics, 54: 196-208.

Shadbegian, R. and W. Gray (2006), "Assessing multi-dimensional performance: environmental and economic outcomes", Journal of Productivity Analysis, 26 (3): 213-234.

Shadbegian, R. and W. Gray (2003), "What determines environmental performance at paper mills? The roles of abatement spending, regulation, and efficiency", The B.E. Economic Analysis \& Policy 3(1).

Stavins, R. (2005), “Lessons Learned from SO2 Allowance Trading”, Choices, 20: 53-57.

Sterner, T. and B. Turnheim (2009), "Innovation and diffusion of environmental technology: Industrial NOx abatement in Sweden under refunded emission payments", Ecological Economics, 68 (12): 29963006.

Telle, K. (2006), It pays to be green - A premature conclusion?, Environmental and Resource Economics, $35,195-220$.

Trumpp, C. and T. Guenther (2017), "Too little or too much? Exploring U-shaped relationships between Corporate Environmental Performance and Corporate Financial Performance", Business Strategy and the Environment, 26: 49-68.

Van Leeuwen, G. and P. Mohnen (2017), "Revisiting the Porter Hypothesis: An empirical analysis of Green Innovation for the Netherlands", Economics of Innovation and New Technology, 26(1-2): 63-77.

Wagner, M. (2001), A Review of Empirical Studies Concerning the Relationship Between Environmental and Economic Performance. What does the Evidence Tell us? Working paper. Available at: http://www.sussex.ac.uk/Units/spru/mepi/outputs/Wagner.PDF.

Wagner, M. and J. Blom (2011), "The reciprocal and non-linear relationship of sustainability and financial performance", Business Ethics: A European Review, 20 (4).

Wagner, U. J., M. Muuls, R. Martin, and J. Colmer (2014), The causal effects of the European Union Emissions Trading Scheme: Evidence from French manufacturing plants. Working Paper. Available at: http://conference.iza.org/conference_files/EnvEmpl2014/martin_r7617.pdf.

Walker, W. (2011), "Environmental Regulation and Labor Reallocation: Evidence from the Clean Air Act", American Economic Review, 101 (3): 442-447.

Walley, N. and B. Whitehead (1994), "It's not easy being green", Harvard Business Review, 72 (3): 46-52.

Woodland, A. (1993), "A Micro-Econometric Analysis of the Industrial Demand for Energy in NSW", The Energy Journal, 14 (2): 57-89. 
APPENDIX 1: SUMMARY TABLE OF EMPIRICAL LITERATURE ${ }^{14}$

\begin{tabular}{|c|c|c|c|c|c|c|}
\hline $\begin{array}{l}\text { Authors, } \\
\text { Year }\end{array}$ & $\begin{array}{c}\text { Environmental } \\
\text { Performance Variable }\end{array}$ & $\begin{array}{c}\text { Economic } \\
\text { Performance } \\
\text { Variable }\end{array}$ & $\begin{array}{l}\text { Sample Size and Data } \\
\text { Source }^{15}\end{array}$ & $\begin{array}{l}\text { Data Structure } \\
\text { (panel/ cross } \\
\text { section) }\end{array}$ & $\begin{array}{l}\text { Interpretation } \\
\text { (correlation/ } \\
\text { causation) }\end{array}$ & Results \\
\hline \multicolumn{7}{|c|}{ Papers reviewed in section 2.1: } \\
\hline $\begin{array}{l}\text { Al-Tuwaijri } \\
\text { et al., } 2014\end{array}$ & $\begin{array}{l}\text { Ratio of toxic waste } \\
\text { recycled to total toxic } \\
\text { waste generated. }\end{array}$ & $\begin{array}{l}\text { Industry-adjusted } \\
\text { annual return } \\
\text { (expressing the } \\
\text { firm's current- } \\
\text { period economic } \\
\text { performance } \\
\text { relative to other } \\
\text { firms in the same } \\
\text { industry). }\end{array}$ & $\begin{array}{l}198 \text { US firms. } \\
\text { IRRC Environmental } \\
\text { Profiles database provided } \\
\text { by the US EPA (accessed } \\
\text { through Freedom of } \\
\text { Information Act requests), } \\
\text { Compustat for financial } \\
\text { data, LexisNexis for } \\
\text { annual reports } \\
\text { (commercial). }\end{array}$ & $\begin{array}{l}\text { Cross-section } \\
\text { (year 1994). }\end{array}$ & Correlation & $\begin{array}{l}\text { Better environmental } \\
\text { performance is } \\
\text { significantly associated } \\
\text { with better economic } \\
\text { performance (significant } \\
\text { only at the } 10 \% \text { level). }\end{array}$ \\
\hline
\end{tabular}

${ }^{14}$ Note that the inclusion criteria for papers covered in the following table are that they use both environmental and economic performance variables at the microlevel.

${ }^{15}$ The respective data sources are characterized according to their access requirements. After each data source we state the access requirements for the respective dataset, where this information was available. We divided access requirements into public, licence, and commercial. Public refers to datasets which are publicly available. Licence typically refers to micro-level datasets provided by public institutions, for which researchers require special access rights. Commercial typically refers to datasets provided by private-sector firms. 


\begin{tabular}{|c|c|c|c|c|c|c|}
\hline & & & $\begin{array}{l}\text { from the Department of } \\
\text { Industry and Energy } \\
\text { (MINER) (public). } \\
\text { Balance Sheet and Income } \\
\text { Statement information are } \\
\text { obtained from the National } \\
\text { Securities Market } \\
\text { Commission (CNMV), } \\
\text { which is available for } \\
\text { publicly listed companies } \\
\text { (licence). }\end{array}$ & & & $\begin{array}{l}\text { small negative association } \\
\text { between work productivity } \\
\text { and pollution abatement } \\
\text { investment dedicated to } \\
\text { compliance with the } \\
\text { pollution standard. They } \\
\text { argue that this result is } \\
\text { specific to the command- } \\
\text { and-control regulation } \\
\text { studied and may not be } \\
\text { generalized to more } \\
\text { flexible types of } \\
\text { regulation. }\end{array}$ \\
\hline $\begin{array}{l}\text { Broberg et } \\
\text { al. } 2013\end{array}$ & $\begin{array}{l}\text { Environmental } \\
\text { protection investment. }\end{array}$ & $\begin{array}{l}\text { Technical } \\
\text { efficiency. }\end{array}$ & $\begin{array}{l}\text { Five Swedish industries: } \\
\text { wood and wood products } \\
\text { ( } 279 \text { obs.), pulp and paper } \\
\text { ( } 304 \text { obs.), chemicals ( } 289 \\
\text { obs.), rubber and plastics } \\
\text { ( } 223 \text { obs.), basic metals } \\
\text { (199 obs.). } \\
\text { Two data sources from } \\
\text { Statistics Sweden: } 1) \\
\text { Industrial Economic } \\
\text { Statistics (licence), } 2) \\
\text { Industries' environmental } \\
\text { protection expenditure } \\
\text { (licence). }\end{array}$ & $\begin{array}{l}\text { Panel (1999- } \\
\text { 2004). }\end{array}$ & Correlation & $\begin{array}{l}\text { They use unique data on } \\
\text { environmental protection } \\
\text { investments in the } \\
\text { Swedish manufacturing } \\
\text { industry as a proxy for } \\
\text { environmental stringency. } \\
\text { This allows them to } \\
\text { separate investments into } \\
\text { pollution prevention and } \\
\text { pollution control. They } \\
\text { use a stochastic production } \\
\text { frontier model to estimate } \\
\text { if environmental } \\
\text { regulation affects firms' } \\
\text { production efficiency. } \\
\text { They do not find support } \\
\text { for the Porter Hypothesis } \\
\text { as they observe a weak } \\
\text { negative relationship } \\
\text { between environmental } \\
\text { investments and technical } \\
\text { efficiency. }\end{array}$ \\
\hline $\begin{array}{l}\text { Darnall, } \\
2009\end{array}$ & $\begin{array}{l}\text { Natural Resource Use, } \\
\text { Solid Waste, Waste- } \\
\text { water effluent, Air } \\
\text { pollution, Greenhouse }\end{array}$ & $\begin{array}{l}\text { Self-reported } \\
\text { profits. }\end{array}$ & $\begin{array}{l}\text { The number of } \\
\text { observations varies across } \\
\text { models due to different } \\
\text { response rates for each }\end{array}$ & $\begin{array}{l}\text { Cross-section } \\
\text { (survey was } \\
\text { conducted in } \\
\text { 2003). }\end{array}$ & Correlation & $\begin{array}{l}\text { The authors use an OECD } \\
\text { survey across seven } \\
\text { countries to test the effect } \\
\text { of regulatory stringency }\end{array}$ \\
\hline
\end{tabular}




\begin{tabular}{|c|c|c|c|c|c|c|}
\hline & $\begin{array}{l}\text { Gases, Overall } \\
\text { environmental impact. }\end{array}$ & & $\begin{array}{l}\text { environmental } \\
\text { performance variable: } \\
\text { Natural resource use } \\
\text { (2609), Solid Waste } \\
\text { (2642), Waste Water } \\
\text { (2386), Air pollution } \\
\text { (2123), GHGs (1723), } \\
\text { Overall environmental } \\
\text { impact (1517). } \\
\text { Survey conducted by the } \\
\text { OECD's Environment } \\
\text { Directorate. }\end{array}$ & & & $\begin{array}{l}\text { on firms' profits. They } \\
\text { find that more stringent } \\
\text { environmental policy } \\
\text { regimes are negatively } \\
\text { correlated with facilities' } \\
\text { profits. This result holds } \\
\text { for each of the individual } \\
\text { environmental } \\
\text { performance variables. }\end{array}$ \\
\hline $\begin{array}{l}\text { Fujii et al., } \\
2013\end{array}$ & $\begin{array}{l}\mathrm{CO}_{2} \text { emissions, } \\
\text { chemical emissions } \\
\text { relative to sales. }\end{array}$ & $\begin{array}{l}\text { Return on Assets } \\
\text { (ROA), Return on } \\
\text { Sales (ROS), } \\
\text { Capital Turnover } \\
\text { (CT). }\end{array}$ & $\begin{array}{l}758 \text { Japanese } \\
\text { manufacturing firms for } \\
\mathrm{CO}_{2} \text { emissions; } 2498 \\
\text { Japanese manufacturing } \\
\text { firms for toxic chemicals } \\
\text { emissions. } \\
\text { GHG emissions from the } \\
\text { mandatory GHG } \\
\text { Accounting and Reporting } \\
\text { System of the Japanese } \\
\text { Ministry of Environment, } \\
\text { Pollutant Release and } \\
\text { Transfer Register (PRTR) } \\
\text { from Ministry of } \\
\text { Environment (licence), } \\
\text { financial data from Nikkei } \\
\text { Economic Electronic } \\
\text { database system (licence). }\end{array}$ & $\begin{array}{l}\text { Panel; for } \mathrm{CO}_{2} \\
\text { emissions (2006- } \\
\text { 2008); for toxic } \\
\text { chemicals } \\
(2001-2008) .\end{array}$ & Correlation & $\begin{array}{l}\text { The relationship between } \\
\text { environmental } \\
\text { performance and financial } \\
\text { performance differs across } \\
\text { pollutants: } \\
\text { For toxic chemical } \\
\text { substances they find a } \\
\text { significant inverted U- } \\
\text { shape relationship } \\
\text { between ROA and } \\
\text { environmental } \\
\text { performance. For } \mathrm{CO}_{2} \\
\text { Emissions they find a } \\
\text { significant positive } \\
\text { relationship between } \\
\text { ROA, ROS and } \\
\text { environmental } \\
\text { performance. They find no } \\
\text { significant relationship } \\
\text { with CT. }\end{array}$ \\
\hline $\begin{array}{l}\text { Gray and } \\
\text { Shadbegian, } \\
2003\end{array}$ & Abatement costs. & Productivity. & $\begin{array}{l}116 \text { US pulp and paper } \\
\text { plants. } \\
\text { Longitudinal Research } \\
\text { Database (LRD) } \\
\text { containing data from the }\end{array}$ & $\begin{array}{l}\text { Panel (1979- } \\
\text { 1990). }\end{array}$ & Correlation & $\begin{array}{l}\text { They test whether the } \\
\text { impact of environmental } \\
\text { regulation on productivity } \\
\text { differs by plant vintage } \\
\text { and technology. Plants } \\
\text { with higher pollution }\end{array}$ \\
\hline
\end{tabular}




\begin{tabular}{|c|c|c|c|c|c|c|}
\hline & & & $\begin{array}{l}\text { Annual Survey of } \\
\text { Manufacturers and the } \\
\text { Census of Manufacturers } \\
\text { linked together, PACE } \\
\text { survey for annual } \\
\text { abatement cost data } \\
\text { (licence). }\end{array}$ & & & $\begin{array}{l}\text { abatement costs have } \\
\text { significantly lower } \\
\text { productivity levels. The } \\
\text { effect depends strongly on } \\
\text { plants' technology. The } \\
\text { negative relationship } \\
\text { between higher abatement } \\
\text { costs and lower } \\
\text { productivity levels is } \\
\text { largely driven by mills, } \\
\text { which incorporate a } \\
\text { pulping process. They } \\
\text { show a strong negative } \\
\text { impact of abatement cost } \\
\text { on productivity. For mills } \\
\text { without such technology } \\
\text { the impact is negligible. }\end{array}$ \\
\hline $\begin{array}{l}\text { Hibiki et al., } \\
2003\end{array}$ & ISO14001 certification. & $\begin{array}{l}\text { Stock returns; } \\
\text { Tobin's Q (market } \\
\text { value of the firm). }\end{array}$ & $\begin{array}{l}573 \text { publicly-held firms in } \\
\text { the manufacturing industry } \\
\text { listed at the Tokyo Stock } \\
\text { Exchange. }\end{array}$ & $\begin{array}{l}\text { Cross-section } \\
\text { (year 2002). }\end{array}$ & Correlation & $\begin{array}{l}\text { The authors find that the } \\
\text { voluntary introduction of } \\
\text { the ISO } 14001 \\
\text { certification contributes to } \\
\text { a statistically significant } \\
\text { increase in the market } \\
\text { value of the firm by } 11 \% \\
\text { to } 14 \% \text {. The authors } \\
\text { explain this finding with } \\
\text { two possible effects: the } \\
\text { expected reduction in the } \\
\text { potential risk of } \\
\text { environmental liabilities, } \\
\text { and the lower adjustment } \\
\text { cost if environmental } \\
\text { policy is tightened in the } \\
\text { future. }\end{array}$ \\
\hline $\begin{array}{l}\text { Horvathova, } \\
2010\end{array}$ & $\begin{array}{l}\text { Environmental } \\
\text { performance (meta- } \\
\text { analysis). }\end{array}$ & $\begin{array}{l}\text { Financial } \\
\text { performance } \\
\text { (meta-analysis). }\end{array}$ & $\begin{array}{l}\text { Meta-analysis of } 64 \\
\text { outcomes from } 37 \\
\text { empirical studies. } \\
\text { Literature search was } \\
\text { conducted in 2008/2009. }\end{array}$ & N/A & Correlation & $\begin{array}{l}\text { The results suggest both } \\
\text { that the empirical method } \\
\text { matters for the findings } \\
\text { and that the likelihood of } \\
\text { finding a negative link }\end{array}$ \\
\hline
\end{tabular}




\begin{tabular}{|c|c|c|c|c|c|c|}
\hline & & & & & & $\begin{array}{l}\text { between environmental } \\
\text { and financial performance } \\
\text { significantly increases } \\
\text { when using simple } \\
\text { correlation coefficients } \\
\text { instead of more advanced } \\
\text { econometric analysis. The } \\
\text { results also indicate that } \\
\text { the portfolio studies tend } \\
\text { to report a negative link } \\
\text { between environmental } \\
\text { and financial performance. } \\
\text { This likely reflects the } \\
\text { omitted factors in portfolio } \\
\text { studies. The positive link } \\
\text { is found more frequently } \\
\text { in common law countries } \\
\text { than in civil law countries. } \\
\text { The results also suggest } \\
\text { that appropriate time } \\
\text { coverage is important in } \\
\text { order to establish a } \\
\text { positive link between EP } \\
\text { and FP. This suggests that } \\
\text { it takes time for } \\
\text { environmental regulation } \\
\text { to materialise in financial } \\
\text { performance. }\end{array}$ \\
\hline $\begin{array}{l}\text { Horvathova, } \\
2012\end{array}$ & $\begin{array}{l}\text { Composite indicator on } \\
93 \text { pollutants (air, water, } \\
\text { land, off-site transfers of } \\
\text { waste, pollutants in } \\
\text { waste water from } \\
\text { industrial facilities). }\end{array}$ & $\begin{array}{l}\text { Return on Assets } \\
\text { (ROA), Return on } \\
\text { Equity (ROE). }\end{array}$ & $\begin{array}{l}136 \text { Czech firms. } \\
\text { Environmental } \\
\text { performance data from } \\
\text { integrated register of } \\
\text { pollutant emissions, which } \\
\text { is part of the European } \\
\text { Pollutant Release and } \\
\text { Transfer register (EPRT) } \\
\text { (publicly available), data }\end{array}$ & $\begin{array}{l}\text { Panel (2004- } \\
\text { 2008). }\end{array}$ & Correlation & $\begin{array}{l}\text { Better environmental } \\
\text { performance decreases } \\
\text { financial performance in } \\
\text { the following year, but } \\
\text { increases financial } \\
\text { performance after two } \\
\text { years. }\end{array}$ \\
\hline
\end{tabular}




\begin{tabular}{|c|c|c|c|c|c|c|}
\hline & & & $\begin{array}{l}\text { on environmental } \\
\text { managerial systems are } \\
\text { collected using publicly } \\
\text { available database } \\
\text { (www.iso.cz) and double- } \\
\text { checking the websites of } \\
\text { companies, financial data } \\
\text { are obtained from a } \\
\text { commercial firm database } \\
\text { CreditInfo (commercial). }\end{array}$ & & & \\
\hline $\begin{array}{l}\text { Jacobs et al., } \\
2010\end{array}$ & $\begin{array}{l}\text { Corporate Environment } \\
\text { Initiatives (CEI) } \\
\text { announcements, which } \\
\text { are self-reported } \\
\text { corporate efforts to } \\
\text { avoid, mitigate or offset } \\
\text { the firm's environmental } \\
\text { impact. Environmental } \\
\text { Awards and } \\
\text { Certification (EAC) } \\
\text { announcements, which } \\
\text { are awards granted by } \\
\text { third parties. EAC } \\
\text { announcements include } \\
\text { ISO 14001 and LEED } \\
\text { certification, as well as } \\
\text { federal, state or local } \\
\text { environmental awards. }\end{array}$ & $\begin{array}{l}\text { Abnormal returns } \\
\text { on stock prices. }\end{array}$ & $\begin{array}{l}340 \text { firms across } 63 \text { three- } \\
\text { digit NAICS codes, with a } \\
\text { total of } 780 \\
\text { announcements; } 417 \\
\text { Corporate Environment } \\
\text { Initiatives (CEI), } 363 \\
\text { Environmental Awards } \\
\text { and Certification (EAC). } \\
\text { Dataset created by authors } \\
\text { through monitoring } \\
\text { business announcements in } \\
\text { newspapers. }\end{array}$ & $\begin{array}{l}\text { Panel; event } \\
\text { study over a } \\
\text { 200-day period, } \\
\text { which is specific } \\
\text { for each firm's } \\
\text { announcement. }\end{array}$ & Correlation & $\begin{array}{l}\text { The authors examine the } \\
\text { stock market reaction } \\
\text { associated with } \\
\text { announcements of } \\
\text { environmental } \\
\text { performance. They find no } \\
\text { significant effect for the } \\
\text { aggregated sample of CEI } \\
\text { and EAC announcements. } \\
\text { Yet, they observe } \\
\text { significant effects for sub- } \\
\text { groups of the } \\
\text { announcements. } \\
\text { Announcements of } \\
\text { philanthropic gifts for } \\
\text { environmental causes and } \\
\text { ISO } 14001 \text { are associated } \\
\text { with a significant positive } \\
\text { market reaction. Voluntary } \\
\text { emissions reductions are } \\
\text { associated with significant } \\
\text { negative market reactions. }\end{array}$ \\
\hline $\begin{array}{l}\text { Khanna and } \\
\text { Damon, } \\
1999\end{array}$ & $\begin{array}{l}\text { Toxic releases of } 17 \\
\text { high priority toxic } \\
\text { chemicals regulated } \\
\text { under the voluntary US } \\
\text { EPA 33/50 Programme. }\end{array}$ & $\begin{array}{l}\text { Return on } \\
\text { Investment (ROI), } \\
\text { Excess value per } \\
\text { unit sales (EVS). }\end{array}$ & $\begin{array}{l}123 \text { US chemical firms. } \\
\text { S\&P's Compustat database } \\
\text { (commercial), CD } \\
\text { corporate database } \\
\text { (commercial), Toxic } \\
\text { Release Inventory (public). }\end{array}$ & $\begin{array}{l}\text { Panel (1991- } \\
1993) .\end{array}$ & Correlation & $\begin{array}{l}\text { Participation in the } \\
\text { voluntary US EPA } 33 / 50 \\
\text { programme led to a } \\
\text { significant decline in toxic } \\
\text { releases relative to non- } \\
\text { participants, after } \\
\text { controlling for sample }\end{array}$ \\
\hline
\end{tabular}




\begin{tabular}{|c|c|c|c|c|c|c|}
\hline & & & & & & $\begin{array}{l}\text { selection through firm- } \\
\text { specific factors. } \\
\text { Programme participation } \\
\text { had a significant negative } \\
\text { effect on current returns } \\
\text { on investment (ROI) } \\
\text { relative to non- } \\
\text { participants. Yet, it had a } \\
\text { significant positive effect } \\
\text { on the Excess Value per } \\
\text { unit Sales (EVS). This } \\
\text { indicates that investors } \\
\text { anticipate that in the long } \\
\text { run the current efforts to } \\
\text { reduce pollution improve } \\
\text { the expected profitability } \\
\text { of firms participating in } \\
\text { the programme. }\end{array}$ \\
\hline $\begin{array}{l}\text { King and } \\
\text { Lenox, } 2001\end{array}$ & $\begin{array}{l}\text { Total Emissions: Total } \\
\text { facility emissions of } \\
\text { toxic chemicals; } \\
\text { Relative Emissions: } \\
\text { Emissions relative to } \\
\text { other facilities of similar } \\
\text { sector, and size. } \\
\text { Industry Emissions: } \\
\text { Emissions per employee } \\
\text { for the sectors in which } \\
\text { the firm operates. }\end{array}$ & $\begin{array}{l}\text { Tobin's Q } \\
\text { financial } \\
\text { performance } \\
\text { measure (market } \\
\text { valuation of a firm } \\
\text { relative to the } \\
\text { replacement costs } \\
\text { of tangible assets). }\end{array}$ & $\begin{array}{l}\text { 652 US manufacturing } \\
\text { firms. } \\
\text { Toxic Release inventory } \\
\text { (TRI), facility data from } \\
\text { Dun and Bradstreet } \\
\text { (D\&B), corporate data } \\
\text { from Standard \& Poor's } \\
\text { Compustat database } \\
\text { (commercial). }\end{array}$ & $\begin{array}{l}\text { Panel (1987- } \\
\text { 1996). }\end{array}$ & Correlation & $\begin{array}{l}\text { The authors identify three } \\
\text { key results: 1) Higher total } \\
\text { emissions are associated } \\
\text { with lower financial } \\
\text { performance. 2) Firms } \\
\text { with higher relative } \\
\text { emissions compared to } \\
\text { firms of similar sector and } \\
\text { size have lower financial } \\
\text { performance. 3) No effect } \\
\text { for Industry Emissions: } \\
\text { Operating in a cleaner } \\
\text { industry does not have an } \\
\text { effect per se on financial } \\
\text { performance. }\end{array}$ \\
\hline $\begin{array}{l}\text { Konar and } \\
\text { Cohen, } 2001\end{array}$ & $\begin{array}{l}\text { The aggregate pounds of } \\
\text { toxic chemicals emitted } \\
\text { per dollar revenue; The } \\
\text { number of } \\
\text { environmental lawsuits }\end{array}$ & $\begin{array}{l}\text { Intangible-asset } \\
\text { value (market } \\
\text { value). }\end{array}$ & $\begin{array}{l}321 \text { mostly manufacturing } \\
\text { firms in the S\&P 500; } \\
\text { Financial performance data } \\
\text { taken from Compustat } \\
\text { (commercial), market }\end{array}$ & $\begin{array}{l}\text { Cross-section } \\
\text { (year 1989). }\end{array}$ & Correlation & $\begin{array}{l}\text { The authors observe that } \\
\text { bad environmental } \\
\text { performance is negatively } \\
\text { correlated with the } \\
\text { intangible asset value of } \\
\text { firms. They find that a }\end{array}$ \\
\hline
\end{tabular}




\begin{tabular}{|c|c|c|c|c|c|c|}
\hline & $\begin{array}{l}\text { pending against the firm } \\
\text { in } 1989 .\end{array}$ & & $\begin{array}{l}\text { share and concentration } \\
\text { data from Ward's Business } \\
\text { Directory (commercial), } \\
\text { R\&D expenditures using } \\
\text { data from the Disclosure } \\
\text { database, advertising } \\
\text { expenditures (ADVAL89) } \\
\text { were taken from data } \\
\text { published by the Arbitron } \\
\text { Company, the number of } \\
\text { environmental law suits } \\
\text { pending and toxic } \\
\text { emissions data from } \\
\text { Investor Responsibility } \\
\text { Research Center } \\
\text { (commercial). }\end{array}$ & & & $\begin{array}{l}10 \% \text { reduction in } \\
\text { emissions of toxic } \\
\text { chemicals results in a } \\
\text { US } \$ 34 \text { million increase in } \\
\text { market value. Their } \\
\text { evidence suggests that } \\
\text { firms are rewarded in the } \\
\text { marketplace for over- } \\
\text { complying with } \\
\text { environmental regulation } \\
\text { and for externally } \\
\text { portraying an image of } \\
\text { being environmentally } \\
\text { concerned. }\end{array}$ \\
\hline $\begin{array}{l}\text { Rassier and } \\
\text { Earnhart, } \\
2010 \mathrm{a}\end{array}$ & $\begin{array}{l}\text { Permitted wastewater } \\
\text { discharge limits for } \\
\text { BOD (biochemical } \\
\text { oxygen demand) and } \\
\text { TSS (total suspended } \\
\text { solids). }\end{array}$ & $\begin{array}{l}\text { Profitability as } \\
\text { measured by } \\
\text { returns on sales } \\
\text { (ROS). }\end{array}$ & $\begin{array}{l}\text { Publicly held chemical } \\
\text { manufacturing firms. The } \\
\text { sample of annual data } \\
\text { contains } 337 \text { observations, } \\
\text { consisting of } 73 \text { chemical } \\
\text { manufacturing firms. The } \\
\text { sample panel of quarterly } \\
\text { data contains } 926 \\
\text { observations, consisting of } \\
59 \text { chemical manufacturing } \\
\text { firms. } \\
\text { US EPA's Permit } \\
\text { Compliance System (PCS) } \\
\text { database for permitted } \\
\text { discharge limits (public), } \\
\text { S\&P Compustat for } \\
\text { financial data, PCS } \\
\text { database for facility level } \\
\text { environmental data } \\
\text { (commercial). }\end{array}$ & $\begin{array}{l}\text { Panel (1995- } \\
\text { 2001) yearly } \\
\text { data. }\end{array}$ & Correlation & $\begin{array}{l}\text { The authors obtain } \\
\text { consistent results across } \\
\text { both of their samples. A } \\
10 \% \text { reduction in the } \\
\text { average relative permitted } \\
\text { discharge limit causes the } \\
\text { return on sales to decrease } \\
\text { by as little as } 0.8 \% \text { and as } \\
\text { much as } 2.7 \% \text { according } \\
\text { to the } 90 \% \text { confidence } \\
\text { interval of the estimated } \\
\text { coefficient on the } \\
\text { discharge limit }\end{array}$ \\
\hline
\end{tabular}




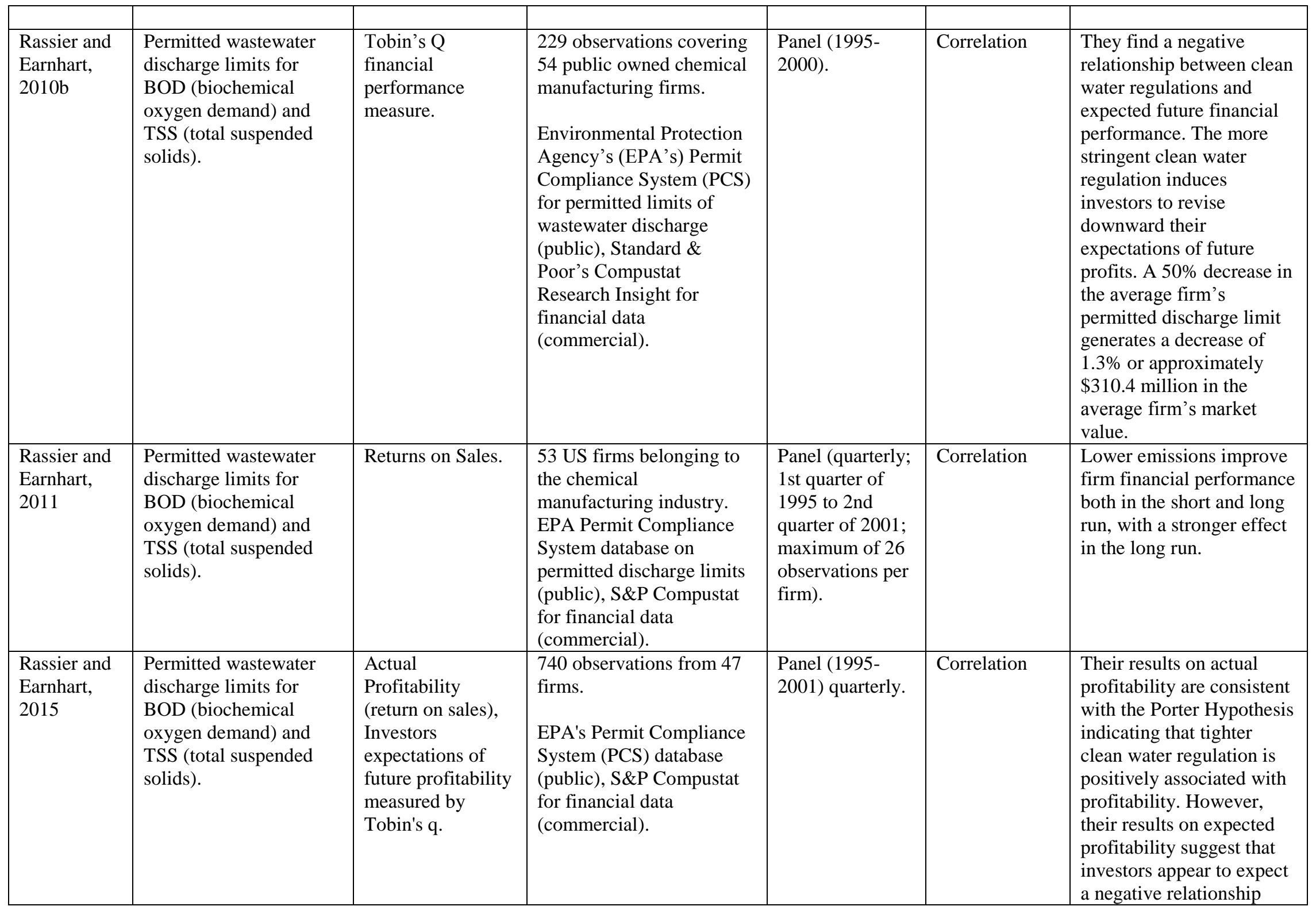




\begin{tabular}{|c|c|c|c|c|c|c|}
\hline & & & & & & $\begin{array}{l}\text { between clean water } \\
\text { regulation and } \\
\text { profitability. }\end{array}$ \\
\hline $\begin{array}{l}\text { Sanchez- } \\
\text { Vargas et al. } \\
(2013)\end{array}$ & $\begin{array}{l}\text { Environmental } \\
\text { regulation (as measured } \\
\text { by plant's pollution } \\
\text { abatement } \\
\text { expenditures). }\end{array}$ & Productivity & $\begin{array}{l}903 \text { observations of } \\
\text { Mexican firms. } \\
\text { Data from the national } \\
\text { industrial survey in } \\
\text { Mexico by the Mexican } \\
\text { Statistics agency (licence). }\end{array}$ & $\begin{array}{l}\text { Cross-section } \\
(2002) .\end{array}$ & Correlation & $\begin{array}{l}\text { They find a non-linear } \\
\text { relationship between } \\
\text { environmental regulation } \\
\text { and productivity. They } \\
\text { find that a decreasing } \\
\text { trade-off between } \\
\text { productivity and } \\
\text { environmental regulation. } \\
\text { Moreover, the relationship } \\
\text { depends on the plant size } \\
\text { and the trade-off is more } \\
\text { important for small firms } \\
\text { and a nearly negligible } \\
\text { one for larger ones. }\end{array}$ \\
\hline $\begin{array}{l}\text { Shadbegian } \\
\text { and Gray, } \\
2003\end{array}$ & $\begin{array}{l}\text { Air pollution } \\
\text { (Particulate Matter, } \\
\text { Sulphur Dioxide) per } \\
\text { unit of output. }\end{array}$ & Productivity & $\begin{array}{l}68 \text { US pulp and paper } \\
\text { mills. } \\
\text { Longitudinal Research } \\
\text { Database (LRD) (licence), } \\
\text { PACE for pollution } \\
\text { abatement costs (licence). }\end{array}$ & $\begin{array}{l}\text { Cross-section } \\
\text { (year 1985). }\end{array}$ & Correlation & $\begin{array}{l}\text { The authors analyse the } \\
\text { link between firm } \\
\text { productivity and pollution } \\
\text { abatement. They find that } \\
\text { plants with a } 10 \text { percent } \\
\text { higher productivity have } \\
2.5 \text { percent lower } \\
\text { emissions, suggesting that } \\
\text { productive efficiency and } \\
\text { pollution abatement } \\
\text { efficiency are } \\
\text { complements. Better } \\
\text { managers are better at } \\
\text { both production and } \\
\text { abatement, rather than } \\
\text { concentrating on } \\
\text { productive efficiency at } \\
\text { the expense of abatement } \\
\text { performance. }\end{array}$ \\
\hline Telle, 2006 & $\begin{array}{l}\text { Plant-level pollution } \\
\text { intensity calculated } \\
\text { from an aggregate }\end{array}$ & $\begin{array}{l}\text { Return-on-Sales } \\
\text { (ROS) (calculated } \\
\text { as Sales minus }\end{array}$ & $\begin{array}{l}1012 \text { plant-years from } \\
\text { manufacturing plants. }\end{array}$ & $\begin{array}{l}\text { Panel (1990- } \\
\text { 2001). }\end{array}$ & Correlation & $\begin{array}{l}\text { In the pooled regression, } \\
\text { which just controls for } \\
\text { observable plant }\end{array}$ \\
\hline
\end{tabular}




\begin{tabular}{|c|c|c|c|c|c|c|}
\hline & $\begin{array}{l}\text { pollution index } \\
\text { consisting of GHGs, } \\
\text { acids, particles and } \\
\text { ozone precursors } \\
\text { (nmvoc-equivalents). }\end{array}$ & $\begin{array}{l}\text { variable } \\
\text { production costs } \\
\text { divided by sales). }\end{array}$ & $\begin{array}{l}\text { Pollution data from the } \\
\text { Norwegian Pollution } \\
\text { Control Agency (NPCA) } \\
\text { (licence), Economic } \\
\text { performance data } \\
\text { (production, production } \\
\text { costs, employees, gross } \\
\text { investment) from Statistics } \\
\text { Norway (licence) }\end{array}$ & & & $\begin{array}{l}\text { characteristics, the author } \\
\text { finds that environmental } \\
\text { performance is positively } \\
\text { and significantly } \\
\text { associated with economic } \\
\text { performance. However, } \\
\text { when controlling for } \\
\text { unobservable plant } \\
\text { heterogeneity using plant } \\
\text { fixed effects, the effects } \\
\text { are no longer significant. }\end{array}$ \\
\hline $\begin{array}{l}\text { Trumpp and } \\
\text { Guenther, } \\
2017\end{array}$ & $\begin{array}{l}\text { Carbon performance } \\
\text { (negative GHG } \\
\text { emissions divided by } \\
\text { sales), Waste intensity } \\
\text { (negative amount of } \\
\text { waste produced by a } \\
\text { firm divided by sales). }\end{array}$ & $\begin{array}{l}\text { Profitability } \\
\text { (Return over } \\
\text { assets), stock } \\
\text { market } \\
\text { performance } \\
\text { (annual change in } \\
\text { stock prices plus } \\
\text { dividends). }\end{array}$ & $\begin{array}{l}2361 \text { firm-years. } \\
\text { GHG emissions from } \\
\text { Carbon Disclosure Project } \\
\text { (public), waste intensity } \\
\text { and financial data from } \\
\text { Thomson Reuter's } \\
\text { ASSET4 database } \\
\text { (commercial). }\end{array}$ & $\begin{array}{l}\text { Panel (2008- } \\
\text { 2012). }\end{array}$ & correlation & $\begin{array}{l}\text { They find a non-linear U- } \\
\text { shaped relationship } \\
\text { between carbon } \\
\text { performance and } \\
\text { profitability, as well as } \\
\text { between waste intensity } \\
\text { and profitability. Thus, } \\
\text { within their sample firms } \\
\text { with a low corporate } \\
\text { environmental } \\
\text { performance (CEP) tend to } \\
\text { have a negative } \\
\text { relationship with corporate } \\
\text { financial performance } \\
\text { (CFP), whereas firms at } \\
\text { high levels of CEP have a } \\
\text { positive relationship with } \\
\text { CFP. }\end{array}$ \\
\hline $\begin{array}{l}\text { Wagner and } \\
\text { Blom, } 2011\end{array}$ & $\begin{array}{l}\text { Environmental } \\
\text { Management Systems } \\
(\text { EMS). }\end{array}$ & $\begin{array}{l}\text { Firms' financial } \\
\text { performance } \\
\text { (Return on Sales). }\end{array}$ & $\begin{array}{l}497 \text { firms from Germany } \\
\text { and the UK. } \\
\text { Survey conducted by } \\
\text { authors on EMS system, } \\
\text { financial data from } \\
\text { AMADEUS database } \\
\text { (commercial). }\end{array}$ & $\begin{array}{l}\text { Cross-section } \\
\text { (survey } \\
\text { conducted in } \\
\text { 2001). }\end{array}$ & Correlation & $\begin{array}{l}\text { The authors use the } \\
\text { implementation of an } \\
\text { Environmental } \\
\text { Management System } \\
\text { (EMS) for firms' level of } \\
\text { sustainability. They find a } \\
\text { positive association } \\
\text { between the }\end{array}$ \\
\hline
\end{tabular}




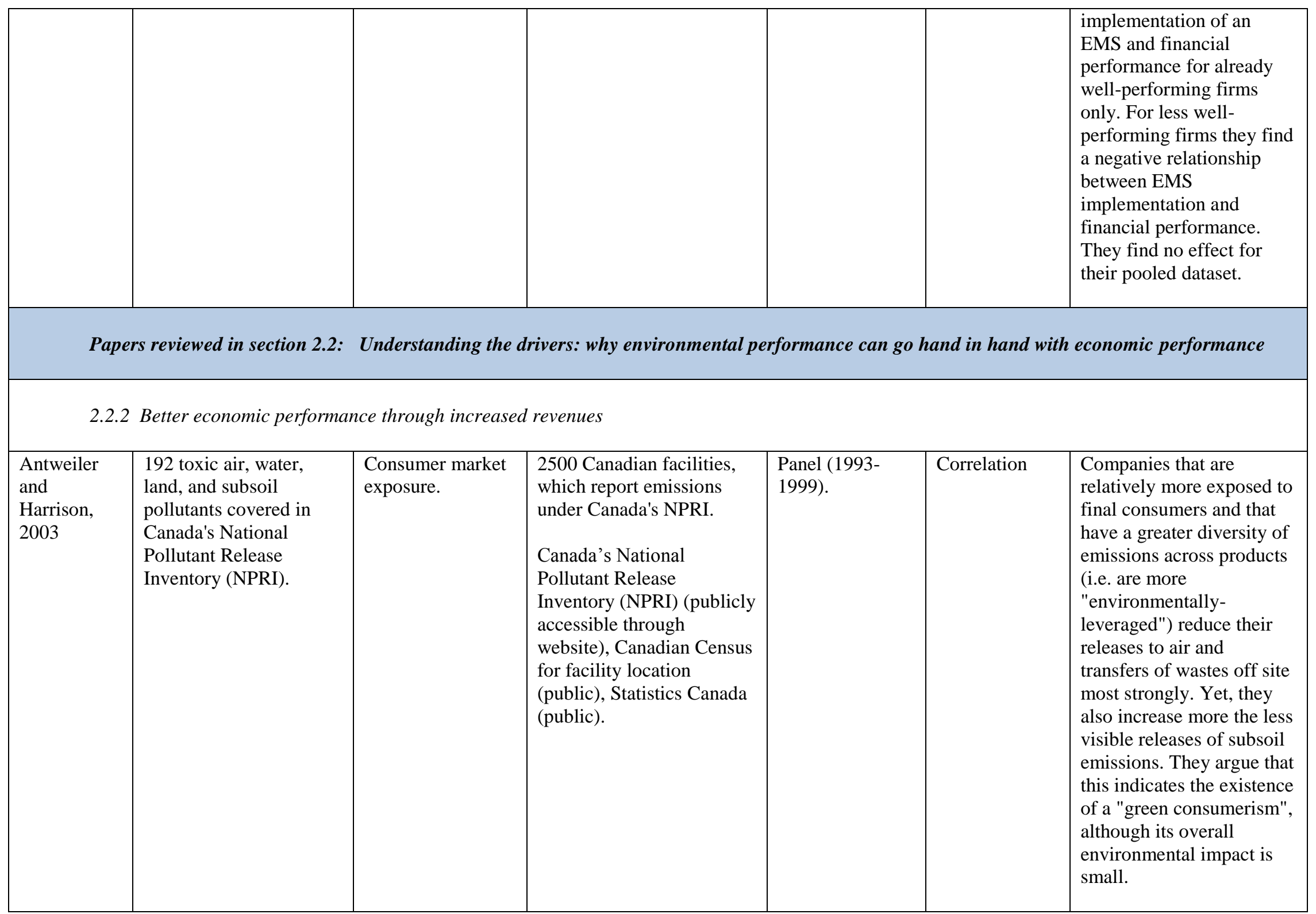




\begin{tabular}{|c|c|c|c|c|c|c|}
\hline $\begin{array}{l}\text { Horbach, } \\
2010\end{array}$ & $\begin{array}{l}\text { Environmental product } \\
\text { innovations. }\end{array}$ & $\begin{array}{l}\text { Employment at } \\
\text { the firm level. }\end{array}$ & $\begin{array}{l}900 \text { German firms } \\
\text { operating in environmental } \\
\text { sectors; } 12.400 \text { German } \\
\text { firms operating in non- } \\
\text { environmental fields. } \\
\text { Establishment panel of the } \\
\text { Institute for Employment } \\
\text { Research Nuremberg } \\
\text { (licence). }\end{array}$ & $\begin{array}{l}\text { Panel (2002- } \\
\text { 2005). }\end{array}$ & Correlation & $\begin{array}{l}\text { Firms in the } \\
\text { environmental sector that } \\
\text { developed new or } \\
\text { modified products from } \\
2002 \text { to } 2003 \text { increased } \\
\text { their employment from } \\
2003 \text { to } 2005 . \text { The } \\
\text { employment impact of } \\
\text { innovation is larger than } \\
\text { for firms in non- } \\
\text { environmental sectors. }\end{array}$ \\
\hline $\begin{array}{l}\text { Palmer and } \\
\text { Truong, } \\
2017\end{array}$ & $\begin{array}{l}\text { Technological green } \\
\text { product introductions } \\
(\mathrm{NPI}) .\end{array}$ & $\begin{array}{l}\text { Firm profitability } \\
\text { measured by } \\
\text { turnover and } \\
\text { return on capital. }\end{array}$ & $\begin{array}{l}79 \text { global firms (1020 } \\
\text { technological green } \\
\text { product introductions. } \\
\text { Authors constructed the } \\
\text { dataset of NPIs based on } \\
\text { press releases. }\end{array}$ & $\begin{array}{l}\text { Panel (2007- } \\
\text { 2012). }\end{array}$ & Correlation & $\begin{array}{l}\text { They find a significant } \\
\text { positive correlation } \\
\text { between technology-based } \\
\text { green new product } \\
\text { introductions (NPI) and } \\
\text { short term profitability } \\
\text { measured by turnover or } \\
\text { return on capital. They } \\
\text { also find a weakly } \\
\text { significant relationship } \\
\text { when using the ratio of } \\
\text { technological green NPIs } \\
\text { to the total number of } \\
\text { NPIs. This finding might } \\
\text { suggest that a higher share } \\
\text { of green products is } \\
\text { associated with extra } \\
\text { profitability. }\end{array}$ \\
\hline $\begin{array}{l}\text { Rennings } \\
\text { and Zwick, } \\
2002\end{array}$ & $\begin{array}{l}\text { Introduction of new } \\
\text { environmental products; } \\
\text { environmental } \\
\text { innovations. }\end{array}$ & $\begin{array}{l}\text { Employment at } \\
\text { the firm level. }\end{array}$ & $\begin{array}{l}1594 \text { interviews of } \\
\text { environmentally } \\
\text { innovative industry and } \\
\text { services firms from } \\
\text { Germany, Italy, } \\
\text { Switzerland, UK, and } \\
\text { Netherlands. The firms } \\
\text { span across } 8 \text { NACE } \\
\text { sectors (D-K). Firms were }\end{array}$ & $\begin{array}{l}\text { Cross-section } \\
\text { (interviews were } \\
\text { carried out in } \\
\text { 2000). }\end{array}$ & Correlation & $\begin{array}{l}\text { Environmental } \\
\text { innovations have a small } \\
\text { but positive effect on } \\
\text { employment at the firm } \\
\text { level. Product and service } \\
\text { innovation generate more } \\
\text { jobs than process } \\
\text { innovations. Employment } \\
\text { impacts differ according to }\end{array}$ \\
\hline
\end{tabular}




\begin{tabular}{|c|c|c|c|c|c|c|}
\hline & & & $\begin{array}{l}\text { only included if they self- } \\
\text { reported to have done at } \\
\text { least one environmental } \\
\text { innovation in the past three } \\
\text { years. } \\
\text { Survey conducted by } \\
\text { authors. }\end{array}$ & & & $\begin{array}{l}\text { the intended goals of the } \\
\text { innovation: If they are } \\
\text { motivated by cost } \\
\text { reduction, they tend to } \\
\text { reduce employment. If } \\
\text { they are motivated by } \\
\text { goals to increase the } \\
\text { market share, the effect } \\
\text { can be positive or } \\
\text { negative. }\end{array}$ \\
\hline $\begin{array}{l}\text { Rennings et } \\
\text { al., } 2004\end{array}$ & $\begin{array}{l}\text { Environmental } \\
\text { Innovations. }\end{array}$ & $\begin{array}{l}\text { Employment at } \\
\text { the firm level. }\end{array}$ & $\begin{array}{l}1594 \text { interviews of } \\
\text { environmentally } \\
\text { innovative industry and } \\
\text { services firms from } \\
\text { Germany, Italy, } \\
\text { Switzerland, UK, and } \\
\text { Netherlands. The firms } \\
\text { span across } 8 \text { NACE } \\
\text { sectors (D-K). Firms were } \\
\text { only included if they self- } \\
\text { reported to have done at } \\
\text { least one environmental } \\
\text { innovation in the past three } \\
\text { years. } \\
\text { Survey conducted by } \\
\text { authors. }\end{array}$ & $\begin{array}{l}\text { Cross-section } \\
\text { (interviews were } \\
\text { carried out in } \\
\text { 2000). }\end{array}$ & Correlation & $\begin{array}{l}\text { Environmental product } \\
\text { and service innovations } \\
\text { increase the likelihood that } \\
\text { the firm increases its } \\
\text { employment base. Yet } \\
\text { environmental end-of-pipe } \\
\text { innovations increase the } \\
\text { likelihood that the firm } \\
\text { decreases its employment } \\
\text { base. }\end{array}$ \\
\hline \multicolumn{7}{|c|}{ Energy and materials } \\
\hline $\begin{array}{l}\text { Bloom et } \\
\text { al., } 2010\end{array}$ & Energy Intensity. & $\begin{array}{l}\text { Total factor } \\
\text { productivity, } \\
\text { Quality of } \\
\text { management. }\end{array}$ & $\begin{array}{l}300 \text { manufacturing firms } \\
\text { in the UK. } \\
\text { UK establishment-level } \\
\text { Census of Production data } \\
\text { from the UK ONS }\end{array}$ & $\begin{array}{l}\text { Cross-section } \\
\text { (Management } \\
\text { Survey Data } \\
\text { from 2006). }\end{array}$ & Correlation & $\begin{array}{l}\text { They find a robust } \\
\text { negative relationship } \\
\text { between management } \\
\text { practices and energy } \\
\text { intensity. Improving } \\
\text { management practices }\end{array}$ \\
\hline
\end{tabular}




\begin{tabular}{|c|c|c|c|c|c|c|}
\hline & & & $\begin{array}{l}\text { (license), survey collected } \\
\text { by Center for Economic } \\
\text { Performance (CEP). }\end{array}$ & & & $\begin{array}{l}\text { from the } 25 \text { th to the } 75 \text { th } \\
\text { percentile is associated } \\
\text { with a } 17.4 \% \text { reduction in } \\
\text { energy intensity and with } \\
\text { a } 3.7 \% \text { increase in total- } \\
\text { factor productivity. They } \\
\text { also find that better } \\
\text { economic performance as } \\
\text { measured by TFP is } \\
\text { associated with lower } \\
\text { energy intensity. The } \\
\text { results suggest that } \\
\text { management practices that } \\
\text { are associated with } \\
\text { improved productivity are } \\
\text { not linked to worse } \\
\text { environmental } \\
\text { performance. }\end{array}$ \\
\hline
\end{tabular}




\begin{tabular}{|c|c|c|c|c|c|c|}
\hline & & & & & & $\begin{array}{l}\text { airline over the eight- } \\
\text { month experimental } \\
\text { period ( } \$ 6.1 \text { million in } \\
2014 \text { prices), which } \\
\text { translates to about } 24.500 \\
\text { tons of } \mathrm{CO}_{2} \text { abated. They } \\
\text { estimate a marginal } \\
\text { abatement cost per ton of } \\
\mathrm{CO}_{2} \text { at negative } \$ 250 \text { (i.e. } \\
\$ 250 \text { savings per ton } \\
\text { abated) from } \\
\text { implementing the low-cost } \\
\text { behavioural interventions, } \\
\text { which is the lowest } \\
\text { marginal abatement cost } \\
\text { so far calculated in the } \\
\text { literature. }\end{array}$ \\
\hline $\begin{array}{l}\text { Horbach and } \\
\text { Rennings, } \\
2013\end{array}$ & $\begin{array}{l}\text { Cleaner Production } \\
\text { innovations, } \\
\text { Environmental end-of- } \\
\text { pipe innovations. }\end{array}$ & $\begin{array}{l}\text { Employment at } \\
\text { the firm level. }\end{array}$ & $\begin{array}{l}\text { Between } 3700 \text { and } 4500 \\
\text { German firms from the } \\
\text { Community Innovation } \\
\text { Survey (CIS), covering } \\
\text { mining and quarrying, } \\
\text { manufacturing, energy and } \\
\text { water supply, large number } \\
\text { of service sectors (licence). } \\
2009 \text { wave of the German } \\
\text { Community Innovation } \\
\text { Survey (CIS) (licence). }\end{array}$ & $\begin{array}{l}\text { Cross-section } \\
\text { (Community } \\
\text { Innovation } \\
\text { Survey 2009). }\end{array}$ & Correlation & $\begin{array}{l}\text { The realization of } \\
\text { environmental process } \\
\text { innovations leads to a } \\
\text { higher employment within } \\
\text { the firm. Furthermore, } \\
\text { material and energy } \\
\text { savings are positively } \\
\text { correlated to employment } \\
\text { because they help to } \\
\text { increase the profitability } \\
\text { and competitiveness of the } \\
\text { firm. Yet, end-of-pipe } \\
\text { technologies (in particular } \\
\text { air and water process } \\
\text { innovations) have a } \\
\text { negative impact on } \\
\text { employment. }\end{array}$ \\
\hline
\end{tabular}




\begin{tabular}{|c|c|c|c|c|c|c|}
\hline $\begin{array}{l}\text { Kumar and } \\
\text { Managi, } \\
2010\end{array}$ & $\mathrm{SO}_{2}$ emissions price. & $\begin{array}{l}\text { Innovation } \\
\text { activity. }\end{array}$ & $\begin{array}{l}50 \text { electricity generating } \\
\text { plants. } \\
\text { Federal Energy Regulatory } \\
\text { Commission (FERC) for } \\
\text { electricity production at } \\
\text { the plant level, employees } \\
\text { and capital stock (licence), } \\
\text { US EPA Aerometric } \\
\text { Information Retrieval } \\
\text { System (AIRS) database } \\
\text { for } \mathrm{SO}_{2} \text { emissions and } \\
\text { emissions prices (public). }\end{array}$ & $\begin{array}{l}\text { Panel (1995- } \\
\text { 2007). }\end{array}$ & Correlation & $\begin{array}{l}\text { The authors have tested } \\
\text { whether an increase in } \\
\mathrm{SO}_{2} \text { emissions prices leads } \\
\text { to a reduction in pollution } \\
\text { emissions. They observe } \\
\text { that electricity generating } \\
\text { plants experience positive } \\
\text { induced technological } \\
\text { change. Electricity- } \\
\text { generating plants are able } \\
\text { to increase electricity } \\
\text { output and reduce } \\
\text { emissions of } \mathrm{SO}_{2} \text { and NOx } \\
\text { from } 1995 \text { to } 2007 \text { due to } \\
\text { the introduction of the } \\
\text { allowance trading system. }\end{array}$ \\
\hline $\begin{array}{l}\text { Martin et } \\
\text { al., } 2012\end{array}$ & $\begin{array}{l}\text { Energy intensity (energy } \\
\text { expenditure / gross } \\
\text { output) and (energy } \\
\text { intensity / variable cost); } \\
\text { Composite Index on } \\
\text { management practices } \\
\text { related to climate } \\
\text { change collected } \\
\text { through interviews. }\end{array}$ & Productivity & $\begin{array}{l}\text { 190 UK manufacturing } \\
\text { plants. } \\
\text { ORBIS database for } \\
\text { random selection of UK } \\
\text { manufacturing plants } \\
\text { (commercial). Survey data } \\
\text { collected by authors. }\end{array}$ & $\begin{array}{l}\text { Cross-section } \\
\text { (interview data } \\
\text { collected in } \\
\text { 2009). }\end{array}$ & Correlation & $\begin{array}{l}\text { Climate friendly } \\
\text { management practices, as } \\
\text { measured by an index } \\
\text { constructed from survey } \\
\text { responses are associated } \\
\text { with lower energy } \\
\text { intensity and higher } \\
\text { productivity at the } \\
\text { establishment level. They } \\
\text { suggest that there might be } \\
\text { a win-win scenario from } \\
\text { improving environmental } \\
\text { management, which could } \\
\text { also raise firm } \\
\text { productivity. }\end{array}$ \\
\hline $\begin{array}{l}\text { Pfeiffer and } \\
\text { Rennings, } \\
2001\end{array}$ & $\begin{array}{l}\text { Environmental } \\
\text { Innovations. }\end{array}$ & $\begin{array}{l}\text { Employment at } \\
\text { the firm level. }\end{array}$ & $\begin{array}{l}419 \text { German } \\
\text { environmentally } \\
\text { innovative manufacturing } \\
\text { firms (a company was } \\
\text { defined as such if it carried } \\
\text { out at least one } \\
\text { environmental innovation } \\
\text { between } 1993 \text { and 1995). }\end{array}$ & $\begin{array}{l}\text { Cross-section } \\
\text { (1996 wave of } \\
\text { the Mannheim } \\
\text { Innovation } \\
\text { Panel). }\end{array}$ & Correlation & $\begin{array}{l}\text { Cleaner production } \\
\text { processes are more likely } \\
\text { to increase employment } \\
\text { compared to end-of-pipe } \\
\text { technologies. The authors } \\
\text { conclude that the } \\
\text { transition from end-of- } \\
\text { pipe technologies to }\end{array}$ \\
\hline
\end{tabular}




\begin{tabular}{|c|c|c|c|c|c|c|}
\hline & & & $\begin{array}{l}\text { Survey of the Mannheim } \\
\text { Innovation Panel (licence). }\end{array}$ & & & $\begin{array}{l}\text { cleaner production can } \\
\text { lead to a net creation of } \\
\text { jobs. }\end{array}$ \\
\hline $\begin{array}{l}\text { Shadbegian } \\
\text { and Gray, } \\
2005\end{array}$ & $\begin{array}{l}\text { Pollution abatement } \\
\text { expenditure. }\end{array}$ & Productivity & $\begin{array}{l}68 \text { US pulp and paper } \\
\text { mills, } 55 \text { oil refineries, and } \\
27 \text { steel mills. } \\
\text { Longitudinal Research } \\
\text { Database (LRD) for } \\
\text { economic outcomes } \\
\text { (licence), } \\
\text { PACE for pollution } \\
\text { abatement costs (licence). }\end{array}$ & $\begin{array}{l}\text { Panel (1979- } \\
\text { 1990). }\end{array}$ & Correlation & $\begin{array}{l}\text { The authors analyse the } \\
\text { impact of traditional } \\
\text { environmental regulation } \\
\text { on productivity in U.S. } \\
\text { paper mills, oil refineries, } \\
\text { and steel mills. They find } \\
\text { that pollution abatement } \\
\text { contributes little or } \\
\text { nothing to firms' } \\
\text { productivity. }\end{array}$ \\
\hline $\begin{array}{l}\text { Shadbegian } \\
\text { and Gray, } \\
2006\end{array}$ & $\begin{array}{l}\text { Air pollution } \\
\text { (Particulate Matter, } \\
\text { Sulphur Dioxide), water } \\
\text { pollution (biological } \\
\text { oxygen demand, total } \\
\text { suspended solids), toxic } \\
\text { releases; all in per unit } \\
\text { of plant output. }\end{array}$ & $\begin{array}{l}\text { Production } \\
\text { efficiency } \\
\text { (measured through } \\
\text { stochastic frontier } \\
\text { production } \\
\text { models). }\end{array}$ & $\begin{array}{l}\text { plants in } 327 \text { pulp and } \\
\text { paper mills, } 121 \text { oil } \\
\text { refineries, and } 83 \text { steel } \\
\text { mills; } \\
\text { Longitudinal Research } \\
\text { Database (LRD) (licence), } \\
\text { Census Bureau's Boston } \\
\text { Research Data Center } \\
\text { (licence), } \\
\text { Firm financial data from } \\
\text { Compustat, PACE survey } \\
\text { for abatement costs, } \\
\text { environmental } \\
\text { performance measures } \\
\text { come from several EPA } \\
\text { databases (licence): } \\
\text { National Emissions } \\
\text { Inventory (NEI), Permit } \\
\text { Compliance System } \\
\text { (PCS), Toxic Release } \\
\text { Inventory (TRI), and } \\
\text { Compliance Data System } \\
\text { (CDS) (public). }\end{array}$ & $\begin{array}{l}\text { Panel (1990- } \\
\text { 2000). }\end{array}$ & Correlation & $\begin{array}{l}\text { There is a positive } \\
\text { correlation between the } \\
\text { environmental and } \\
\text { economic performance at } \\
\text { the plant level. The } \\
\text { finding suggests the } \\
\text { importance of unmeasured } \\
\text { characteristics that } \\
\text { improve both the plant's } \\
\text { environmental } \\
\text { performance and its } \\
\text { economic performance. }\end{array}$ \\
\hline $\begin{array}{l}\text { van } \\
\text { Leeuwen } \\
\text { and }\end{array}$ & $\begin{array}{l}\text { Eco-innovations } \\
\text { (process-, and end-of- } \\
\text { pipe). }\end{array}$ & $\begin{array}{l}\text { Total factor } \\
\text { productivity. }\end{array}$ & $\begin{array}{l}\text { Approximately } 2000 \\
\text { Dutch manufacturing } \\
\text { firms. }\end{array}$ & $\begin{array}{l}\text { Panel (2003- } \\
\text { 2008) yearly, but } \\
\text { with imputation. }\end{array}$ & Correlation & $\begin{array}{l}\text { There is a significantly } \\
\text { positive correlation } \\
\text { between existing or }\end{array}$ \\
\hline
\end{tabular}




\begin{tabular}{|c|c|c|}
\hline $\begin{array}{l}\text { Mohnen, } \\
2017\end{array}$ & $\begin{array}{l}\text { Environmental Cost of } \\
\text { Firms (ECF) survey for } \\
\text { eco-innovations, } \\
\text { Community Innovation } \\
\text { Survey (CIS) for existence } \\
\text { or anticipation of } \\
\text { environmental regulation } \\
\text { and for environmental } \\
\text { innovation targets } \\
\text { (licence), Production } \\
\text { Statistics Survey for } \\
\text { production and financial } \\
\text { firm data (licence). }\end{array}$ & $\begin{array}{l}\text { anticipated environmental } \\
\text { regulation and eco- } \\
\text { innovations. Moreover, } \\
\text { they observe that } \\
\text { production process eco- } \\
\text { innovations are positively } \\
\text { correlated with firms' } \\
\text { productivity, whereas end- } \\
\text { of-pipe innovations are } \\
\text { negatively correlated with } \\
\text { firms' productivity. }\end{array}$ \\
\hline
\end{tabular}


Labour costs

\begin{tabular}{|c|c|c|c|c|c|c|}
\hline $\begin{array}{l}\text { Delmas and } \\
\text { Pekovic, } \\
2013\end{array}$ & $\begin{array}{l}\text { Adoption of } \\
\text { environmental standards } \\
\text { (ISO14001, organic } \\
\text { labelling, fair trade } \\
\text { labelling, other types of } \\
\text { environmental-related } \\
\text { standards). }\end{array}$ & $\begin{array}{l}\text { Labour } \\
\text { productivity. }\end{array}$ & $\begin{array}{l}10.663 \text { employees from } \\
5220 \text { firms. } \\
\text { French Organizational } \\
\text { Changes and } \\
\text { Computerization (COI) } \\
2006 \text { survey, Annual } \\
\text { Enterprise Survey (EAE), } \\
\text { Annual Statement of } \\
\text { Social Data (DADS) } \\
\text { (licence). }\end{array}$ & $\begin{array}{l}\text { Cross-section } \\
(2006) .\end{array}$ & Correlation & $\begin{array}{l}\text { Firms that have adopted } \\
\text { environmental standards } \\
\text { enjoy a one standard } \\
\text { deviation higher labour } \\
\text { productivity compared to } \\
\text { firms that have not } \\
\text { adopted such standards. } \\
\text { Furthermore, the adoption } \\
\text { of such standards is } \\
\text { associated with increased } \\
\text { employee training and } \\
\text { interpersonal contacts, } \\
\text { which can in turn } \\
\text { contribute to improved } \\
\text { labour productivity. }\end{array}$ \\
\hline $\begin{array}{l}\text { Grolleau et } \\
\text { al., } 2012\end{array}$ & $\begin{array}{l}\text { Adoption of } \\
\text { environmental standards } \\
\text { (ISO14001, organic } \\
\text { labelling, fair trade } \\
\text { labelling, other types of } \\
\text { environmental-related } \\
\text { standards). }\end{array}$ & $\begin{array}{l}\text { Self-reported } \\
\text { difficulties in } \\
\text { recruiting } \\
\text { professional and } \\
\text { non-professional } \\
\text { staff. }\end{array}$ & $\begin{array}{l}10.840 \text { French firms. } \\
\text { French Organizational } \\
\text { Changes and } \\
\text { Computerization's (COI) } \\
2006 \text { survey, Annual } \\
\text { Statement of Social Data } \\
\text { (DADS) and the Annual } \\
\text { Enterprise Survey (EAE) } \\
\text { for information on wages } \\
\text { and export respectively } \\
\text { (licence). }\end{array}$ & $\begin{array}{l}\text { Cross-section } \\
(2006) .\end{array}$ & Correlation & $\begin{array}{l}\text { The adoption of voluntary } \\
\text { environmental standards is } \\
\text { associated with reduced } \\
\text { self-reported difficulties in } \\
\text { the recruitment of } \\
\text { professional and non- } \\
\text { professional employees. }\end{array}$ \\
\hline $\begin{array}{l}\text { Lanfranchi } \\
\text { and } \\
\text { Pekovic, } \\
2012\end{array}$ & $\begin{array}{l}\text { Firm registration with at } \\
\text { least one environmental } \\
\text { standard (ISO14001, } \\
\text { organic labelling or fair } \\
\text { trade labelling). }\end{array}$ & $\begin{array}{l}\text { Self-reported } \\
\text { employee attitudes } \\
\text { (usefulness to } \\
\text { others, equitable } \\
\text { recognition for } \\
\text { work, employee's } \\
\text { involvement, } \\
\text { absence of } \\
\text { compensation for }\end{array}$ & $\begin{array}{l}11600 \text { employees at } 7700 \\
\text { French firms from a } \\
\text { representative French } \\
\text { employer-employee } \\
\text { dataset of firms with more } \\
\text { than } 20 \text { employees. } \\
\text { French Organizational } \\
\text { Change and ICT's (COI) }\end{array}$ & $\begin{array}{l}\text { Cross-section } \\
\text { (2006 survey). }\end{array}$ & Correlation & $\begin{array}{l}\text { Employees of firms that } \\
\text { have adopted voluntary } \\
\text { environmental standards } \\
\text { report a significantly } \\
\text { higher feeling of } \\
\text { usefulness at work. Firms' } \\
\text { registration for } \\
\text { environmental-related } \\
\text { standards is associated } \\
\end{array}$ \\
\hline
\end{tabular}




\begin{tabular}{|c|c|c|c|c|c|c|}
\hline & & $\begin{array}{l}\text { supplementary } \\
\text { work hours). }\end{array}$ & $\begin{array}{l}2006 \text { survey, French } \\
\text { Organizational Change and } \\
\text { ICT's (COI) } 2006 \text { survey } \\
\text { for employee } \\
\text { compensation, Annual } \\
\text { Enterprise Survey (EAE) } \\
\text { for firm export levels } \\
\text { (licence). }\end{array}$ & & & $\begin{array}{l}\text { with higher feelings of } \\
\text { usefulness to others and } \\
\text { feelings of being equitably } \\
\text { recognized among the } \\
\text { employees. While the } \\
\text { employees do not claim to } \\
\text { be more involved in their } \\
\text { jobs, they are more likely } \\
\text { to work uncompensated } \\
\text { for supplementary work } \\
\text { hours compared to } \\
\text { workers in non-green } \\
\text { firms. }\end{array}$ \\
\hline $\begin{array}{l}\text { Nyborg and } \\
\text { Zhang, } 2013\end{array}$ & $\begin{array}{l}\text { Corporate Social } \\
\text { Responsibility (CSR) } \\
\text { reputation rating } \\
\text { collected through a } \\
\text { survey. Respondents } \\
\text { stated whether they } \\
\text { associate a given firm } \\
\text { with CSR activities. } \\
\text { This response was } \\
\text { combined with the } \\
\text { respondent's opinion on } \\
\text { whether they consider } \\
\text { the firm an "ideal } \\
\text { employer" to obtain a } \\
\text { relative CSR reputation } \\
\text { score. }\end{array}$ & Employee wages. & $\begin{array}{l}100.000 \text { Norwegian } \\
\text { employees. } \\
\text { Young Professionals } \\
\text { Survey and Graduate } \\
\text { Student survey conducted } \\
\text { by Universum } \\
\text { (commercial), official } \\
\text { Norwegian employee- } \\
\text { employer register for } \\
\text { wages (licence). }\end{array}$ & $\begin{array}{l}\text { Cross-section } \\
(2007) .\end{array}$ & Correlation & $\begin{array}{l}\text { Firms with higher CSR } \\
\text { ratings pay substantially } \\
\text { and significantly lower } \\
\text { wages. The authors } \\
\text { therefore conclude that } \\
\text { even if CSR is associated } \\
\text { with higher costs (e.g. } \\
\text { higher emission abatement } \\
\text { expenses), responsible } \\
\text { firms are still able to } \\
\text { compete in the market } \\
\text { even in the absence of } \\
\text { ethical consumers or } \\
\text { investors. }\end{array}$ \\
\hline \multicolumn{7}{|c|}{ Cost of capital } \\
\hline $\begin{array}{l}\text { Attig et al., } \\
2013\end{array}$ & $\begin{array}{l}\text { Corporate Social } \\
\text { Responsibility (CSR) } \\
\text { score provided by a } \\
\text { third party research } \\
\text { company. }\end{array}$ & $\begin{array}{l}\text { Firm credit ratings } \\
\text { (compiled by } \\
\text { S\&P). }\end{array}$ & $\begin{array}{l}1585 \text { US firms. } \\
\text { S\&P credit ratings, } \\
\text { Compustat, Center for } \\
\text { Research in Security } \\
\text { Prices database (CRSP), } \\
\text { Thompson's Institutional }\end{array}$ & $\begin{array}{l}\text { Panel (1991- } \\
\text { 2010). }\end{array}$ & Correlation & $\begin{array}{l}\text { The authors find a } \\
\text { significant positive impact } \\
\text { of CSR on firm credit } \\
\text { ratings. They suggest that } \\
\text { by investing in CSR, } \\
\text { firms' financing costs are } \\
\text { likely to decrease due to }\end{array}$ \\
\hline
\end{tabular}




\begin{tabular}{|c|c|c|c|c|c|c|}
\hline & & & $\begin{array}{l}\text { Brokers Estimate System, } \\
\text { MSCI ESG Stats } \\
\text { (commercial). }\end{array}$ & & & $\begin{array}{l}\text { the better credit rating, } \\
\text { which all else equal } \\
\text { should enhance firm value } \\
\text { and shareholders' value. }\end{array}$ \\
\hline $\begin{array}{l}\text { Cheng et al., } \\
2013\end{array}$ & $\begin{array}{l}\text { Corporate Social } \\
\text { Responsibility (CSR) } \\
\text { score provided by a } \\
\text { third party. }\end{array}$ & $\begin{array}{l}\text { Capital constraints } \\
\text { expressed through } \\
\text { five accounting } \\
\text { ratios: 1) cash } \\
\text { flow to total } \\
\text { capital, 2) market } \\
\text { to book ratio, 3) } \\
\text { debt to total } \\
\text { capital, 4) } \\
\text { dividends to total } \\
\text { capital, 5) cash } \\
\text { holdings to total } \\
\text { capital. }\end{array}$ & $\begin{array}{l}2439 \text { publicly listed firms } \\
\text { across } 49 \text { countries. } \\
\text { Thompson Reuters } \\
\text { ASSET4 database } \\
\text { (commercial). }\end{array}$ & $\begin{array}{l}\text { Panel (2002- } \\
\text { 2009). }\end{array}$ & Correlation & $\begin{array}{l}\text { Firms with better CSR } \\
\text { performance face lower } \\
\text { capital constraints. }\end{array}$ \\
\hline $\begin{array}{l}\text { El Ghoul et } \\
\text { al., } 2011\end{array}$ & $\begin{array}{l}\text { Corporate Social } \\
\text { Responsibility (CSR) } \\
\text { ratings provided by a } \\
\text { third party research } \\
\text { company. }\end{array}$ & $\begin{array}{l}\text { Ex-ante cost of } \\
\text { equity capital } \\
\text { implied in stock } \\
\text { prices and } \\
\text { analysts' earnings } \\
\text { forecasts. }\end{array}$ & $\begin{array}{l}2809 \text { US firms; } \\
\text { Thompson Institutional } \\
\text { Brokers Earnings Services } \\
\text { for analyst forecast data, } \\
\text { Compustat North America } \\
\text { for industry affiliation and } \\
\text { financial data, KLD } \\
\text { STATS for CSR data, } \\
\text { CRSP monthly return files } \\
\text { for stock returns } \\
\text { (commercial). }\end{array}$ & $\begin{array}{l}\text { Panel (1992- } \\
\text { 2007). }\end{array}$ & Correlation & $\begin{array}{l}\text { Firms with higher CSR } \\
\text { scores enjoy significantly } \\
\text { lower cost of equity } \\
\text { capital. The authors } \\
\text { conclude that improved } \\
\text { CSR can enhance firm } \\
\text { value by reducing the } \\
\text { firm's cost of equity } \\
\text { capital. They argue that } \\
\text { CSR activities can } \\
\text { enhance the company's } \\
\text { investor base by attracting } \\
\text { socially responsible } \\
\text { investors. }\end{array}$ \\
\hline $\begin{array}{l}\text { Goss and } \\
\text { Roberts, } \\
2011\end{array}$ & $\begin{array}{l}\text { Corporate Social } \\
\text { Responsibility (CSR) } \\
\text { ratings provided by a } \\
\text { third party. }\end{array}$ & $\begin{array}{l}\text { Spread basis } \\
\text { points (the amount } \\
\text { the borrower pays } \\
\text { over LIBOR for } \\
\text { each loan dollar). }\end{array}$ & $\begin{array}{l}3996 \text { loans to US firms. } \\
\text { KLD Research and } \\
\text { Analytics Inc. for measure } \\
\text { of social responsibility, } \\
\text { Compustat for financial } \\
\text { information, Thompson } \\
\text { CDA spectrum for }\end{array}$ & $\begin{array}{l}\text { Panel (1991- } \\
\text { 2006). }\end{array}$ & Correlation & $\begin{array}{l}\text { Firms with social } \\
\text { responsibility concerns } \\
\text { pay between } 7 \text { und } 18 \\
\text { basis points more than } \\
\text { firms that are more } \\
\text { responsible. Lenders } \\
\text { demand higher yield } \\
\text { spreads from borrowers }\end{array}$ \\
\hline
\end{tabular}




\begin{tabular}{|l|l|l|l|l|}
\hline & & $\begin{array}{l}\text { institutional ownership, } \\
\text { Dealscan for loan pricing } \\
\text { data (commercial). }\end{array}$ & $\begin{array}{l}\text { with the worst records in } \\
\text { social responsibility. Yet, } \\
\text { they recognize } \\
\text { greenwashing activities } \\
\text { and punish CSR activities } \\
\text { that are unlikely to add } \\
\text { value. }\end{array}$ \\
\hline
\end{tabular}


Papers reviewed in section 3: The impact of green growth policies on environmental and economic performance

3.1. The impact of green growth policies on economic outcomes

\begin{tabular}{|c|c|c|c|c|c|c|}
\hline $\begin{array}{l}\text { Albrizio et } \\
\text { al., } 2017\end{array}$ & $\begin{array}{l}\text { Environmental Policy } \\
\text { Stringency Index }\end{array}$ & $\begin{array}{l}\text { Productivity } \\
\text { Growth }\end{array}$ & $\begin{array}{l}191,597 \text { firms across } 22 \\
\text { manufacturing sectors in } \\
11 \text { OECD countries. } \\
\text { Firm MFP is constructed } \\
\text { using Orbis (commercial), } \\
\text { Industry productivity } \\
\text { growth is constructed from } \\
\text { OECD STAN and PDBi } \\
\text { database, Environmental } \\
\text { Policy Stringency Index } \\
\text { from the OECD (public). }\end{array}$ & $\begin{array}{l}\text { Panel(2000- } \\
\text { 2009) }\end{array}$ & Correlation & $\begin{array}{l}\text { A more stringent } \\
\text { environmental policy is } \\
\text { associated with a } \\
\text { productivity increase for } \\
\text { the most productive firms } \\
\text { and a productivity } \\
\text { slowdown for the less } \\
\text { productive ones. The } \\
\text { average firm experiences } \\
\text { no effect. }\end{array}$ \\
\hline $\begin{array}{l}\text { Dlugosch } \\
\text { and Kozluk, } \\
2017\end{array}$ & $\begin{array}{l}\text { Energy price inflation as } \\
\text { a proxy for } \\
\text { environmental policy } \\
\text { stringency, }\end{array}$ & $\begin{array}{l}\text { Firm-level } \\
\text { investment } \\
\text { (measured as } \\
\text { capital } \\
\text { expenditure } \\
\text { relative to capital } \\
\text { stock). }\end{array}$ & $\begin{array}{l}\text { 70,479 observations (firm- } \\
\text { years) from publicly listed } \\
\text { firms from } 30 \text { OECD } \\
\text { countries across } 10 \\
\text { manufacturing industries. } \\
\text { Financial data from } \\
\text { Worldscope (commercial) } \\
\text { and OECD STAN } \\
\text { database, Energy Price } \\
\text { index from Sato et al. } \\
\text { (2015) (public) }\end{array}$ & $\begin{array}{l}\text { Panel (1995- } \\
\text { 2011) }\end{array}$ & Correlation & $\begin{array}{l}\text { Higher energy prices are } \\
\text { associated with a small but } \\
\text { significant decrease in } \\
\text { total investment across } \\
\text { firms. However, total } \\
\text { investment increases in the } \\
\text { most energy intensive } \\
\text { sectors. Higher energy } \\
\text { prices are associated with } \\
\text { a negative effect on } \\
\text { domestic investment } \\
\text { independent of the energy } \\
\text { intensity, which the } \\
\text { authors interpret as an } \\
\text { indicator for increased } \\
\text { offshoring. }\end{array}$ \\
\hline
\end{tabular}




\begin{tabular}{|c|c|c|c|c|c|c|}
\hline $\begin{array}{l}\text { Garsous and } \\
\text { Kozluk, } \\
2017\end{array}$ & $\begin{array}{l}\text { Energy prices as a proxy } \\
\text { for environmental policy } \\
\text { stringency }\end{array}$ & $\begin{array}{l}\text { Foreign Direct } \\
\text { Investment (FDI) } \\
\text { (measured as the } \\
\text { international-to- } \\
\text { total assets ratio) }\end{array}$ & $\begin{array}{l}6806 \text { publicly listed firms } \\
\text { from } 23 \text { OECD countries } \\
\text { and } 9 \text { industries } \\
\text { Financial variables from } \\
\text { Worldscope (commercial), } \\
\text { Energy Price index from } \\
\text { Sato et al. (2015) (public) }\end{array}$ & $\begin{array}{l}\text { Panel (1995- } \\
\text { 2011) }\end{array}$ & Correlation & $\begin{array}{l}\text { The effect of higher } \\
\text { domestic energy prices is } \\
\text { positively associated with } \\
\text { firms outward stock of } \\
\text { FDI, but small in } \\
\text { magnitude. The effect is } \\
\text { driven by more permanent } \\
\text { shocks to energy prices. }\end{array}$ \\
\hline
\end{tabular}




\begin{tabular}{|c|c|c|c|c|c|c|}
\hline $\begin{array}{l}\text { Ahmadi, } \\
2017\end{array}$ & $\begin{array}{l}\text { Plant-level GHG } \\
\text { emissions, emissions } \\
\text { intensity }\end{array}$ & $\begin{array}{l}\text { Plant-level } \\
\text { production output }\end{array}$ & $\begin{array}{l}24,200 \text { plant-years for } \\
\text { triple difference, } 35,227 \\
\text { plant-years for DiD. } \\
\text { Canadian Annual Survey of } \\
\text { Manufacturing (licence) } \\
\text { for plant level data (fuel } \\
\text { purchases, shipment } \\
\text { destinations, sales, final } \\
\text { products, plant location, } \\
\text { plant total production } \\
\text { costs). Fuel prices } \\
\text { collected for cities and } \\
\text { provinces to estimate } \\
\text { plant-level fuel quantities. } \\
\text { Embodied GHG emissions } \\
\text { by fuel-type to estimate } \\
\text { GHG emissions. Fuel prices } \\
\text { are from Natural } \\
\text { Resources Canada and } \\
\text { Statistics Canada (public). }\end{array}$ & $\begin{array}{l}\text { Panel (2004- } \\
\text { 2012) }\end{array}$ & Causation & $\begin{array}{l}\text { Using a DiD approach the } \\
\text { author finds a significant } \\
8 \% \text { reduction in } \mathrm{CO}_{2} \\
\text { emissions from the British } \\
\text { Columbia carbon tax. Yet, } \\
\text { the triple difference } \\
\text { method results in non- } \\
\text { significant } 2 \% \text { reduction. } \\
\text { The author concludes that } \\
\text { the BC carbon tax had } \\
\text { zero to little negative } \\
\text { effect on plants' GHG } \\
\text { emissions in British } \\
\text { Columbia. Yet, they find } \\
\text { that plants' output levels } \\
\text { increased and the } \\
\text { emissions intensity } \\
\text { declined by about } 7 \% \text {. } \\
\text { They attribute this finding } \\
\text { to the unique design and } \\
\text { the revenue neutrality of } \\
\text { the tax. }\end{array}$ \\
\hline
\end{tabular}




\begin{tabular}{|c|c|c|c|c|c|c|}
\hline $\begin{array}{l}\text { Walker, } \\
2011\end{array}$ & $\begin{array}{l}\text { Plant-level Clean Air Act } \\
\text { regulatory status (proxy } \\
\text { for plant-level } \\
\text { environmental } \\
\text { performance) }\end{array}$ & $\begin{array}{l}\text { Employment } \\
\text { levels and } \\
\text { employment } \\
\text { growth. }\end{array}$ & $\begin{array}{l}470,958 \text { plants in } \\
\text { Manufacturing and Utility } \\
\text { sectors } \\
\text { Census Bureau } \\
\text { Longitudinal Business } \\
\text { Database (LBD) (licence) } \\
\text { for employment, } \\
\text { payroll, firm age, } \\
\text { entry/exit at the } \\
\text { establishment level. Air } \\
\text { Facility Subsystem for } \\
\text { plant regulatory and } \\
\text { permit data (licence) }\end{array}$ & $\begin{array}{l}\text { Panel (1985- } \\
2005)\end{array}$ & Correlation & $\begin{array}{l}\text { Plant-level non- } \\
\text { attainment designation is } \\
\text { associated with a decline } \\
\text { in plant-level employment } \\
\text { growth. }\end{array}$ \\
\hline \multicolumn{7}{|c|}{ 3.3 The joint impact of environmental regulations on environmental and economic performance } \\
\hline $\begin{array}{l}\text { List et al., } \\
2003\end{array}$ & $\begin{array}{l}\text { Air pollution (Nitrogen } \\
\text { oxide and volatile } \\
\text { organic compounds as } \\
\text { the primary chemical } \\
\text { precursors to ozone). }\end{array}$ & $\begin{array}{l}\text { Plant location } \\
\text { (openings, closing, } \\
\text { expansions, } \\
\text { contractions). }\end{array}$ & $\begin{array}{l}280 \text { pollution-intensive } \\
\text { plants across the } 62 \\
\text { counties in New York } \\
\text { State. } \\
\text { Industrial Migration File } \\
\text { that was maintained by the } \\
\text { New York State } \\
\text { Department of Economic } \\
\text { Development (licence). }\end{array}$ & $\begin{array}{l}\text { Panel (1980- } \\
\text { 1990). }\end{array}$ & Causation & $\begin{array}{l}\text { Pollution-intensive plants } \\
\text { respond adversely to more } \\
\text { stringent environmental } \\
\text { regulation. }\end{array}$ \\
\hline
\end{tabular}


France

\begin{tabular}{|c|c|c|c|c|c|c|}
\hline $\begin{array}{l}\text { Wagner et } \\
\text { al., } 2014\end{array}$ & $\begin{array}{l}\text { Greenhouse Gas } \\
\text { Emissions, Carbon } \\
\text { Intensity. }\end{array}$ & Employment. & $\begin{array}{l}9500 \text { French } \\
\text { manufacturing firms } \\
\text { (approximately } 12.000 \\
\text { establishments) with more } \\
\text { than } 20 \text { employees. } \\
\text { EACEI (Annual survey of } \\
\text { energy consumptions in } \\
\text { the industry) for energy } \\
\text { consumption, French } \\
\text { annual business survey } \\
\text { (Enquete Annuelle des } \\
\text { Entreprise) (licence) for } \\
\text { balance sheet data, ETS } \\
\text { transaction log for } \\
\text { emissions allowances } \\
\text { (public). }\end{array}$ & $\begin{array}{l}\text { Panel (1999- } \\
\text { 2010). }\end{array}$ & Causation & $\begin{array}{l}\text { French manufacturing } \\
\text { plants regulated under the } \\
\text { EU ETS reduced carbon } \\
\text { emissions by } 15 \% \text { during } \\
\text { Phase II (2008-2013) } \\
\text { compared to unregulated } \\
\text { plants. No effect has been } \\
\text { found during Phase I } \\
\text { (2005-2007). They do not } \\
\text { find significant impacts on } \\
\text { employment or on } \\
\text { emission reallocation. } \\
\text { Reductions in emissions } \\
\text { appear to be largely driven } \\
\text { by reductions in the } \\
\text { carbon-intensity of } \\
\text { production. }\end{array}$ \\
\hline \multicolumn{7}{|c|}{ Germany } \\
\hline $\begin{array}{l}\text { Petrick and } \\
\text { Wagner, } \\
2014\end{array}$ & $\begin{array}{l}\text { Carbon emissions and } \\
\text { carbon intensity. }\end{array}$ & $\begin{array}{l}\text { Employment, } \\
\text { turnover, exports. }\end{array}$ & $\begin{array}{l}1658 \text { German } \\
\text { manufacturing facilities } \\
\text { with more than } 20 \\
\text { employees. } \\
\text { AFiD-Betriebspanel from } \\
\text { German Research Data } \\
\text { Centre (licence), CITL for } \\
\text { list of treated plants, } \\
\text { AMADEUS (commercial). }\end{array}$ & $\begin{array}{l}\text { Panel (2007- } \\
\text { 2010). }\end{array}$ & Causation & $\begin{array}{l}\text { The EU ETS caused } \\
\text { treated firms (firms that } \\
\text { were regulated by the EU } \\
\text { ETS) to reduce their } \\
\text { emissions by } 25 \text { to } 28 \\
\text { percentage points more } \\
\text { than non-treated firms } \\
\text { (non-regulated firms } \\
\text { which were otherwise } \\
\text { similar). The carbon } \\
\text { intensity of treated firms } \\
\text { declined between } 18 \text { and } \\
30 \text { percentage points faster } \\
\text { for EU ETS firms relative } \\
\text { to control firms. Firms } \\
\text { largely reduced their }\end{array}$ \\
\hline
\end{tabular}




\begin{tabular}{|l|l|l|l|l|}
\hline & & & & $\begin{array}{l}\text { carbon emissions by } \\
\text { switching from high- } \\
\text { carbon fuels to low-carbon } \\
\text { fuels. The authors find no } \\
\text { evidence that being } \\
\text { regulated under the EU } \\
\text { ETS had a negative impact } \\
\text { on employment. The } \\
\text { authors estimate that the } \\
\text { EU ETS increased gross } \\
\text { output between } 4 \text { and } 7 \\
\text { percent for regulated firms } \\
\text { compared to non-regulated } \\
\text { firms. The evidence } \\
\text { suggests that firms } \\
\text { responded to the EU ETS } \\
\text { regulation by reducing } \\
\text { their carbon intensity and } \\
\text { not by reducing the scale } \\
\text { of their production. }\end{array}$ \\
\hline
\end{tabular}




\begin{tabular}{|c|c|c|c|c|c|c|}
\hline \multicolumn{7}{|c|}{ Norway } \\
\hline $\begin{array}{l}\text { Klemetsen } \\
\text { et al., } 2016\end{array}$ & $\begin{array}{l}\text { Air pollutants }\left(\mathrm{CO}_{2},\right. \\
\mathrm{N}_{2} \mathrm{O} \text {, PFCs) all } \\
\text { measured in } \mathrm{CO}_{2} \\
\text { equivalents, Emissions } \\
\text { Intensity (emissions } \\
\text { divided by man hours), } \\
\text { Emissions Level. }\end{array}$ & $\begin{array}{l}\text { Value added at } \\
\text { factor prices, } \\
\text { labour } \\
\text { productivity. }\end{array}$ & $\begin{array}{l}152 \text { Norwegian plants, of } \\
\text { which } 72 \text { plants are } \\
\text { regulated by the EU ETS. } \\
\text { Annual emissions of } \\
\text { Norwegian plants from the } \\
\text { Norwegian Environment } \\
\text { Agency (licence), } \\
\text { Statistics Norway for plant } \\
\text { level data on employment, } \\
\text { value added, energy use } \\
\text { and prices (licence). }\end{array}$ & $\begin{array}{l}\text { Panel (2001- } \\
\text { 2013). }\end{array}$ & $\begin{array}{l}\text { Causation (yet } \\
\text { there remain } \\
\text { differences in } \\
\text { treatment and } \\
\text { control group } \\
\text { after } \\
\text { matching). }\end{array}$ & $\begin{array}{l}\text { Plants regulated under the } \\
\text { EU ETS reduced } \\
\text { emissions by } 30 \% \text { in } \\
\text { Phase II of the EU ETS, } \\
\text { but not in the other phases. } \\
\text { Plants did not reduce their } \\
\text { emissions intensity in any } \\
\text { phase. The authors find } \\
\text { positive effects on value } \\
\text { added and labour } \\
\text { productivity for plants } \\
\text { regulated under the EU } \\
\text { ETS compared to the } \\
\text { control group. }\end{array}$ \\
\hline \multicolumn{7}{|c|}{ Lithuania } \\
\hline $\begin{array}{l}\text { Jaraite and } \\
\text { Di Maria, } \\
2016\end{array}$ & $\begin{array}{l}\mathrm{CO}_{2} \text { emissions, } \mathrm{CO}_{2} \\
\text { intensity. }\end{array}$ & $\begin{array}{l}\text { Profitability, } \\
\text { Investment. }\end{array}$ & $\begin{array}{l}353 \text { Lithuanian firms (41 } \\
\text { ETS firms, } 312 \text { non-ETS } \\
\text { firms). } \\
\text { Sample survey of non- } \\
\text { financial enterprises (F-01) } \\
\text { from Statistics Lithuania } \\
\text { for main financial } \\
\text { indicators (licence). EU } \\
\text { CITL for emissions data } \\
\text { (public). }\end{array}$ & $\begin{array}{l}\text { Panel (2005- } \\
\text { 2010). }\end{array}$ & Causation & $\begin{array}{l}\text { During Phase I the EU } \\
\text { ETS did not cause a } \\
\text { reduction in } \mathrm{CO}_{2} \\
\text { emissions. Yet, } \mathrm{CO}_{2} \\
\text { intensity decreased } \\
\text { slightly between } 2006 \text { and } \\
\text { 2007. They find no } \\
\text { significant effect on firm } \\
\text { profitability from the EU } \\
\text { ETS. Yet, the authors } \\
\text { suggest that the EU ETS } \\
\text { might have induced the } \\
\text { retirement of old and less } \\
\text { efficient capital stock } \\
\text { during Phase I, and led to } \\
\text { some additional } \\
\text { investments into new } \\
\text { capital equipment from } \\
\text { 2010. }\end{array}$ \\
\hline
\end{tabular}


Pan-European studies

\begin{tabular}{|c|c|c|c|c|c|c|}
\hline $\begin{array}{l}\text { Abrell et al., } \\
2011\end{array}$ & $\mathrm{CO}_{2}$ emissions. & $\begin{array}{l}\text { Profits, } \\
\text { employment, } \\
\text { value added. }\end{array}$ & $\begin{array}{l}2101 \text { European firms. } \\
\text { Community Independent } \\
\text { Transaction Log (CITL) } \\
\text { collected by the European } \\
\text { Commission for emission } \\
\text { allowances (public), } \\
\text { AMADEUS for firm } \\
\text { production data } \\
\text { (commercial). }\end{array}$ & $\begin{array}{l}\text { Panel (2005- } \\
\text { 2008). }\end{array}$ & Causation & $\begin{array}{l}\text { Emission reductions were } \\
3.6 \% \text { higher between } 2007 \\
\text { and } 2008 \text { than between } \\
2005 \text { and } 2006 \text {, which the } \\
\text { authors attribute to the } \\
\text { increased stringency of the } \\
\text { regulation of the EU ETS. } \\
\text { They argue that the shift } \\
\text { from Phase I to Phase II of } \\
\text { the EU ETS had a } \\
\text { significant impact on } \\
\text { firms' emission reductions. } \\
\text { They find that the EU ETS } \\
\text { did at most modestly } \\
\text { affect profits, employment } \\
\text { and value added of } \\
\text { regulated firms. This study } \\
\text { finds a causal effect, yet } \\
\text { they take control firms } \\
\text { only from non-regulated } \\
\text { sectors, which likely } \\
\text { introduce a selection bias } \\
\text { at the sector level). }\end{array}$ \\
\hline \multicolumn{7}{|c|}{ 3.3.2: The joint impact of the UK Climate Change Levy on carbon emissions and firm performance } \\
\hline $\begin{array}{l}\text { Martin et } \\
\text { al., 2014a }\end{array}$ & $\begin{array}{l}\text { Energy intensity, } \\
\text { electricity use. }\end{array}$ & $\begin{array}{l}\text { Employment, } \\
\text { Revenue, Total } \\
\text { factor } \\
\text { productivity, plant } \\
\text { exit. }\end{array}$ & $\begin{array}{l}6886 \text { UK plants. } \\
\text { Annual respondents } \\
\text { database (ARD) which is } \\
\text { maintained by the Office } \\
\text { for National Statistics } \\
\text { (licence), Quarterly Fuels } \\
\text { Inquiry (QFI) for energy } \\
\text { use information, } \\
\text { information on CCA }\end{array}$ & $\begin{array}{l}\text { Panel (2001- } \\
\text { 2004). }\end{array}$ & Causation & $\begin{array}{l}\text { The UK Climate Change } \\
\text { Levy had a strong } \\
\text { negative impact on energy } \\
\text { intensity (-18\%) and } \\
\text { electricity use }(-22.6 \%) \text {. } \\
\text { No statistically significant } \\
\text { impacts are found for } \\
\text { employment, revenue, } \\
\text { total factor productivity or } \\
\text { plant exit. The results }\end{array}$ \\
\hline
\end{tabular}




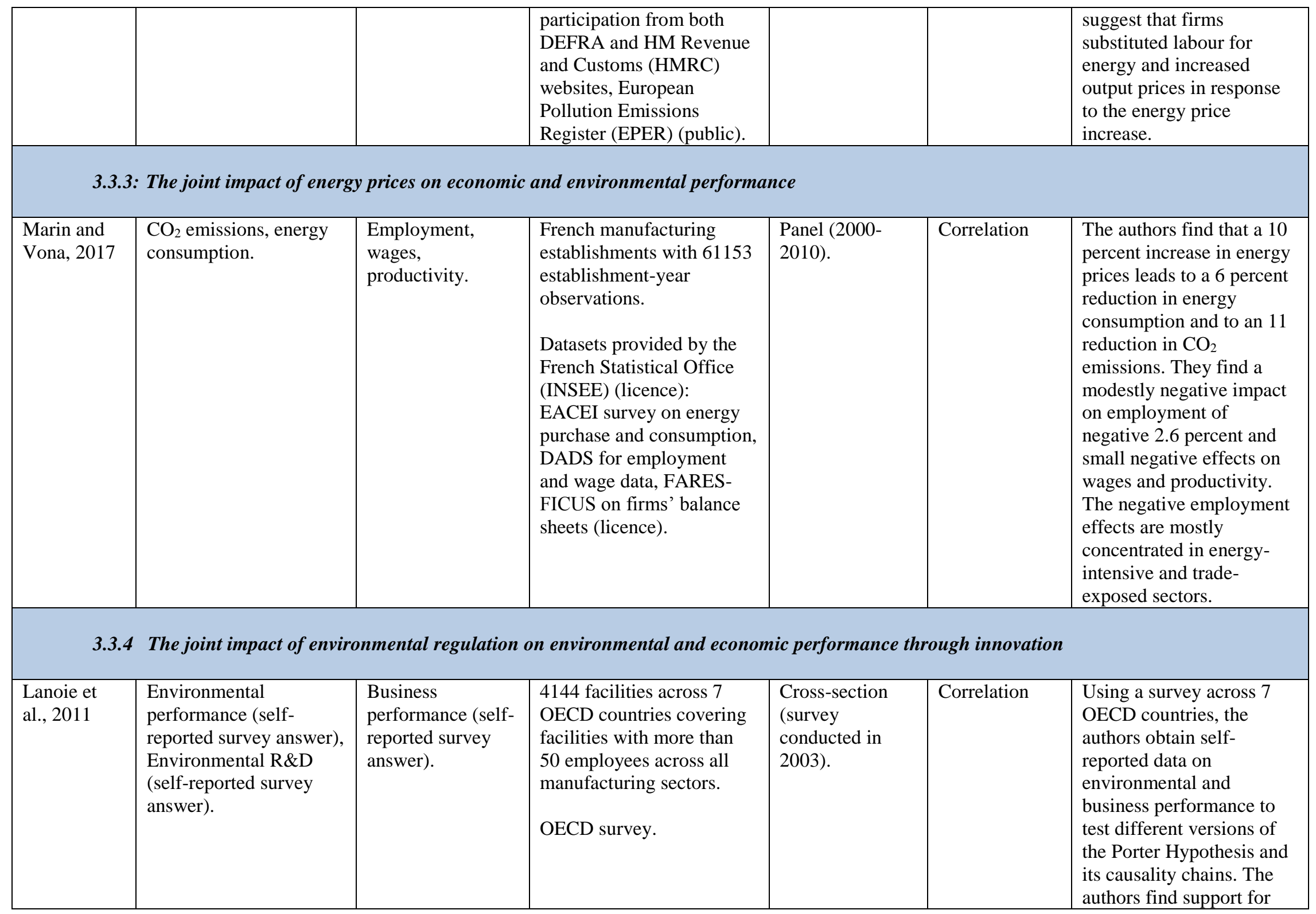




\begin{tabular}{|c|c|c|c|c|c|c|}
\hline & & & & & & $\begin{array}{l}\text { the "weak" version of the } \\
\text { Porter Hypothesis, } \\
\text { showing that } \\
\text { environmental regulation } \\
\text { induces innovation. } \\
\text { Furthermore, they also } \\
\text { find that more flexible } \\
\text { "performance standards" } \\
\text { are more likely to induce } \\
\text { innovation than more } \\
\text { prescriptive "technology- } \\
\text { based standards". Yet, } \\
\text { they find no support for } \\
\text { the "strong" version of the } \\
\text { Porter Hypothesis. They } \\
\text { find a negative direct } \\
\text { effect of policy stringency } \\
\text { on business performance, } \\
\text { which exceeds the indirect } \\
\text { positive effect, mediated } \\
\text { through R\&D. }\end{array}$ \\
\hline $\begin{array}{l}\text { Rexhauser } \\
\text { and } \\
\text { Rammer, } \\
2014\end{array}$ & $\begin{array}{l}\text { Environmental } \\
\text { Innovation (Defined as a } \\
\text { new or significantly new } \\
\text { product introduced } \\
\text { between } 2006 \text { and } 2008 \\
\text { in the firm that creates } \\
\text { environmental benefits } \\
\text { compared to } \\
\text { alternatives; self- } \\
\text { reported). }\end{array}$ & Firm profitability. & $\begin{array}{l}3618 \text { German firms. } \\
\text { German part of the } \\
\text { Community Innovation } \\
\text { survey (Mannheim } \\
\text { innovation panel) } \\
\text { (licence). }\end{array}$ & $\begin{array}{l}\text { Cross-section } \\
\text { (Survey } \\
\text { conducted in } \\
2009 \text { ). }\end{array}$ & Correlation & $\begin{array}{l}\text { The authors provide } \\
\text { evidence that } \\
\text { environmental innovation, } \\
\text { which improves firms' } \\
\text { resource efficiency, can } \\
\text { provide positive } \\
\text { profitability effects. Yet, } \\
\text { for any other } \\
\text { environmental innovation, } \\
\text { which does not improve } \\
\text { resource efficiency, they } \\
\text { find some weak evidence } \\
\text { for adverse profitability } \\
\text { effects. }\end{array}$ \\
\hline
\end{tabular}


